\title{
HYDROLOGY OF AREA 22, EASTERN COAL PROVINCE, ALABAMA
}

- MULBERRY FORK

- LOCUST FORK

- SIPSEY FORK

- BEAR CREEK
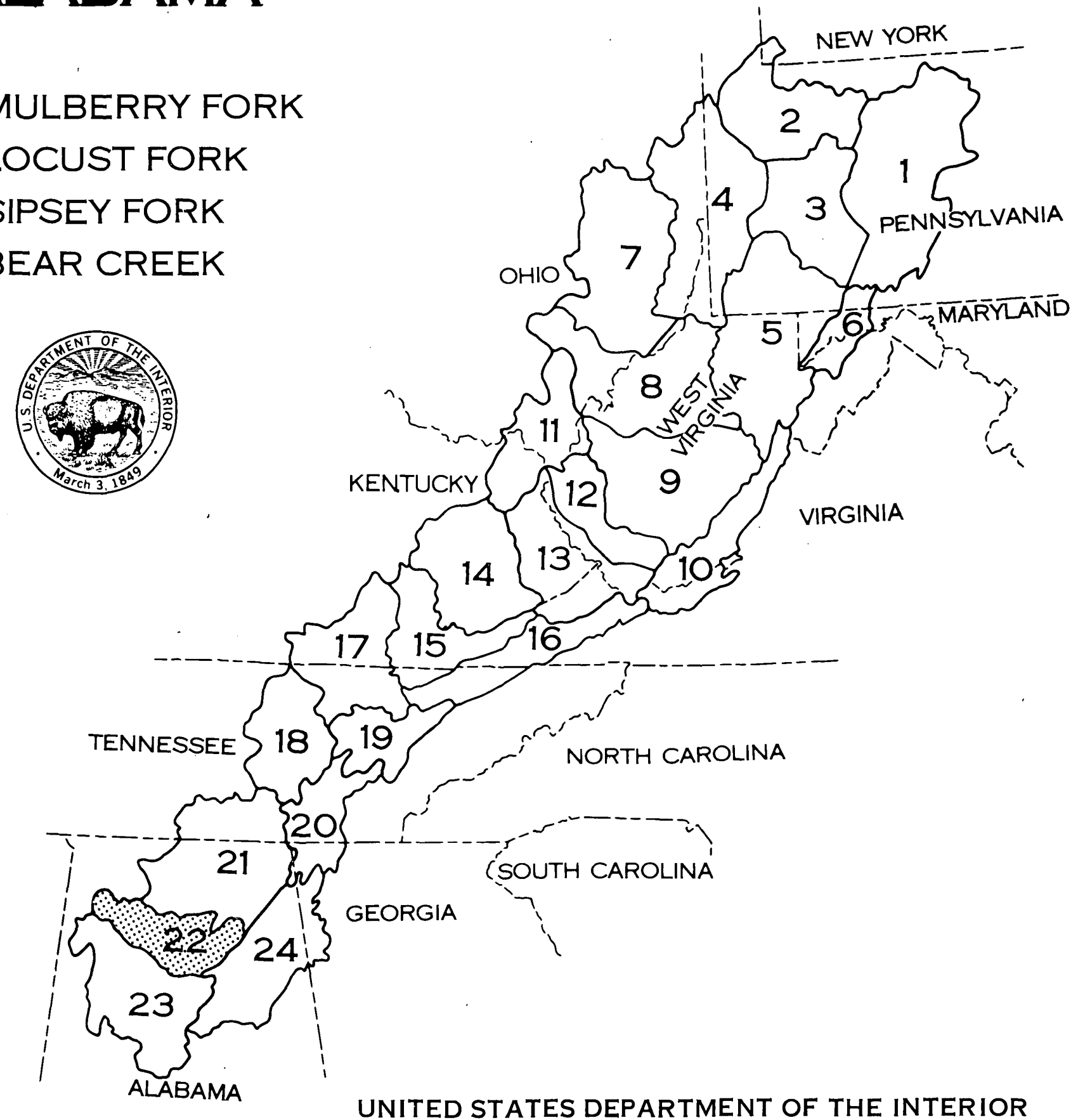

UNITED STATES DEPARTMENT OF THE INTERIOR GEOLOGICAL SURVEY 


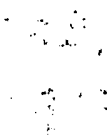

. . 


\section{HYDROLOGY OF AREA 22, EASTERN COAL PROVINCE, ALABAMA}

BY

JOE R. HARKINS AND OTHERS

U. S. GEOLOGICAL SURVEY

WATER-RESOURCES INVESTIGATIONS 81-135

TUSCALOOSA, ALABAMA

MARCH 1981 


\section{UNITED STATES DEPARTMENT OF THE INTERIOR}

JAMES G. WATT, Secretary

\section{GEOLOGICAL SURVEY}

Doyle G. Frederick, Acting Director

For additional information write to:

U. S. Geological Survey

P. O. Box V

University, Alabama 35486 


\section{CONTENTS}

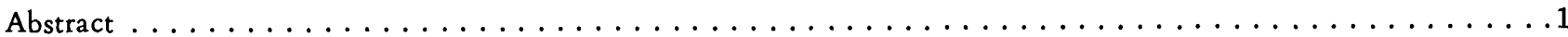

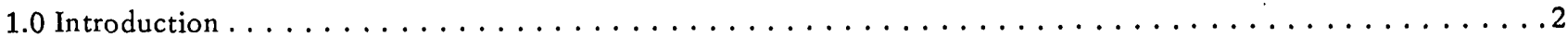

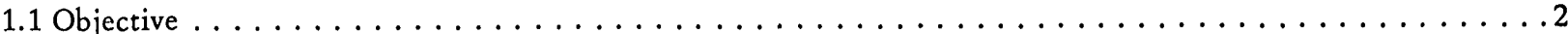

F. A. Kilpatrick and J. R. Rollo

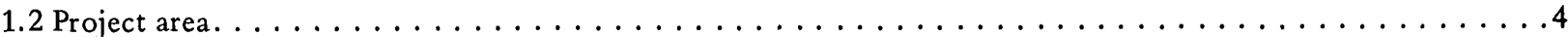
Joe R. Harkins

1.3 Hydrologic problems related to surface mining. . . . . . . . . . . . . . . . . . . .6 Celso Puente

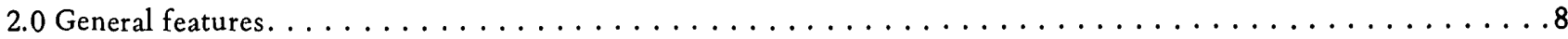

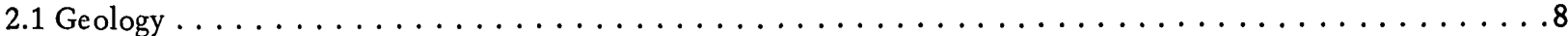
A. K. Sparkes

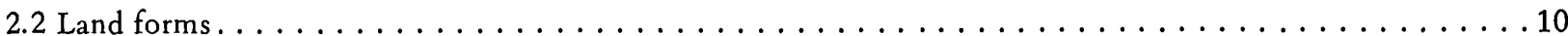
A. K. Sparkes

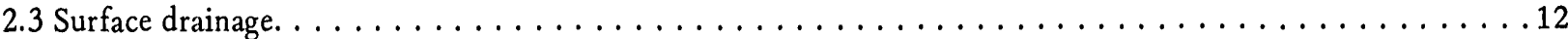
Joe R. Harkins

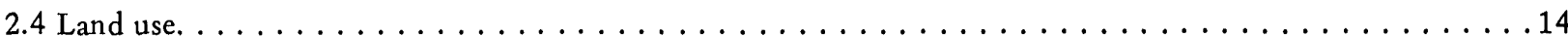
G. J. Allord

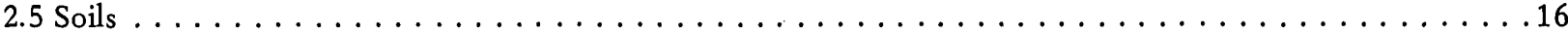
Mark E. Green

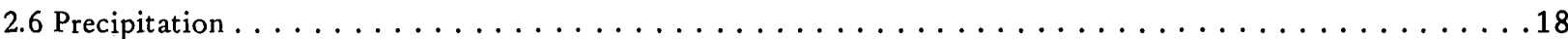
Joe R. Harkins

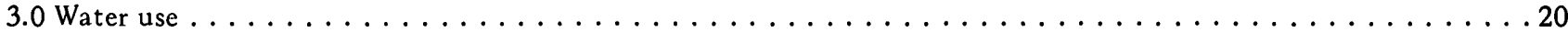

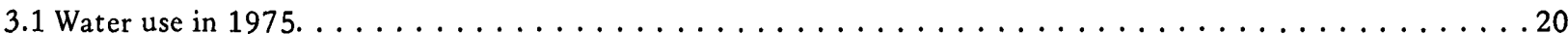
Mark E. Green

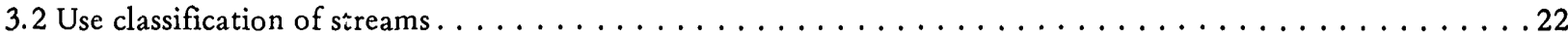
Mark E. Green

4.0 Hydrologic networks. . . . . . . . . . . . . . . . . . . . . . . . . . 24

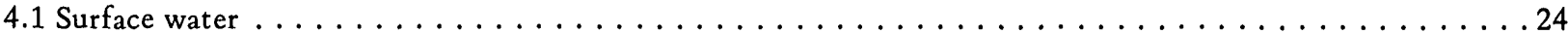
Joe R. Harkins

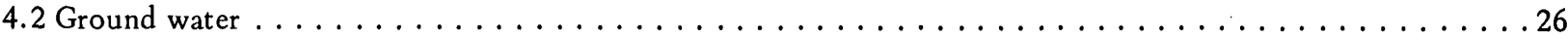
A. K. Sparkes

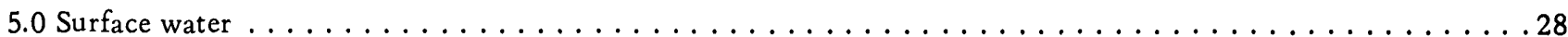

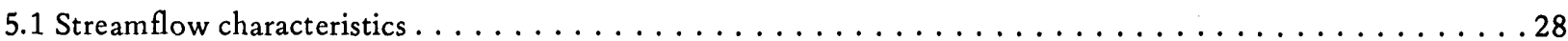
Joe R. Harkins

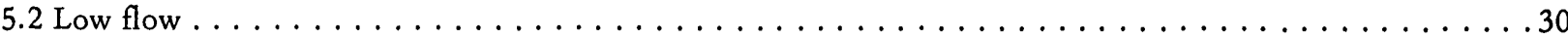
Joe R. Harkins

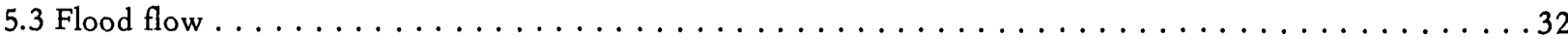
Joe R. Harkins

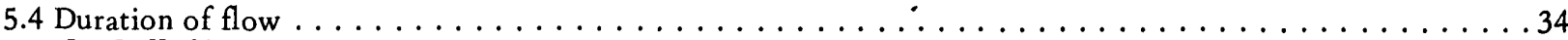
Joe R. Harkins 


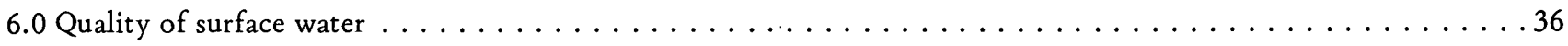

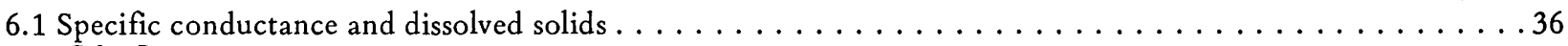
Celso Puente

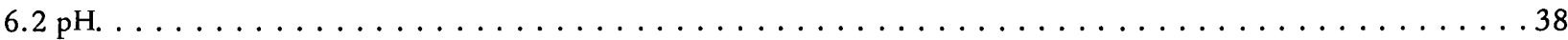
Celso Puente

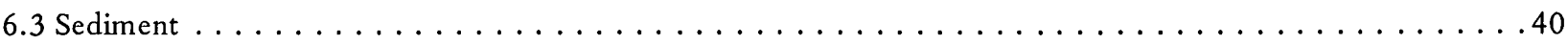
Celso Puente

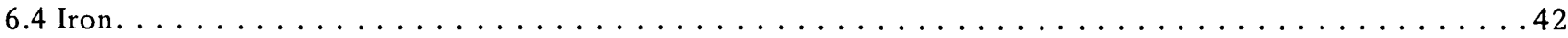
Elizabeth A. Flanary

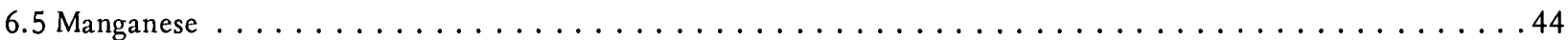
Elizabeth A. Flanary

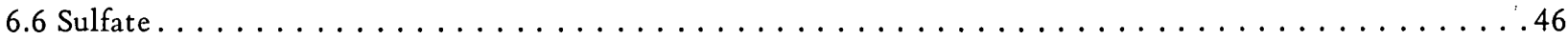
Celso Puente

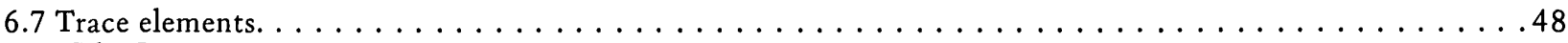
Celso Puente

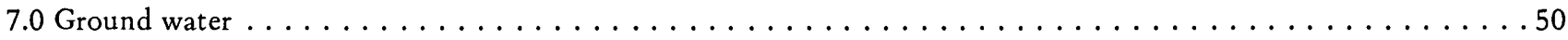

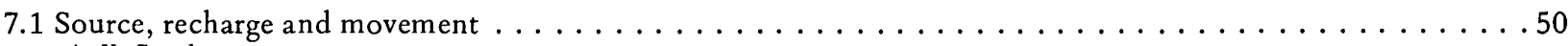
A. K. Sparkes

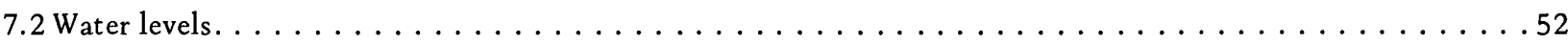
A. K. Sparkes

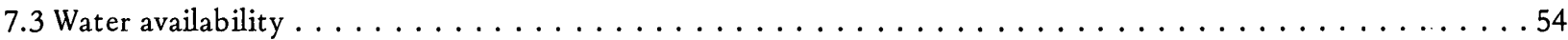
A. K. Sparkes

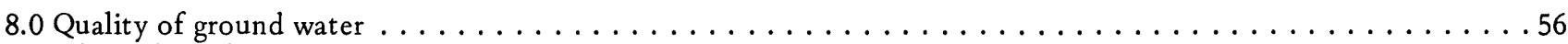
Elizabeth A. Flanary

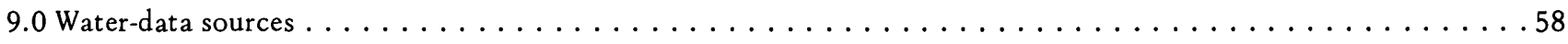

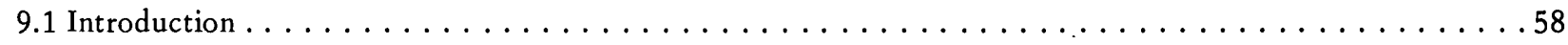

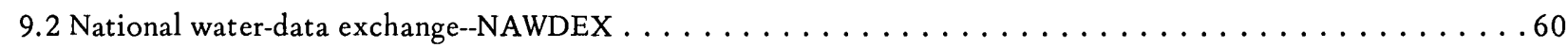

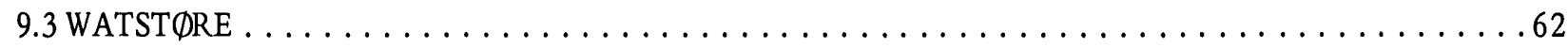

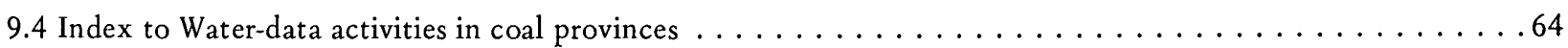

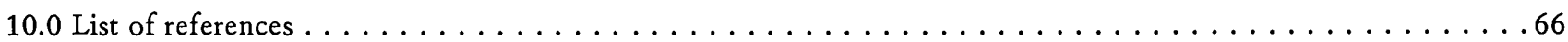

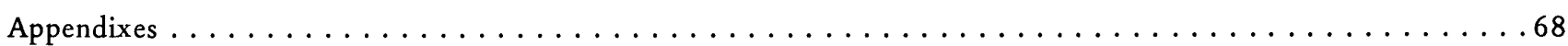

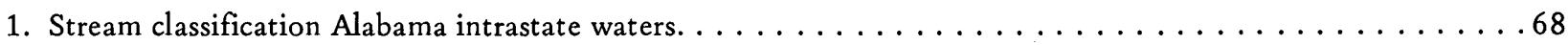

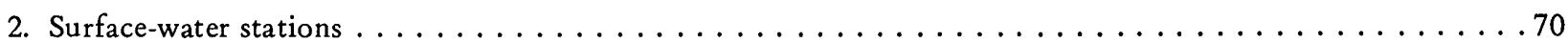

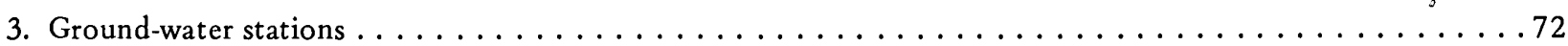




\section{FACTORS FOR CONVERTING INCH-POUND UNITS TO INTERNATIONAL SYSTEM OF UNITS (SI)}

For the convenience of readers who may want to use International System of Units (SI), the data may be converted by using the following factors:

\begin{tabular}{|c|c|c|}
\hline Multiply the inch-pound units & By & To obtain the SI units \\
\hline inches (in) & 25.4 & millimeters (mm) \\
\hline inches per hour (in/h) & $\begin{array}{c}25.4 \\
2.54\end{array}$ & $\begin{array}{l}\text { millimeters per hour }(\mathrm{mm} / \mathrm{h}) \\
\text { centimeters per hour }(\mathrm{cm} / \mathrm{h})\end{array}$ \\
\hline feet $(\mathrm{ft})$ & 0.3048 & meters $(\mathrm{m})$ \\
\hline feet per mile (ft/mi) & 0.1894 & meters per kilometer $(\mathrm{m} / \mathrm{km})$ \\
\hline miles (mi) & 1.609 & kilometers (km) \\
\hline square miles $\left(\mathrm{mi}^{2}\right)$ & 2.590 & square kilometers $\left(\mathrm{km}^{2}\right)$ \\
\hline acre & 0.4047 & square hectometers $\left(\mathrm{hm}^{2}\right)$ \\
\hline acre feet & 1233 & cubic meters $\left(\mathrm{m}^{3}\right)$ \\
\hline gallons per minute (gal/min) & 0.06309 & liters per second $(\mathrm{L} / \mathrm{s})$ \\
\hline million gallons per day (mgal/d) & $\begin{array}{l}0.04381 \\
3785\end{array}$ & $\begin{array}{l}\text { cubic meters per second }\left(\mathrm{m}^{3} / \mathrm{s}\right) \\
\text { cubic meters per day }\left(\mathrm{m}^{3} / \mathrm{d}\right)\end{array}$ \\
\hline cubic feet per second $(\mathrm{ft} 3 / \mathrm{s})$ & 0.02832 & cubic meters per second $\left(\mathrm{m}^{3} / \mathrm{s}\right)$ \\
\hline $\begin{array}{l}\text { cubic feet per second per } \\
\text { square mile }\left[\left(\mathrm{ft}^{3} / \mathrm{s}\right) / \mathrm{mi}^{2}\right]\end{array}$ & 0.01093 & $\begin{array}{l}\text { cubic meters per second per } \\
\text { square kilometer }\left[\left(\mathrm{m}^{3} / \mathrm{s}\right) / \mathrm{km}^{2}\right]\end{array}$ \\
\hline $\begin{array}{l}\text { tons per square mile per } \\
\text { year }\left[\left(\operatorname{ton} / \mathrm{mi}^{2}\right) / \mathrm{yr}\right]\end{array}$ & 0.03753 & $\begin{array}{l}\text { metric tons per square kilometer } \\
\text { per year }\left[\left(\mathrm{t} / \mathrm{km}^{2}\right) / \mathrm{yr}\right]\end{array}$ \\
\hline
\end{tabular}


' 


\title{
HYDROLOGY OF AREA 22, EASTERN COAL PROVINCE, ALABAMA
}

\author{
BY \\ JOE R. HARKINS AND OTHERS
}

\section{ABSTRACT}

The Eastern Coal Province is divided into 24 hydrologic reporting areas. Area 22 is located near the southern end of the Eastern Coal Province, in the Mobile and Tennessee River basins. It includes part of the Plateau and the northern edge of the Warrior coal fields in Alabama, and covers an area of 2,495 square miles.

This report is designed to be useful to mine owners and operators and consulting engineers by presenting information about existing hydrologic conditions and identifying sources of hydrologic information. General hydrologic information is presented in a brief text with illustrations on a single water-resources related topic.

The area is underlain by the Cretaceous Tuscaloosa Group (Gordo and Coker Formations), Pennsylvanian Pottsville Formation, and pre-Pennsylvanian rocks. The Pottsville Formation, containing the coal beds, underlies about 85 percent of the Area, including all of the central part. Pre-Pennsylvanian rocks are exposed in two valleys along the eastern side of the Area and the Tuscaloosa Group overlies the Pottsville Formation and the prePennsylvanian rocks along the western side.

The Area lies in four stream basins, the Mulberry and Locust Forks of the Black Warrior River and Bear Creek, which is a tributary to the Tennessee River. Sipsey Fork, the largest basin, is a tributary to Mulberry Fork. Mulberry Fork basin is underlain almost entirely by the coal-bearing rocks of the Pottsville Formation. Sipsey Fork, principal tributary to Mulberry Fork, and most of it's tributaries flow into Lewis Smith Lake. The outflow of the lake is regulated by hydropower generating turbines. Locust Fork drains the eastern side of the Area. It's basin contains part of two valleys of pre-Pennsylvanian rocks. Bear Creek and it's tributaries drain the western edge of the Area where the Tuscaloosa Group overlies the Pottsville Formation or the pre-Pennsylvanian rocks.

The Area has a moist temperate climate with an annual rainfall that ranges from 56 inches in the southern part to 52 inches along the western edge. The majority of the Area is covered by forest and the soils have a high erosion potential when vegetative cover is removed.
Use of water is primarily from surface-water sources as ground-water supplies generally are not sufficient for public supplies. The largest uses of water are for hydroelectric power generation, and industrial and municipal supplies for use outside the Area (Birmingham).

The U.S. Geological Survey operates a network of hydrologic data collection stations to monitor the streamflow and ground-water conditions. This network includes 74 surface-water stations, 13 observation wells, and 4 springs. These data include rate of flow, water levels, and water-quality parameters. These data are available from computer storage through the National Water Data Exchange (NAWDEX) as well as in published reports.

Hydrologic problems relating to surface mining are (1) erosion and sedimentation, (2) decline in groundwater levels, and (3) degradation of water quality. Average annual sediment yields can increase by four magnitudes in surface mined areas from 20 tons per square mile per year from areas not affected by mining to 300,000 tons per square mile per year from mined areas. Sediment yields increase drastically when vegetation is removed from the highly erosive soils and from unregulated surface mining operations. Decline in ground-water levels can occur in and near surface mining areas when excavation extends below the water level in the aquifer. This can cause nearby wells and springs to go dry. Acid mine drainage is a problem only adjacent to the mined area. The acid water is neutralized quickly by the buffering action of calcareous minerals and (or) alkaline water, but does increase trace-element concentrations including aluminum, copper, lead, iron, manganese, and zinc. Dissolved-iron concentrations which are high in and near surface mining areas rapidly decrease due to aeration and dilution as the water moves downstream and in short distances downstream are comparable with water from unmined areas. Sulfate is usually the major dissolved constituent in water from mined areas and tends to stay dissolved although its concentrations are reduced by dilution. Sulfate concentrations, like most water-quality parameters, are higher at times of low flow of streams. 


\subsection{INTRODUCTION 1.1 OBJECTIVE}

\section{Area 22 Report Submitted in Support of Public Law 95-87}

\section{Existing hydrologic conditions and identification of sources of hydrologic information are presented.}

This report provides broad hydrologic information, using a brief text on an accompanying map, chart, graph, or other illustrations for each of a series of waterresources related topics. The summation of the topical discussions provides a description of the hydrology of the area. The information contained herein should be useful to surface mine owners and operators, and consulting engineers in the preparation of permits and regulatory authorities in appraising the adequacy of permit applications.

A need for hydrologic information and analysis on a scale never before required nationally was initiated when the "Surface Mining Control and Reclamation Act of 1977" was signed into law as Public Law 95-87, August 3, 1977. The Act established a new Federal agency, Office of Surface Mining Reclamation and Enforcement (OSM), within the U.S. Department of the Interior, whose function is to set guidelines for controlling the adverse effects of coal mining on the environment. The Act provided for establishment of State-level regulatory authorities to administer and enforce State laws meeting the Federal guidelines. Further provided in the Act is the backup provision that if no satisfactory State program is developed the Federal regulations will be enforced by OSM.
In recognizing the potentially adverse impact that coal mining may have on water resources, Public Law 95-87 requires (1) that each mining-permit applicant make an analysis of the potential effects of the proposed mine on the hydrology of the mine site and adjacent area, (2) that "an appropriate Federal or State agency" provide to each mining-permit " and (3) that measures be taken by mining permittees to control adverse effects of mining on the "hydrologic balance" and reclamation of the land.

This report broadly characterizes the hydrology of Area 22 in Alabama as delineated in figure 1.1-1. The hydrologic information presented or available through sources identified in this report, may be used in describing the hydrology of the "general area" of any proposed mine. Furthermore, it is expected that this hydrologic information will be supplemented by the lease applicant's specific site data as well as data from other sources to provide a more detailed picture of the hydrology of the area in the vicinity of the mine and the anticipated hydrologic consequences of the mining operation. 


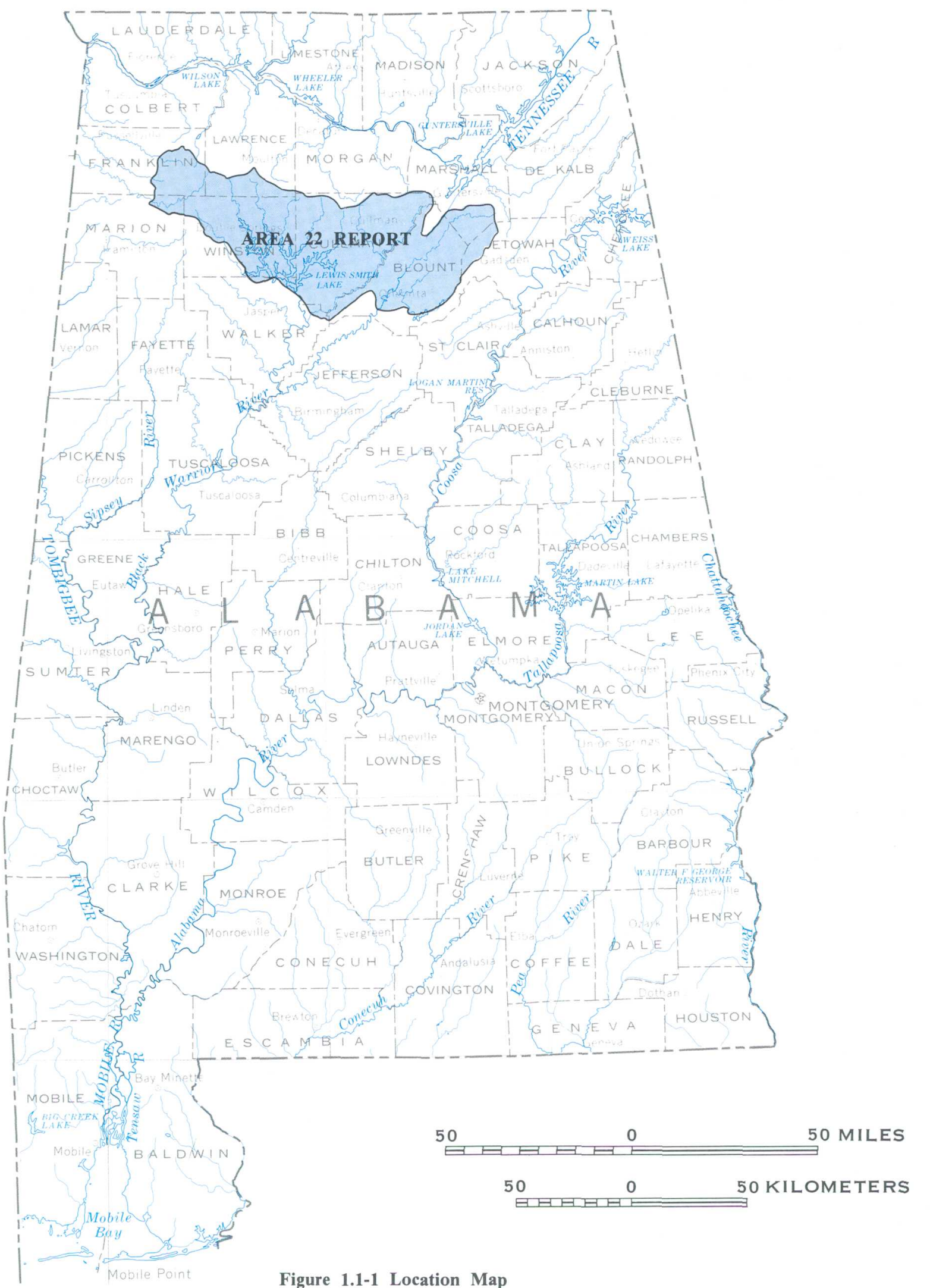

1.0 INTRODUCTION

1.1 OBJECTIVE 


\title{
1.0 INTRODUCTION (Continued) I.2 PROJECT AREA
}

\section{Area 22 is Located in Southern Part of Eastern Coal Province}

\author{
Area 22 includes 2495 square miles of which 2194 square \\ miles are in the Black Warrior River basin and 301 \\ square miles are in the Bear Creek basin.
}

The Eastern Coal province is divided into 24 hydrologic reporting areas. The division is based on hydrologic factors, location, size, and mining activity. Hydrologic units (drainage basins) or parts of units are combined to form each area (see front cover for areas in the Eastern Coal province). The drainage basins in Area 22 are shown in figure 1.2-1.

Area 22 is near the southern end of the Eastern Coal province in Alabama. The area, which includes parts of Etowah, Blount, Marshall, Cullman, Walker, Winston, Lawrence, Franklin, and Marion Counties, lies within the Mobile River basin except for the area in Franklin County, a small area in the western edges of Lawrence and Winston Counties, and the northern edge of Marion County which drain to the Tennessee River by way of Bear Creek.

Area 22 includes $2495 \mathrm{mi}^{2}$ and encompasses the upper part of the Black Warrior River basin and the headwater area for Bear Creek. It includes the basins of Locust and Mulberry Forks of the Black Warrior River from Trafford to the headwaters of Locust Fork and from Empire to the headwaters of Mulberry Fork. The basin of Sipsey Fork, a tributary to Mulberry Fork, is the largest single basin in Area 22 and contains Lewis Smith Lake with a surface area of $33.1 \mathrm{mi}^{2}(21,200$ acres). The mouth of the Sipsey Fork is also in Area 22. The headwater area of Bear Creek basin is drained by Bear Creek and two tributaries, Cedar and Little Bear Creeks.

Area 22 covers most of the southern end of the Plateau Coal Field and a small part of the Warrior Coal Field along the southern edge of the Area (fig. 1.2-2). The Area also includes the southern end of the Sequatchie Valley and almost all of Murphrees Valley. These valleys extend across the Area in a northeast-southwest direction across the eastern side and are not a part of the coal fields.

The Cumberland Plateau section of the Appalachian Plateaus province comprises most of Area 22 (fig. 1.2-3). The eastern half of Franklin County lies in three physiographic regions; the Highland Rim section of the Interior Low Plateaus province, the Cumberland Plateau section of the Appalachian Plateaus province, and East Gulf Coastal Plain of the Coastal Plain province. 

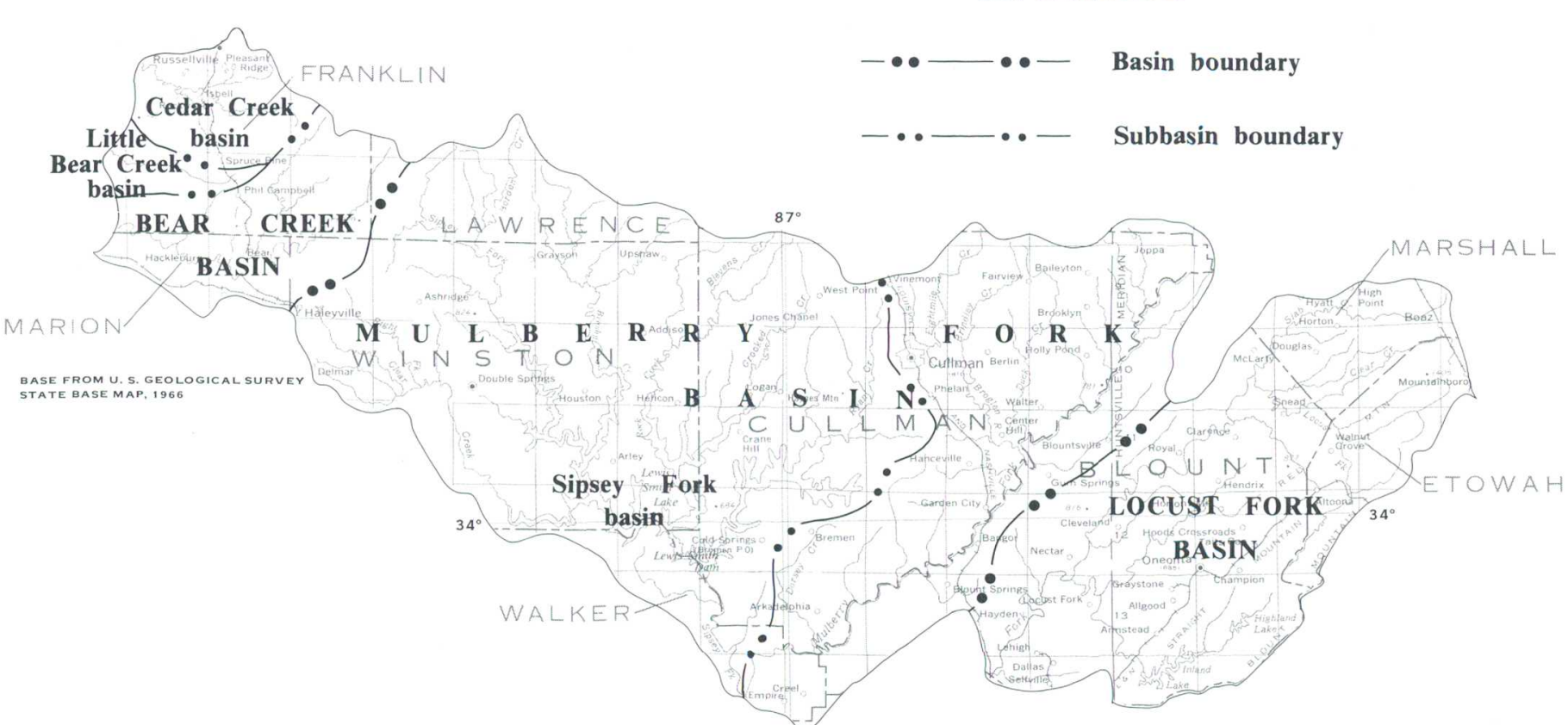

Figure 1.2-1 Drainage basins.

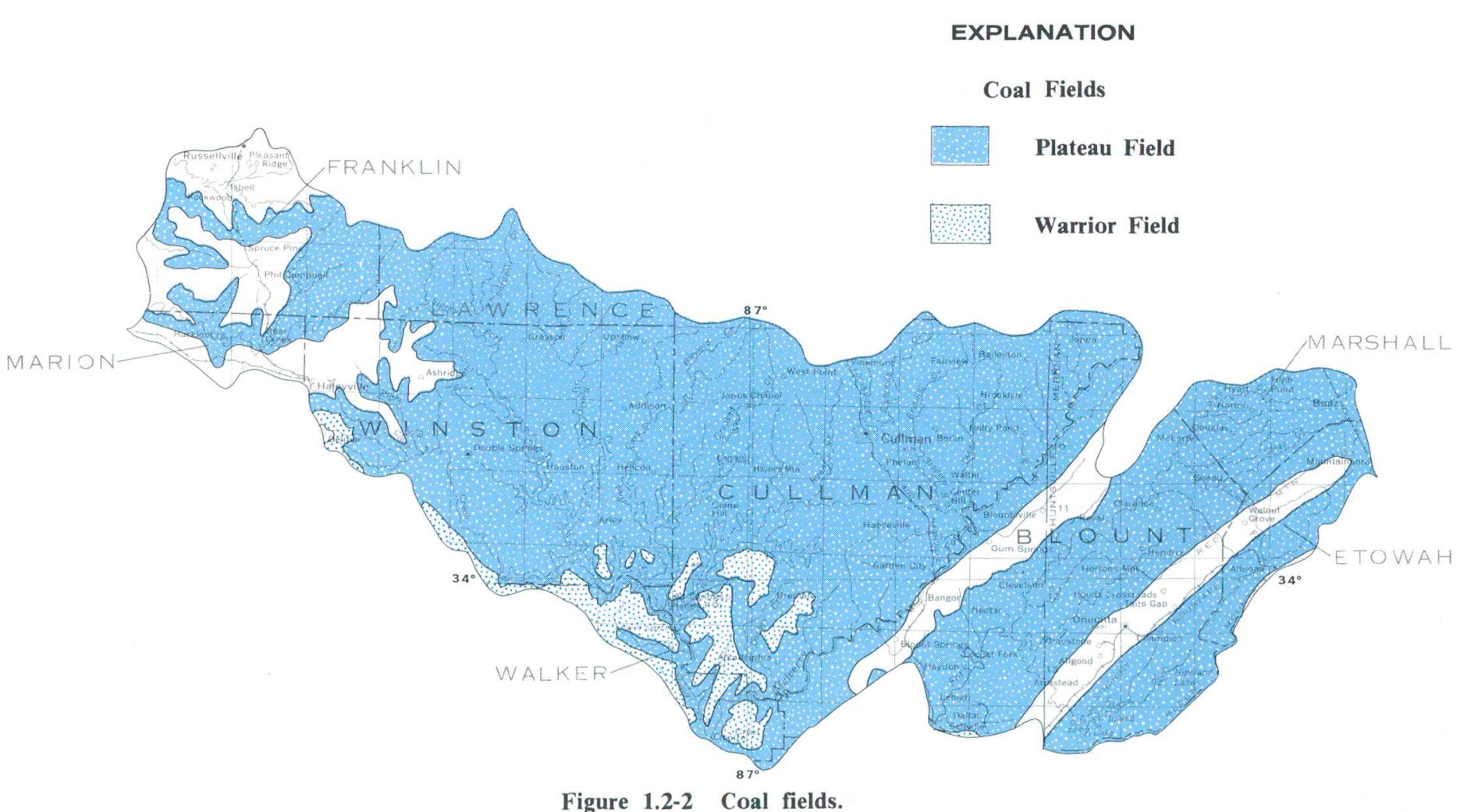

Figure 1.2-2 Coal fields.

\section{EXPLANATION}

Physiographic Divisions

Highland Rim section
(Interior Low Plateaus province)

Cumberland Plateau section

(Appalachian Plateaus province)

East Gulf Coastal Plain section

(Coastal Plain province)

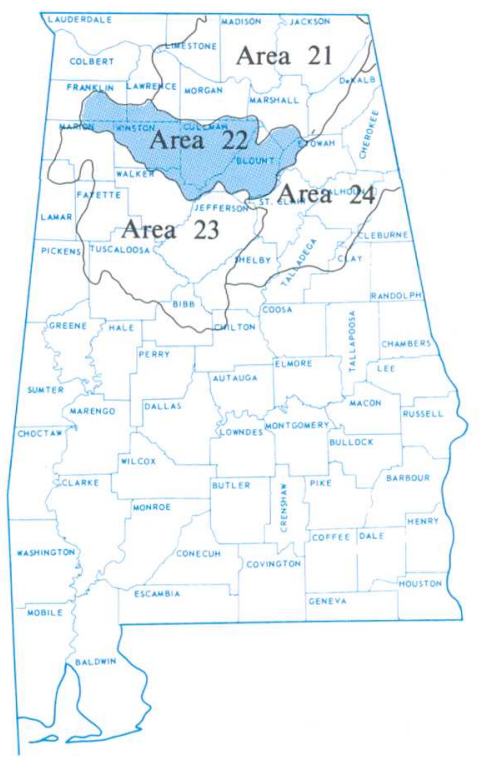

Location of Area 22 in Alabama

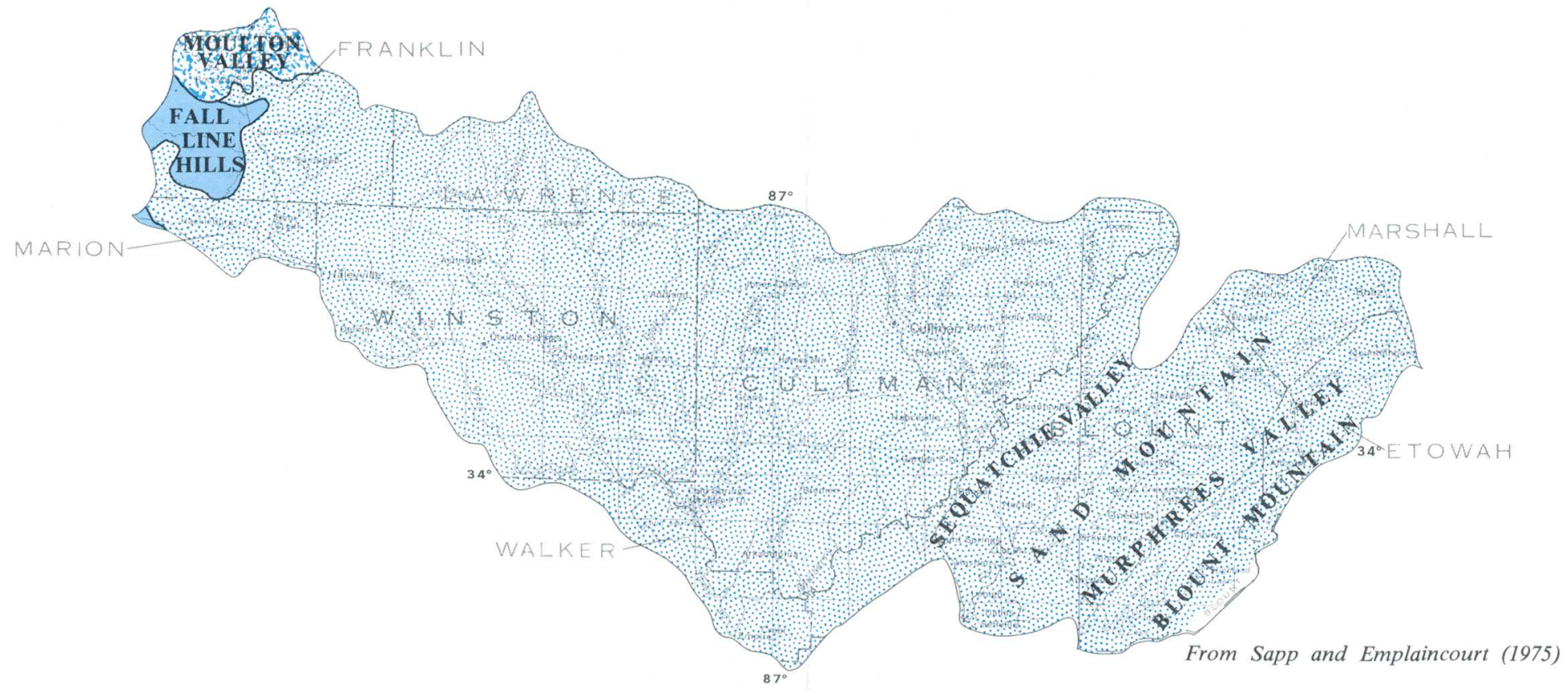

Figure 1.2-3 Physiographic divisions. 


\title{
1.0 INTRODUCTION (Continued) \\ 1.3 HYDROLOGIC PROBLEMS RELATED TO SURFACE MINING
}

\section{Hydrologic Environment can be Adversely Altered by Surface Coal Mining}

\author{
Erosion, sedimentation, decline in water levels, \\ diversion of drainage, and degradation of water \\ quality are typical problems associated with \\ surface coal mining.
}

\begin{abstract}
Surface mining drastically alters the environment of previously undisturbed lands and if the areas are unreclaimed there can be long-term detrimental environmental consequences. Mining activities such as the removal of vegetation, excavation, and creation of large volumes of unconsolidated spoil materials increases the potential for erosion and sedimentation (fig. 1.3-1). Average annual sediment yields for streams draining relatively undisturbed basins in Area 22 generally range from 20 to 800 (tons $/ \mathrm{mi}^{2}$ )/yr. In contrast, annual sediment yields for streams draining heavily mined but unreclaimed areas can be as high as 300,000 (tons $/ \mathrm{mi}^{2}$ )/yr (Hubbard, 1976).
\end{abstract}

Adverse effects generally associated with increased erosion include excessive sediment deposition in streams and reservoirs which in turn increases the cost of maintaining navigation channels and treating industrial and domestic water. Examples of extreme erosion and sediment deposition that have occurred in adjacent Area 23 are shown in figure 1.3-1. Sediment deposition in Locust Fork of the Black Warrior River near Sayre has resulted in an alteration of the aquatic habitat, increased flooding due to filling of the stream channel by sediment, and reduction of aesthetic value in recreation areas (fig. 1.3-1). Sediment deposition at Lake Harris, a municipal water-supply source for the city of Tuscaloosa, has reduced reservoir storage capacity (fig. 1.3-2).

Decline of ground-water levels can occur in and near surface-mining areas when excavation extends below the base water level of the basin. This can cause wells and springs to go dry. A hypothetical diagram illustrating water-level declines resulting from surface mining is shown in figure 1.3-3. The water level declines could be temporary or permanent depending on depth of excavation and subsequent reclamation.

The alteration of natural topography by surface mining commonly diverts drainage. Such diversion alters the streamflow characteristics (Knight and Newton, 1977). Diversion of drainage is illustrated by the hypothetical diagrams shown in fig. 1.34.

One of the most common and troublesome waterquality problems is acid-mine drainage. During mining, accelerated weathering of iron-bearing minerals (pyrite and marcasite) exposed in spoil materials and coal beds produces sulfuric acid and large quantities of soluble mineral salts. Water draining such a mined area generally has low $\mathrm{pH}$ values (2.5-5.0 units), high sulfate, and high dissolved-solids concentrations. The acidic water reacts with other minerals and commonly increases traceelement concentrations including aluminum, copper, lead, iron, manganese, and zinc. Adverse effects associated with acidic and highly mineralized mine drainage include: (1) reduction of stream aquatic life, (2) increased corrosiveness, (3) limited use of water for most domestic and industrial purposes, and (4) reduction of aesthetic value and recreational use. 


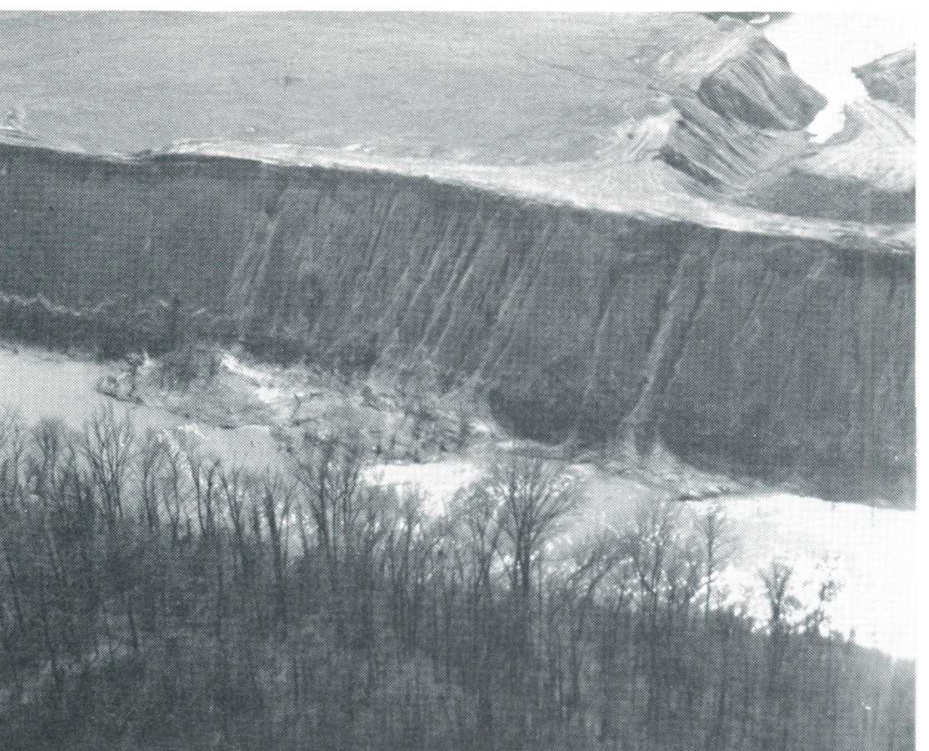

Figure 1.3-1 Spoil banks along Locust Fork of Black Warrior River near Sayre, Jefferson County.
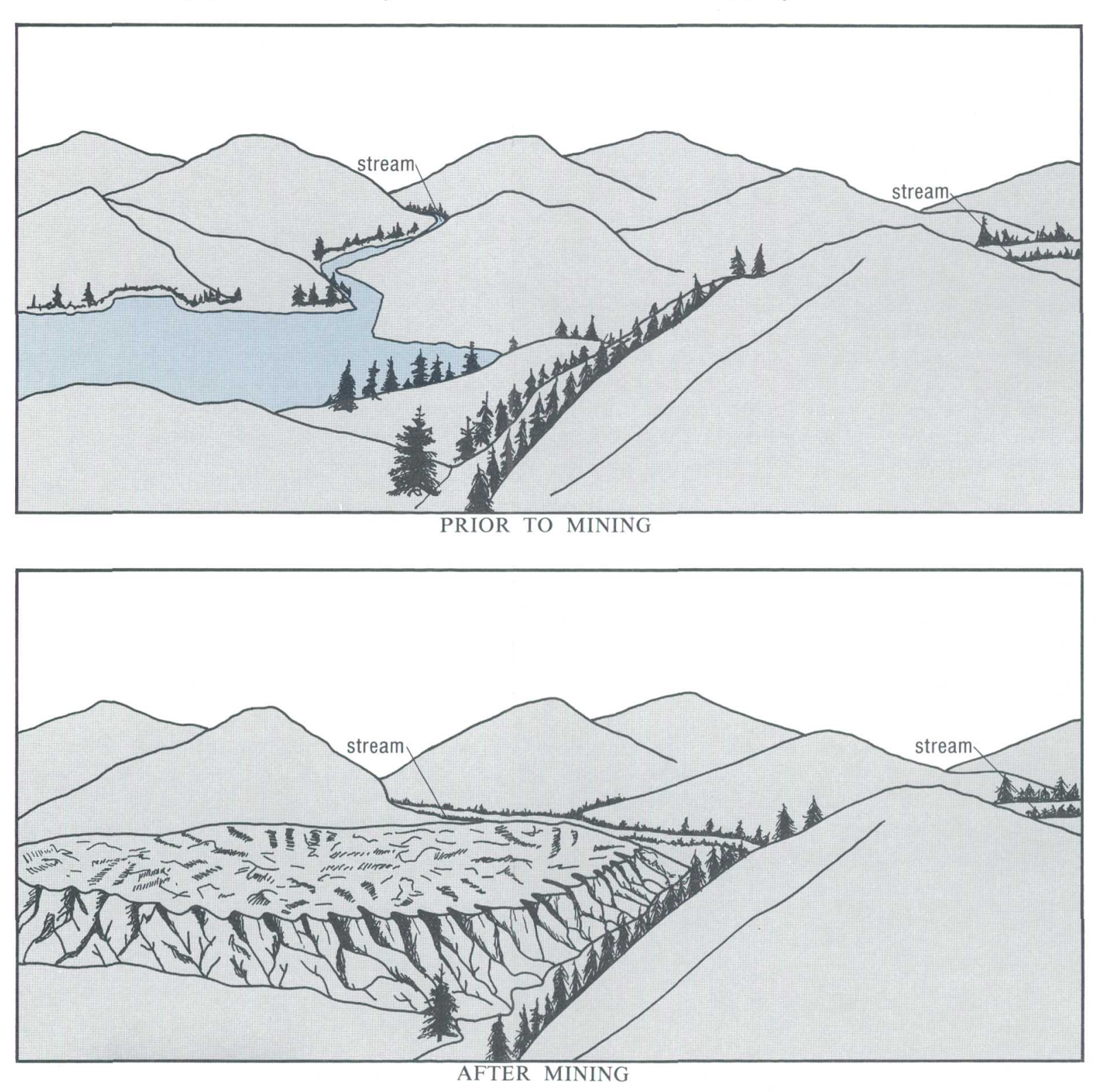

Figure 1.3-4 Possible disruption of drainage patterns resulting from mining operations.
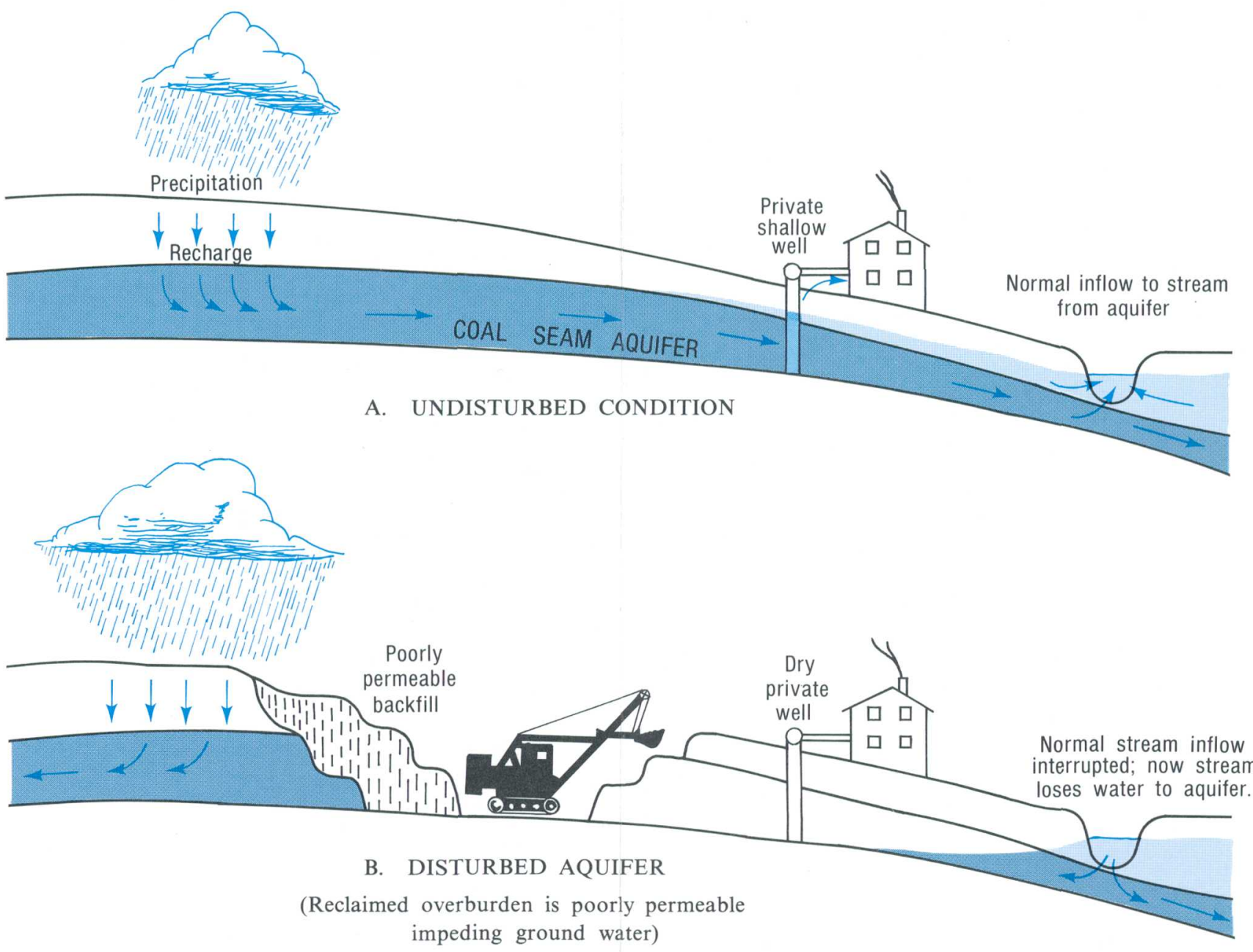

Reclaimed overburden is poorly permeable

impeding ground water)

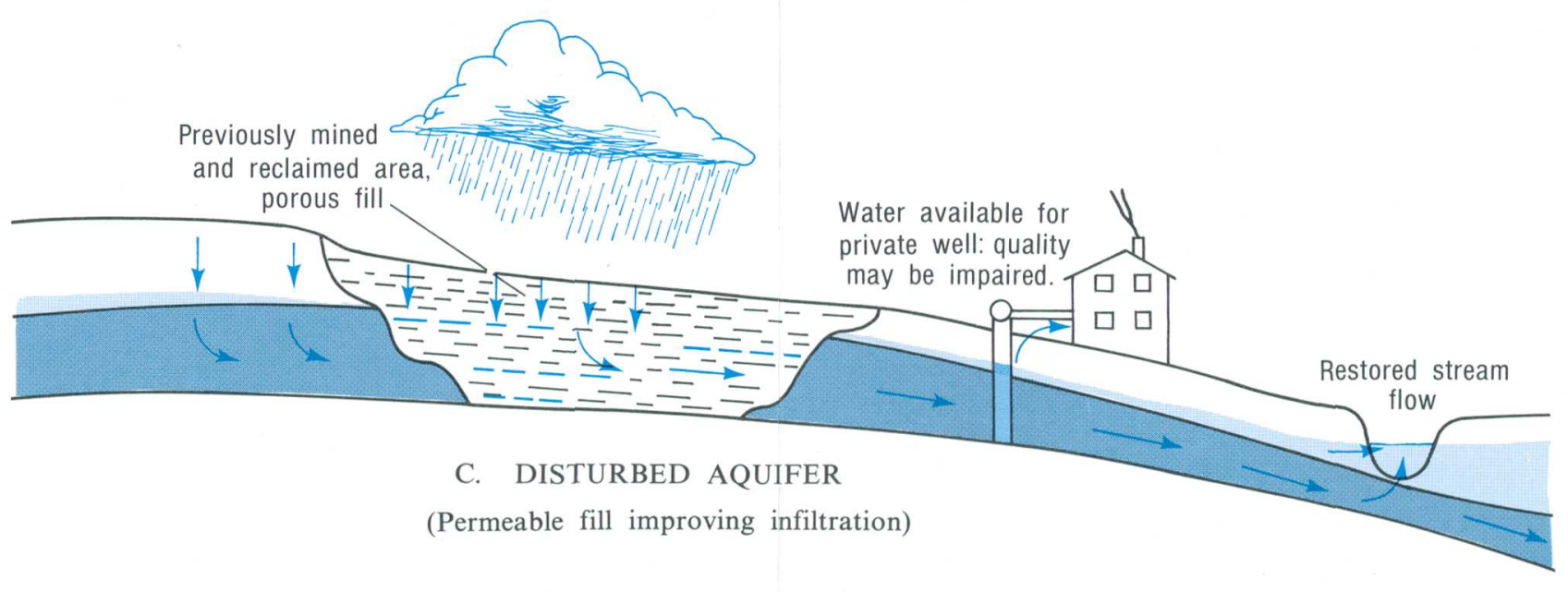

Figure 1.3-3 Possible impacts of mining aquifers 


\title{
2.0 GENERAL FEATURES 2.I GEOLOGY
}

\section{Three Geologic Units Underlie the Area}

\author{
Area 22 is underlain by three principal geologic units: \\ the Pottsville Formation, which contains the coal \\ beds; the undifferentiated pre-Pennsylvanian \\ rocks; and the Tuscaloosa Group.
}

The Pottsville Formation of Pennsylvanian age underlies about 85 percent of Area 22, including all of the central part of the Area. Undifferentiated prePennsylvanian rocks occupy two valleys in the eastern part of the Area and also crop out in the west. The Coker and Gordo Formations of the Tuscaloosa Group of Late Cretaceous age cap the hills in the western part (fig. 2.1.1). The outcrop area of the Pottsville Formation includes parts of two coal fields, the Plateau and the Warrior.

The geologic structure in Area 22 is most complex in the east, where the strata are folded and faulted to form northeast-southwest trending anticlines and synclines. The anticlines have eroded to form the topographic lows of Sequatchie Valley and Murphrees Valley. The synclinal troughs form Sand Mountain and Blount Mountain capped by the erosion-resistant sandstones of the Pottsville Formation. Elsewhere in the Area the strata dip southwestward 30 to $200 \mathrm{ft} / \mathrm{mi}$.

The Pottsville Formation consists chiefly of alternating beds of gray sandstone, conglomerate, siltstone, and shale with beds of coal and underclay. The formation generally becomes thicker to the south because (1) the regional dip to the southwest is greater than the southward slope of the land surface preserving younger beds to the southwest, and (2) the beds of the formation thicken and increase in number to the south and southeast. Thickness of the Pottsville Formation within Area 22 ranges from 210 feet at the northern boundary (Faust and Jefferson, 1980) to 1,400 feet on Blount Mountain in the southeast (Culbertson, 1964). Blount Mountain is located on the downthrown side of a thrust fault which contributes in part to the greater thickness there (see eastern geologic structure section, fig. 2.1-1). In northern Walker County on the southern boundary of the Area, the Pottsville is 1,100 feet thick (McGlamery, 1955). The thickest and most productive coal beds are found in the upper part of the Pottsville above the base of the Black Creek coal bed (Adams, 1926). The outcrop of the Black Creek coal bed generally is considered the boundary between the Plateau Coal Field to the north and the Warrior Coal Field to the south (Mining Information Series, 1978). Lithology is difficult to correlate regionally. Generalized vertical sections showing coal beds are shown in figure 2.1-2.

The undifferentiated pre-Pennsylvanian rocks are about 4,900 feet thick and consist primarily of limestone, dolomite, chert, sandstone, shale, and some beds of hematite. These strata crop out in Sequatchie Valley and Murphrees Valley in the eastern part of the area and in smaller stream valleys in the western part.

The Coker and Gordo Formations of the Tuscaloosa Group unconformably overlie the pre-Pennsylvanian rocks and the Pottsville Formation in the western part of the Area. The Coker is the older of the two.. formations and usually is present below the Gordo. However, in most of the Tuscaloosa Group outcrop in Area 22, the Gordo overlaps the Coker and rests on the Pottsville Formation. The base of the Coker dips toward the southwest about $30 \mathrm{ft} / \mathrm{mi}$; the base of the Gordo dips southwestward about $25 \mathrm{ft} / \mathrm{mi}$ (Causey, 1972). Both formations consist of unconsolidated sand, gravel, and clay with the major gravel beds near the base of each formation. Thickness of the Tuscaloosa Group in Area 22 varies from zero feet at the Pottsville contact to about 50 feet at the western boundary of the area. 


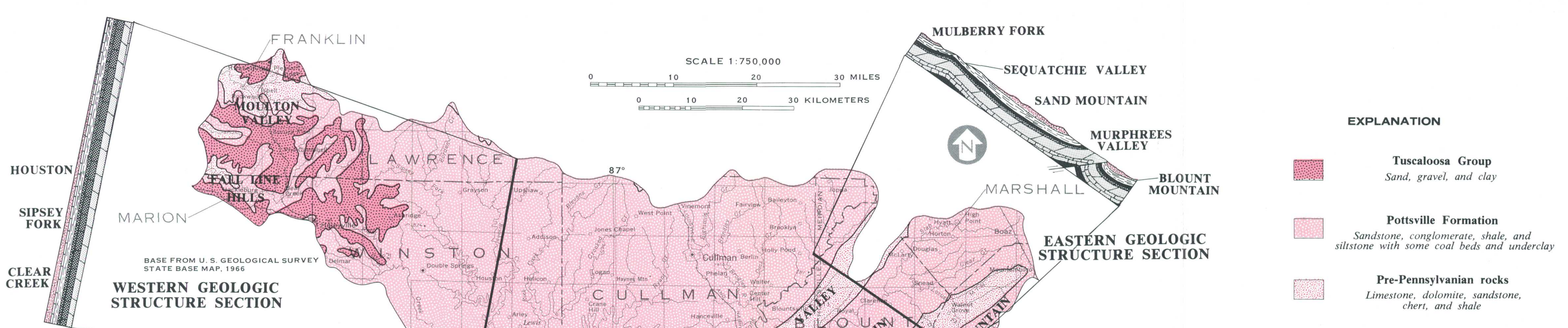

Figure 2.1-1 Geologic map with structure sections.

$$
\text { WALKER }
$$

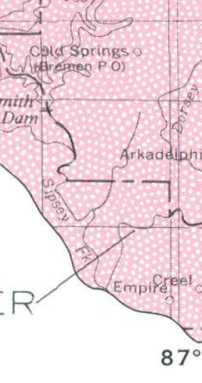

ง. $1{ }^{\circ}$ ETOWAH

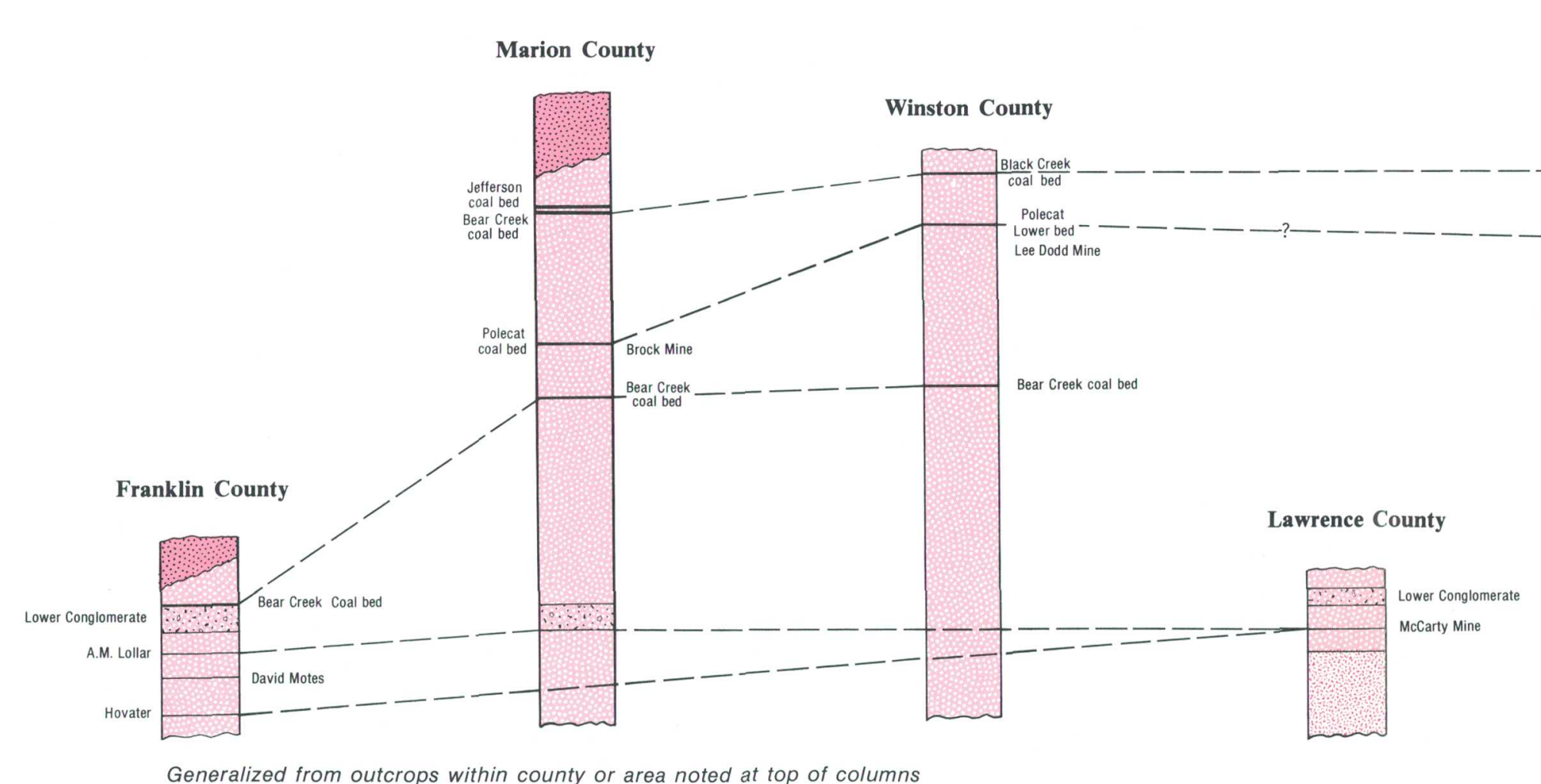

Generalized from outcrops within county or area noted at top of columns

Not to scale but proportional to thickness of average sections

Figure 2.1-2 Generalized columnar sections showing possible relationships of coal beds.

Cullman County Northeastern part of Warrior coal field

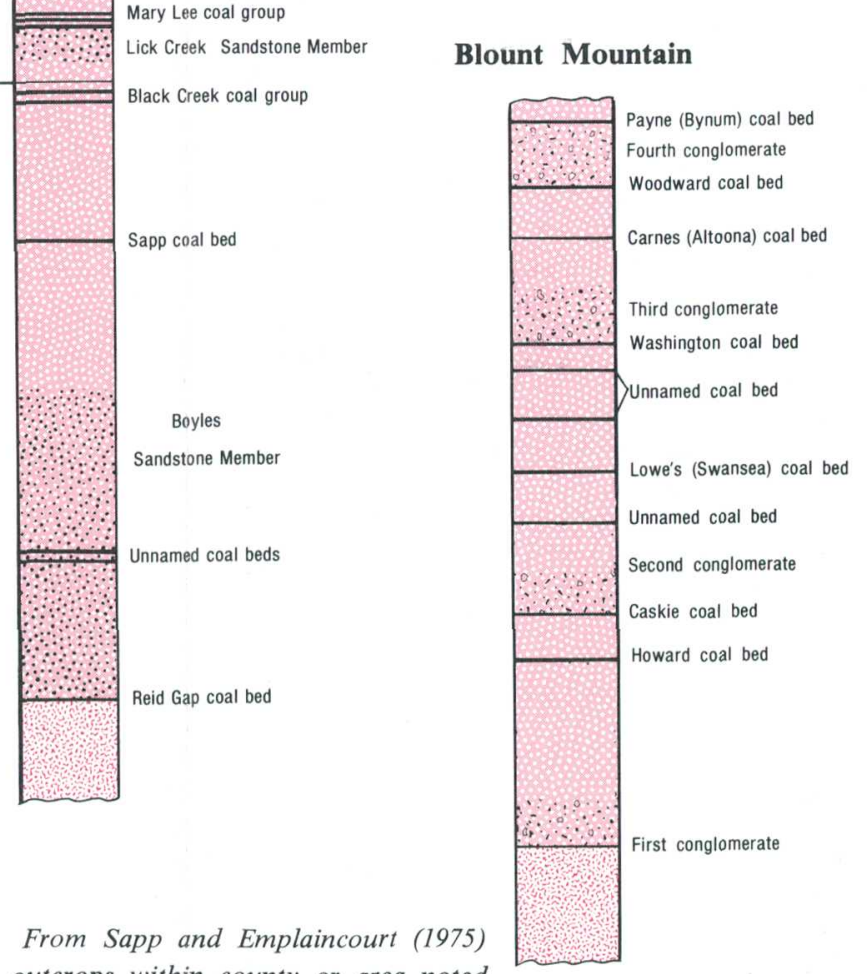




\subsection{GENERAL FEATURES (Continued) 2.2 LAND FORMS}

\section{Area 22 Within Three Physiographic Provinces}

\section{Area 22 lies within three physiographic provinces: Appalachian Plateaus, Interior Low Plateaus, and Coastal Plain.}

Most of Area 22 lies within the Cumberland Plateau section of the Appalachian Plateaus physiographic province. Two other provinces are represented in the area: the Highland Rim section of the Interior Low Plateaus province and the East Gulf Coastal Plain section of the Coastal Plain province (fig. 2.2-1).

The surface of the Cumberland Plateau section is generally higher than that of adjacent provinces. Most of the Plateau is underlain by the Pottsville Formation which contains massive sandstone beds. These beds resist erosion and form escarpments along the edges of the Plateau. In Area 22, a north-facing escarpment delineates the northern boundary of the province (Johnston, 1932). The Plateau surface is dissected by the well-developed drainage patterns of Mulberry Fork of the Black Warrior River and its tributary, Sipsey Fork. Two large northeast-southwest trending valleys lie within the Plateau province in the eastern part of the area. These are Sequatchie Valley and Murphrees Valley, both underlain by pre-Pennsylvanian limestones and dolomites. Each valley is about 3 miles wide and contains two minor stream valleys and an intervening ridge within the major valley. Sand Mountain is a synclinal plateau separating Murphrees Valley from Sequatchie Valley. Blount Mountain is a similar plateau on the east side of Murphrees Valley. Both mountains are extensions of the Plateau upland. Blount Mountain, Murphrees Valley, and Sand Mountain are drained by the Locust Fork of the Black Warrior River.

North of the Cumberland Plateau in Franklin County lies Moulton Valley, a district of the Highland Rim section of the Interior Low Plateaus province. The valley floor is a rolling lowland underlain by prePennsylvanian limestones and drained by streams flowing northwest to the Tennessee River.

Unconsolidated deposits of the Tuscaloosa Group cap the hills and ridges of the western Cumberland Plateau and cover the western part of Moulton Valley. The physiographic region underlain by these deposits is the Fall Line Hills district of the East Gulf Coastal Plain section. The inland margin of the East Gulf Coastal Plain is referred to as the Fall Line, but no topographic expression of the boundary exists in Area 22 (Fenneman, 1938). 


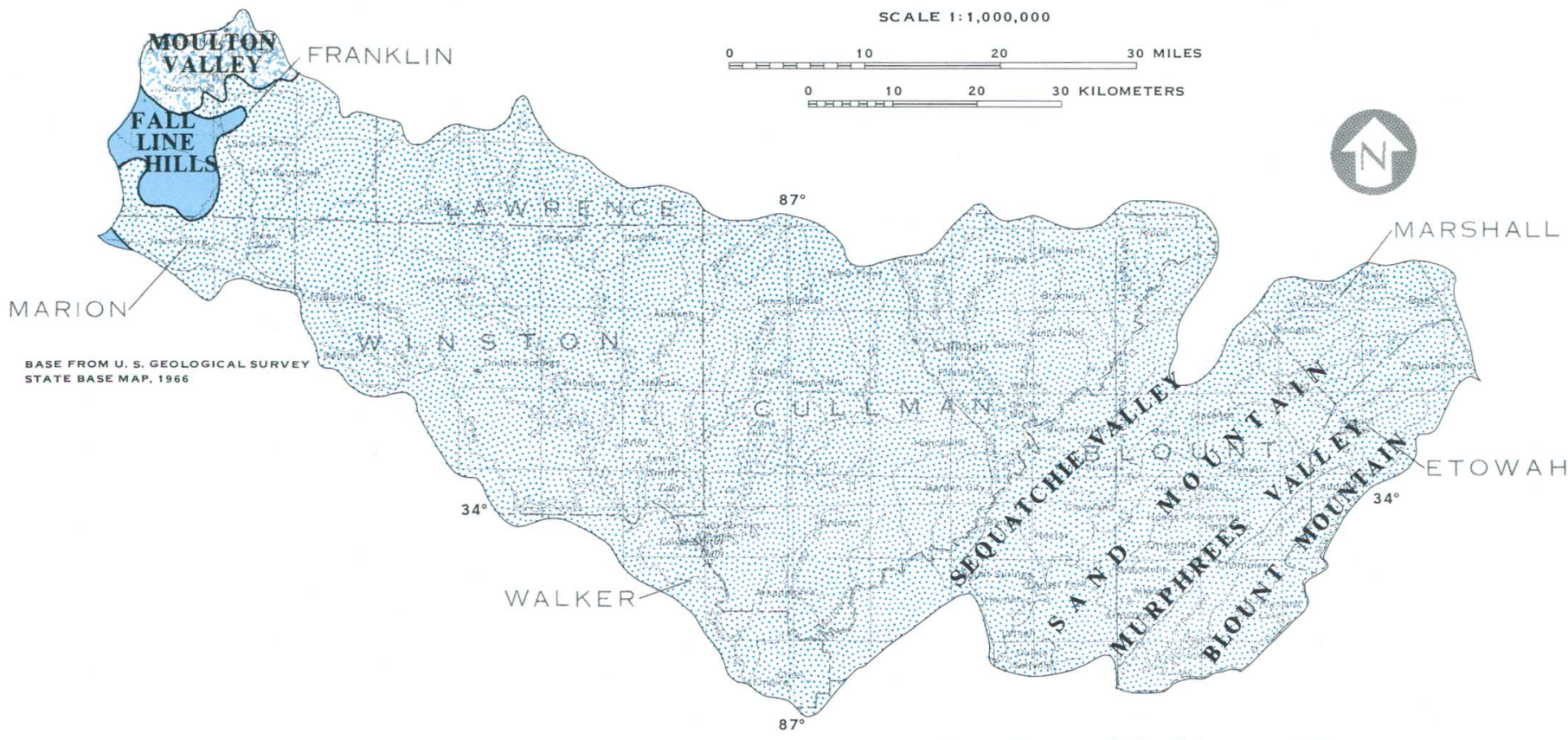

From Sapp and Emplaincourt (1975)

\section{EXPLANATION}

Highland Rim section
(Interior Low Plateaus province)
Cumberland Plateau section
(Appalachian Plateaus province)
East Gulf Coastal Plain section

(Coastal Plain province)

Figure 2.2-1 Physiographic divisions 


\title{
2.0 GENERAL FEATURES (Continued) 2.3 SURFACE DRAINAGE
}

\section{Four Major Streams Drain Area}

\author{
Most of area is drained by Mulberry Fork of the Black Warrior \\ River. Other major streams draining Area 22 are Locust Fork \\ of the Black Warrior River, Sipsey Fork (tributary to \\ Mulberry Fork), and Bear Creek.
}

Mulberry and Locust Forks form the Black Warrior. River downstream in Area 23. The drainage eventually reaches the Mobile River that flows to the Gulf of Mexico. Bear Creek basin is drained by Cedar, Little Bear, and Bear Creeks in Area 22. Bear Creek and its tributaries, Cedar and Little Bear Creeks, drain the western edge of the Plateau Coal Field. Cedar and Little Bear Creeks flow into Bear Creek which flows into the Tennessee River in Pickwick Lake. The flow from the Tennessee River eventually reaches the Mississippi River which also flows into the Gulf of Mexico (fig. 2.3-1).

Locust Fork drains the eastern side of the Plateau Coal Field and part of two valleys of pre-Pennsylvanian rocks. The area drained by Mulberry Fork is underlain almost entirely by coal-bearing rocks of the Plateau Coal Field. The principal tributary to Mulberry Fork is Sipsey Fork. Drainage from $944 \mathrm{mi}^{2}$ of a total drainage area of $999 \mathrm{mi}^{2}$ of Sipsey Fork flows into Lewis Smith Lake. Lewis Smith Dam was closed in 1961 and has a storage capacity of $1,670,700$ acre-feet at spillway crest. Since closure there has been no flow over the spillway. All flow released has been through turbines for hydro-power generation.

Area 22 has a surface area of $2,495 \mathrm{mi}^{2}$ and borders along the Tennessee-Mobile basin divide. Major streams having their headwaters within Area 22 and their drainage areas are as follows:
Basin

Area (square miles)

Mobile River basin

$$
\begin{array}{cr}
\text { Locust Fork } & 624 \\
\text { Mulberry Fork } & 571 \\
\text { Sipsey Fork } & 999 \\
\text { (tributary to } & \\
\text { Mulberry Fork) } & \\
& ---- \\
\text { Total } & 2,194
\end{array}
$$

Tennessee River basin

$\begin{array}{cr}\text { Bear Creek } & 182 \\ \text { Cedar Creek } & 85 \\ \text { Little Bear Creek } & 34\end{array}$

Total 301

Drainage areas for selected locations on streams in Area 22 may be found in Geological Survey of Alabama Atlas Series 12 (1978), "Drainage Areas for the Upper Black Warrior River Basin, Alabama," and U.S. Army Engineers District, Mobile Corps of Engineers report titled, "Stream Mileage Tables with Drainage Areas" (1972). Drainage areas in the Bear Creek basin may be obtained from the Tennessee Valley Authority, Data Services Branch, Room 329 Evans Building, 524 Union Ave., Knoxville, TN 37902. 


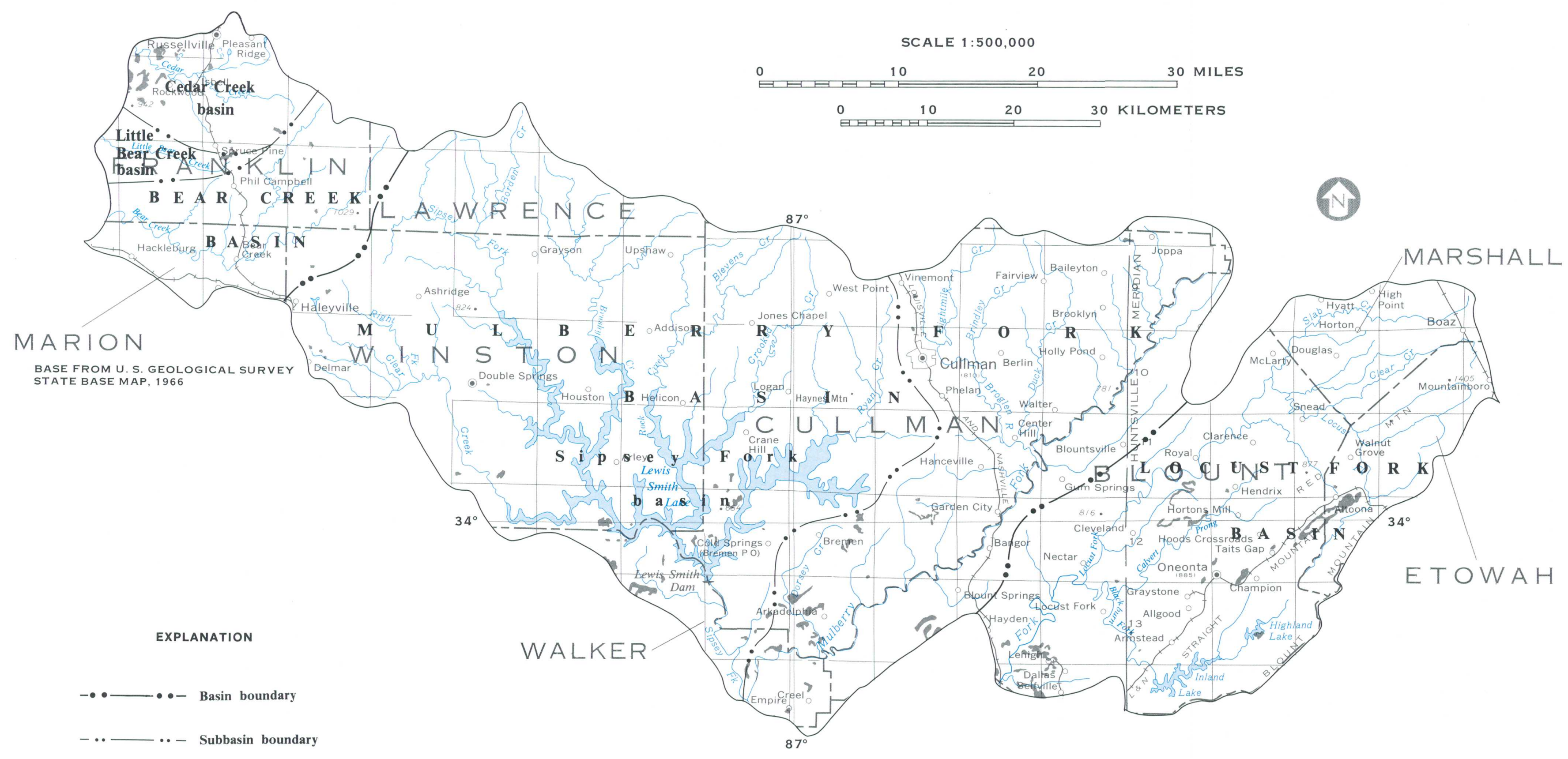

Strip Mines, Quarries, 


\title{
2.0 GENERAL FEATURES (Continued) \\ 2.4 LAND USE
}

\section{Forest and Agricultural Land Cover Most of Area 22}

\author{
Forest land covers majority of Area 22, followed closely by \\ agricultural land. Remaining land use is approximately \\ evenly divided between urban land, \\ barren land, and water.
}

Area 22 was grouped into six land use and land cover categories and these categories are shown on the land-use and land-cover map (fig. 2.4-1).

The regimen of flow is affected by the use of the land surface. Where coal is surface mined the slope and shape of the land surface is changed; great depths of overburden are broken, mixed, and rearranged; and the rate of infiltration is increased or decreased according to the materials at the surface. Generally, the infiltration rate is increased immediately after mining but as water decomposes the material through which it percolates the rate changes. Urban and industrial development of large areas may reduce infiltration rate due to paving, roof tops, and storm sewers. Changes in cultivated land from row crops to pasture or timber also have an effect on infiltration and runoff rates.

Inasmuch as the land surface is the source of sediment, there can be a drastic change in sediment yield when the land surface is changed from forest to bare surface-mined land.

Land-use and land-cover information and maps in greater detail may be found in U.S. Geological Survey open-file reports titled Land Use Series. Information on the Land Use Series is available from the National Cartographic Information Center, U.S. Geological Survey, National Center, Reston, Virginia 22092. 


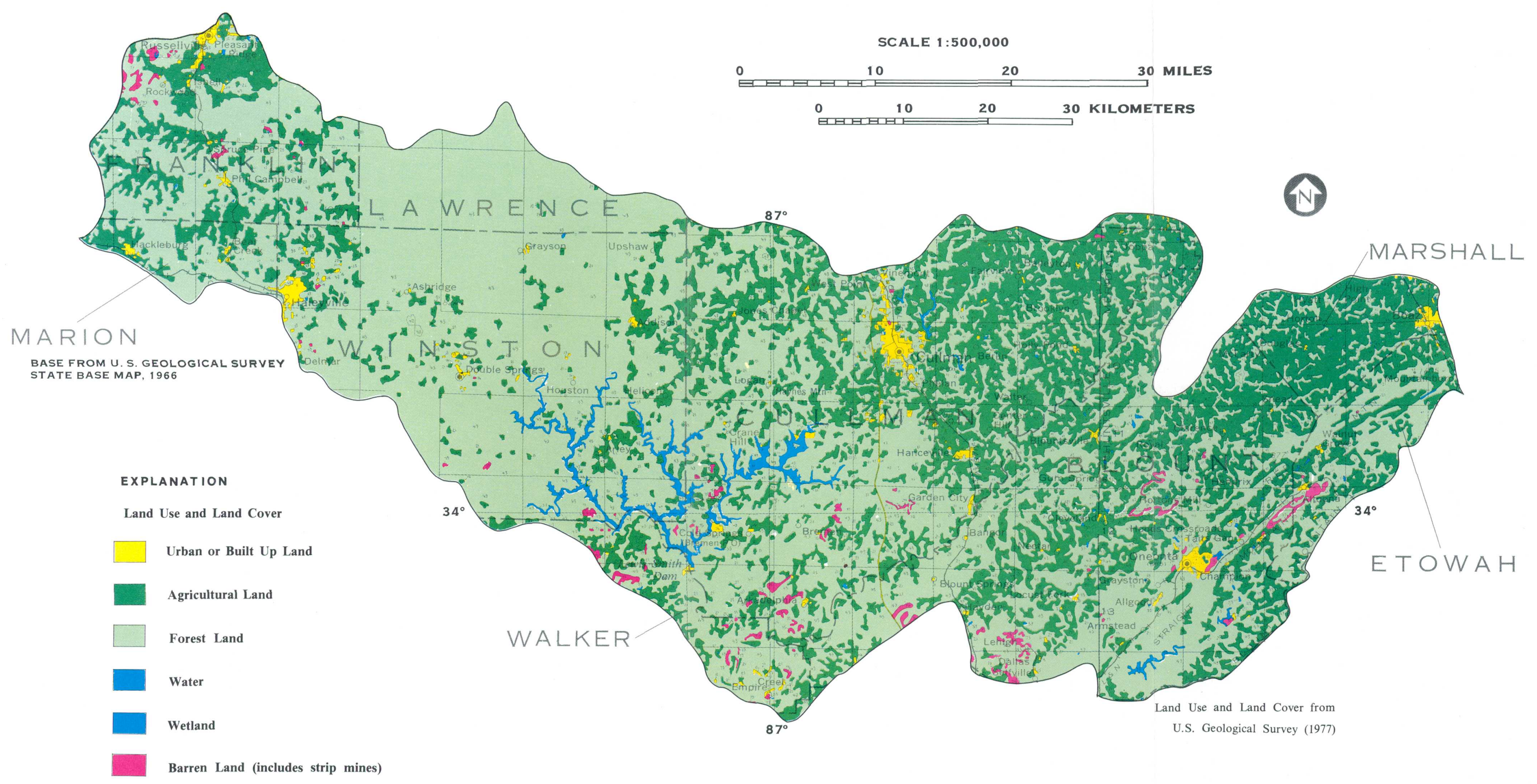

Figure 2.4-1 Land use and land cover 


\title{
Soils Are Acidic and Generally Have High Erosion Potential
}

\begin{abstract}
Soils in the area are acidic, with $\mathrm{pH}$ ranging from 3.6 to 6.0 units, and are easily eroded when vegetative cover is removed.
\end{abstract}

Soils in Area 22 generally have high acidity, high erosion potential, low organic content, low natural fertility, and moderate permeability rates (Buckman, 1969). Factors affecting erosion potential include: infiltration and permeability rates, soil texture and stability, soil depth, slope gradient, and vegetative cover. Removal of vegetative cover drastically alters natural erosion patterns. Erosion increases as the slope increases.

The generalized soil map for Area 22 shows three predominant soil associations (fig. 2.5-1). These associations are characterized by the U.S. Soil Conservation Service's Established Soil Series Descriptions and are summarized in table 2.5-1.
Factors affecting soil suitability for plant growth media on disturbed lands are listed in table 2.5-2. The Minvale-Fullerton and Savannah-Ruston-Stough associations are fairly suitable for use as plant growth media in drastically disturbed land reclamation. The MontevalloEnders-Townley association is fairly poor for plant growth purposes due to its acidity and low available water capacity.

The soils map and soil association descriptions are very generalized. Detailed information for individual counties is available from the U.S. Soil Conservation Service. 
Table 2.5-1 Soil association features

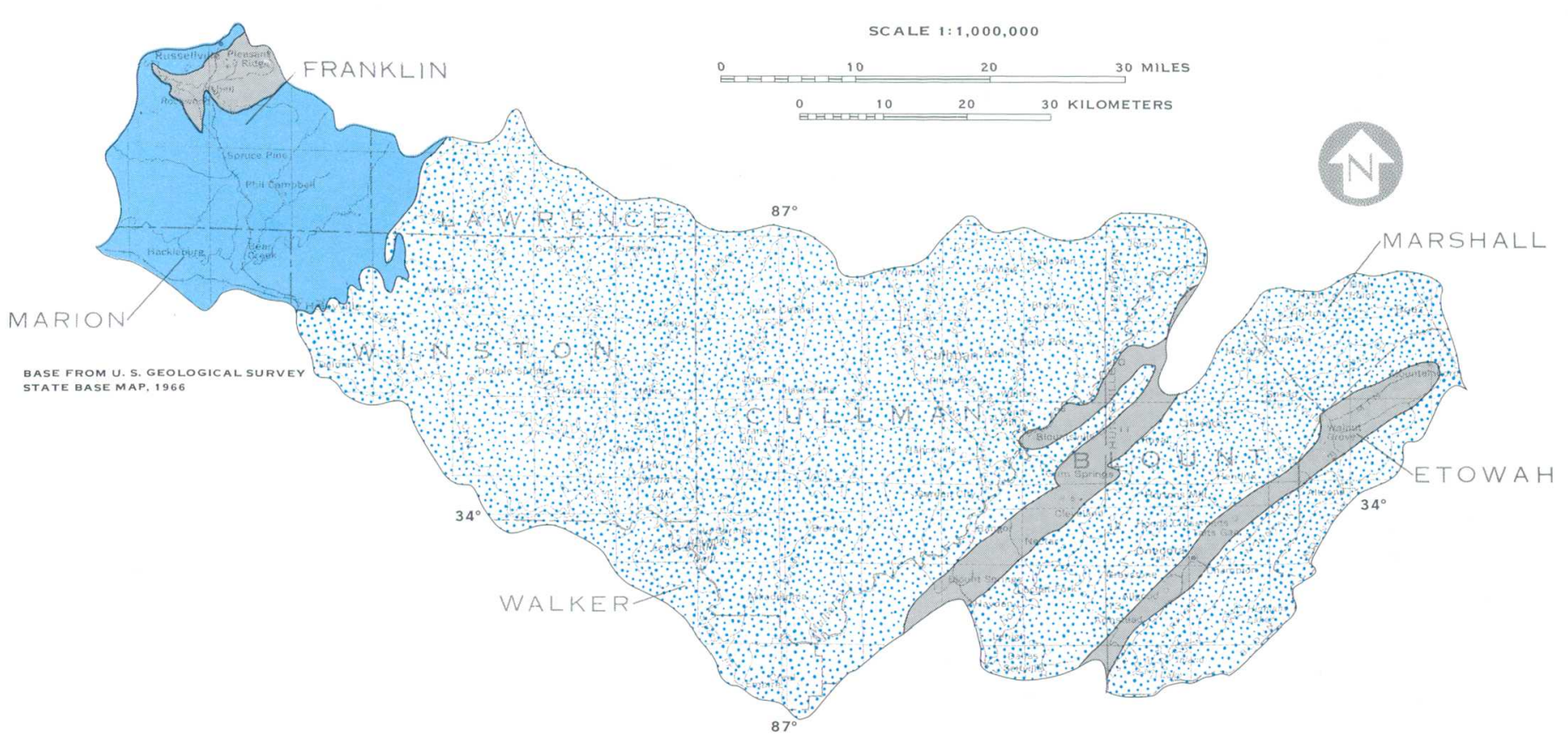

Soils modified from U.S. Department of Agriculture (1974)

EXPLANATION

SOIL ASSOCIATIONS

Minvale-Fullerton

Deep soils over limestone

Montevallo-Enders-Townley

Shallow to moderately deep well drained

soils over shale and sandstone

Savannah-Ruston-Stough

Deep, moderately poor to well drained

soils that have a fragipan

\begin{tabular}{cccccccc}
\hline Soil Association & Physical description & $\begin{array}{c}\text { Solil depth } \\
\text { (inches) }\end{array}$ & $\begin{array}{c}\text { Depth to } \\
\text { bedrock (feet) }\end{array}$ & pH units & $\begin{array}{c}\text { Permeability } \\
\text { (inches/hour) }\end{array}$ & $\begin{array}{c}\text { Avaliable water } \\
\text { capacity } \\
\text { (inches/inch) }\end{array}$ & $\begin{array}{c}\text { Slope } \\
\text { (percent) }\end{array}$ \\
\hline Minvale-Fullerton & $\begin{array}{l}\text { Cherty sitt loam underlain } \\
\text { by limestone }\end{array}$ & $>80$ & 76 & $4.5-5.5$ & $0.6-2.0$ & $0.09-0.16$ & $2-45$ \\
$\begin{array}{l}\text { Montevallo-Enders- } \\
\text { Townley }\end{array}$ & $\begin{array}{l}\text { Shaly sitt loam underlain } \\
\text { by shale and sandstone }\end{array}$ & $10-59$ & $1-6$ & $3.6-6.0$ & $0.06-2.0$ & $0.02-0.18$ & $2-45$ \\
$\begin{array}{l}\text { Savannah-Ruston- } \\
\text { Stough }\end{array}$ & $\begin{array}{l}\text { Loamy soils and subsoils } \\
\text { with a fragipan* }\end{array}$ & $>60$ & $>5$ & $4.0-5.5$ & $0.2-6.0$ & $0.05-0.12$ & $0 .-8$ \\
\hline
\end{tabular}

"Fragipan - Dense and brittle pan or layer in soils that owes its hardness mainly to extreme density or compactness rather than high clay content or cementation - water moves through it very slowly (Buckman, 1969, 610 p.)

Table 2.5-2 Suitability rating of soil (to a depth of 3.28 feet) for use as a plant growth medium in drastically distributed land reclamation.

\begin{tabular}{|c|c|c|c|}
\hline \multirow[t]{2}{*}{ Factors affecting use } & \multicolumn{3}{|c|}{ Degree of suitability } \\
\hline & Good & Fair & $\begin{array}{c}\text { Poor } \\
\text { (essentially } \\
\text { unsuitable) }\end{array}$ \\
\hline Electrical conductivity $\mathrm{ECC} \begin{array}{l}\text { (merromonos per } \\
\text { centimeter at } 25 \mathrm{C}^{\circ} \text { ) }\end{array}$ & $<8$ & $8-16$ & $>16$ \\
\hline Sodium absorption ratio SAR & $<2$ & 2-12 & $>12$ \\
\hline Exchangeable-sodium-percentage ESP* & $<2$ & 2-15 & $>15$ \\
\hline pH units & $5.0-8.5$ & $3.5-5.0$ & $<3.5 ;>8.5$ \\
\hline $\begin{array}{l}\text { Coarse fragments over } 3 \text {-inches diameter } \\
\text { (percent by volume) }\end{array}$ & $<15$ & $15-35$ & $>35$ \\
\hline Intermediate textural group & $\begin{array}{c}\text { medium } \\
\text { moderately fine } \\
\text { moderately coarse }\end{array}$ & fine & coarse \\
\hline Available water capacity (inches/inch) & $>0.1$ & $0.1-0.05$ & $<0.05$ \\
\hline Depth to bedrock or cemented pan & $>40$ inches & 20-40 inches & $<20$ inches \\
\hline Slope (percent) & $<8$ & $8-15$ & $>15$ \\
\hline
\end{tabular}

"Rate 2:1 Clay texture poor if over 10; sand texture if over 20.

Source: U.S. Department of the Interior, 1977 


\subsection{GENERAL FEATURES (Continued) 2.6 PRECIPITATION}

\section{Area 22 Characterized By Moist Temperate Climate}

\section{Area 22 has a moist temperate climate with the heaviest rainfall occurring in March and the least rainfall occurring in October.}

The location of Area 22 gives it a moist temperate climate, with a mean annual rainfall that ranges from 52 inches along the western edge to 56 inches in the southern part of the area. Rainfall is fairly well distributed throughout the year. Winter is the wettest season and March the wettest month. Thunderstorms occur throughout the year, but are most frequent during the spring and summer months; most of the rainfall in these months occurs during these storms. July has the most rainfall of the spring and summer months. The driest months are in the fall with October being the driest month. Rainless periods lasting more than 2 or 3 weeks are rare.

Mean annual precipitation, in inches, for Alabama is shown in figure 2.6-1 for the period 1931-55. Distribution of rainfall by months for St. Bernard, NOAA Weather station, located at Cullman is shown in figure 2.6-2. Normal precipitation is for the 30-year base period of 1941-70. The extremes for the base period are not readily available; however, the extremes for 1907-56 are available and these values are used to show variations above and below normal.

Daily observations of precipitation data may be used to develop various relationships and correlations and for other statistical analyses. For example, the results of an analysis using 24-hour rainfall to compute the 10-year 24-hour rainfall intensities are shown in figure 2.6-3.

Daily precipitation data are published monthly as "Climatological Data for Alabama" by the National Oceanic and Atmospheric Administration, National Climatic Center, Ashville, N. C. Statistical information on analyses and data are presented in U.S. Department of Commerce, Weather Bureau, Technical Paper No. 40 titled, "Rainfall Frequency Atlas of the United States." 

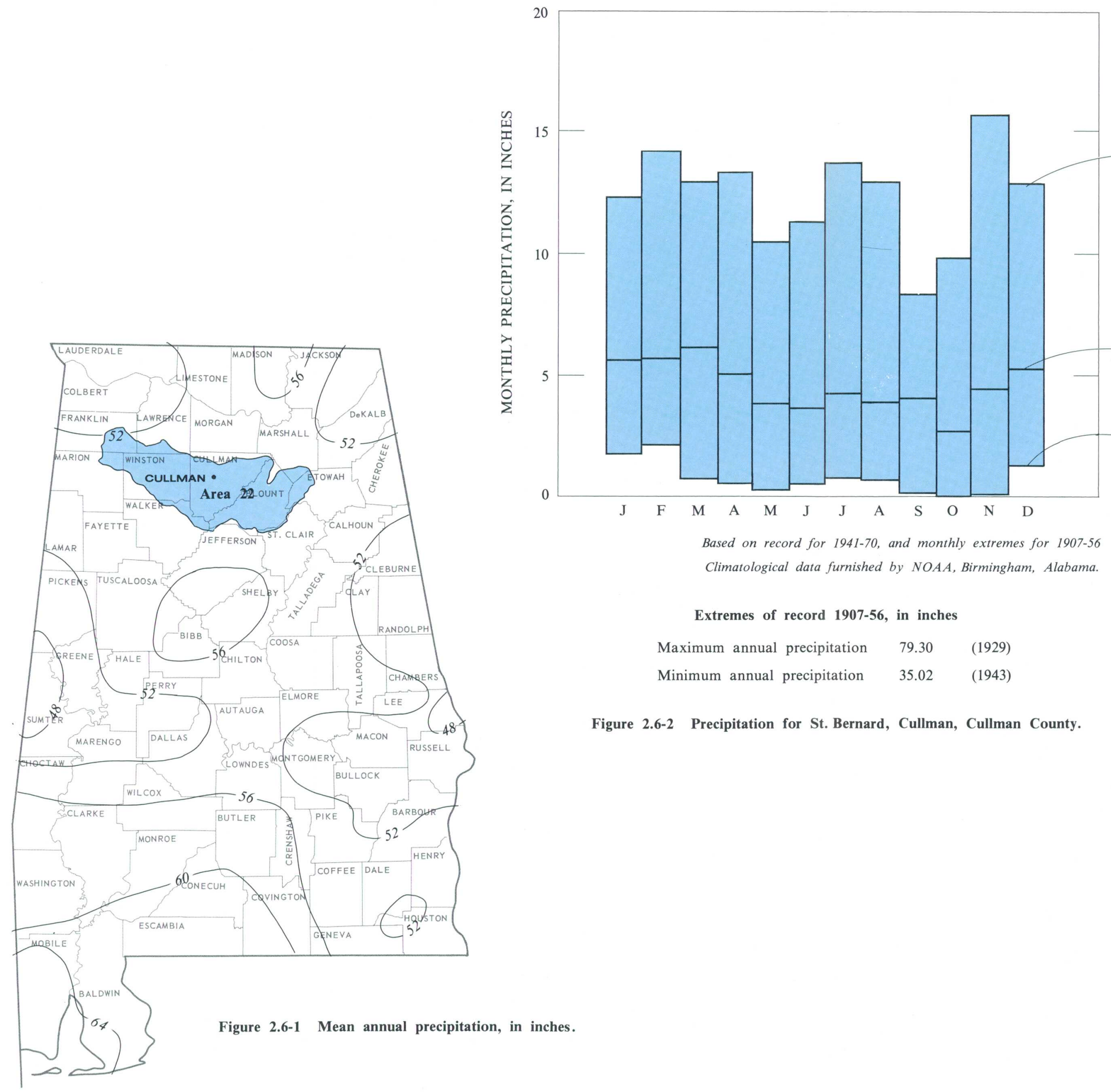

Maximum (1907-56)

Normal (1941-70)

Annual normal 55.15 inches (1941-70)

Minimum $(1907-56)$

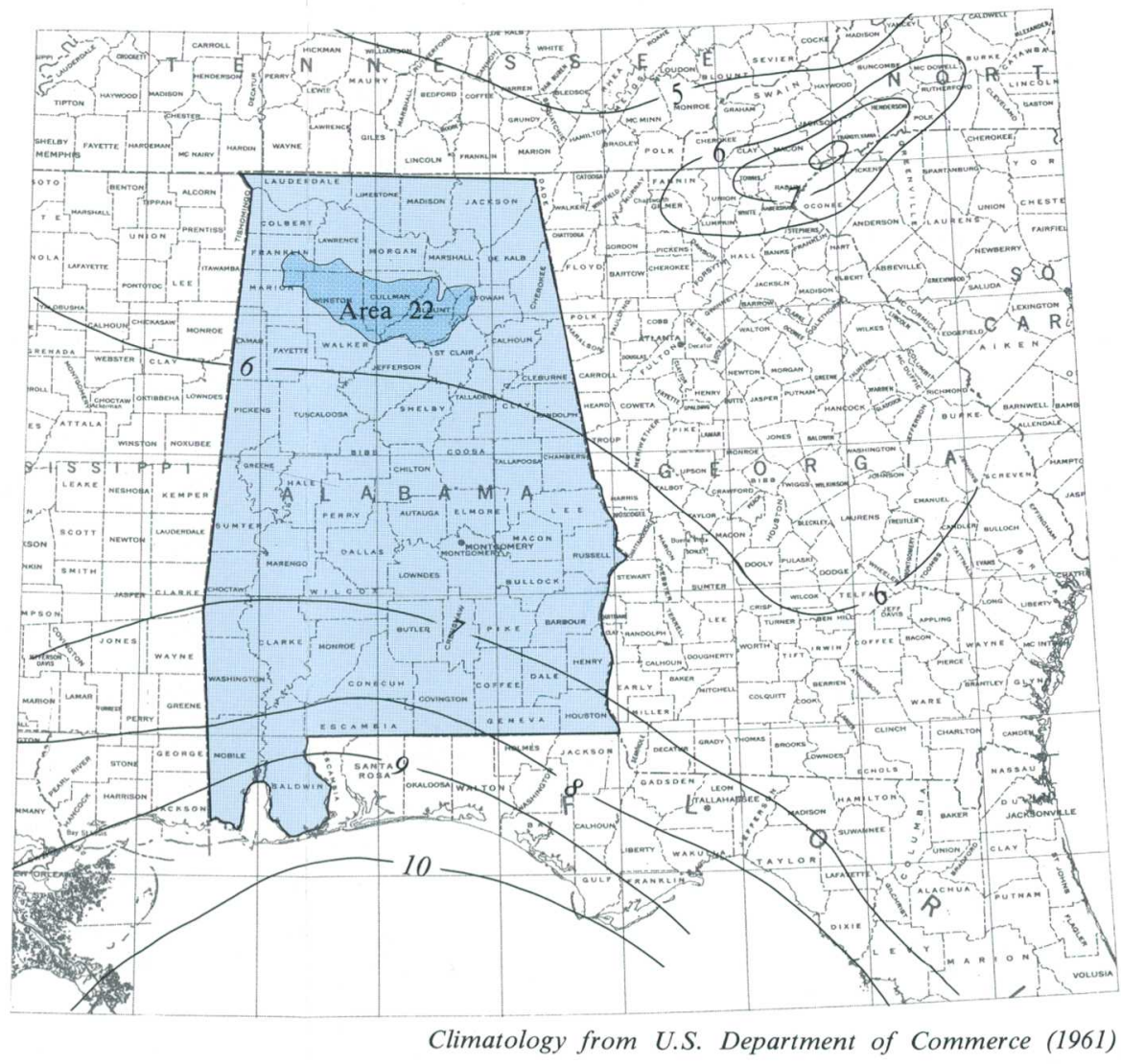

Figure 2.6-3 10-year 24-hour rainfall intensities, in inches.

2.0 GENERAL FEATURES (Continued) 2.6 PRECIPITATION 


\title{
3.0 WATER USE
}

3.I WATER USE IN 1975

\section{Principal Water Uses in Area 22 are for Hydroelectric Power Generation, Public, and Industrial Supplies}

\begin{abstract}
About $900 \mathrm{Mgal} / \mathrm{d}$ in 1975 was from Lewis Smith Lake for hydroelectric power generation. Public and industrial water supplies account for approximately $35 \mathrm{Mgal} / \mathrm{d}$--about 85 percent was water from streams and lakes and 15 percent was ground water from wells and springs.
\end{abstract}

\begin{abstract}
Water use for 1975, for hydroelectric power generation, was approximately $900 \mathrm{Mgal} / \mathrm{d}$ (95 percent) of the total water use in Area 22. Major sources of surfacewater supply are Sipsey Fork immediately downstream from Lewis Smith Lake, Calvert Prong, Inland Lake on Blackburn Fork, Brindley Creek, Eightmile Creek, Pope Creek, and Clear Creek. Sipsey Fork and Inland Lake also serve as major water supplies for municipalities in Area 23 (fig. 3.1-1). Surface-water withdrawals accounted for 74 percent $(32.3 \mathrm{Mgal} / \mathrm{d})$ of the total water withdrawn from the area in 1975 .

Water withdrawal by rural residents was less than 1 percent. Rural use was for domestic purposes (3.5 $\mathrm{Mgal} / \mathrm{d})$, livestock watering (3.2 Mgal/d), irrigation (0.6 $\mathrm{Mgal} / \mathrm{d})$, and catfish farming $(0.7 \mathrm{Mgal} / \mathrm{d})$. Approximately 74 percent of the rural water supply is from ground-water sources.
\end{abstract}

Nonconsumptive water use was more than 95 percent of the total water use in Area 22 for 1975. Hydroelectric power generation at the Lewis Smith Dam by Alabama Power Company was $900 \mathrm{Mgal} / \mathrm{d}$. Water use for hydroelectric power generation, public and industrial supply, and rural supply are shown in figure 3.1-2.

The preceding data were taken from the report entitled, "Use of Water in Alabama, 1975, With Projections to 2020" (Mettee, 1978). Additional information on water use is contained in "Estimated Use of Water in the United States in 1975" (Murray, 1977).

Water-use data for 1980 are being collected and compiled by states and will be available through the National Water Data Exchange (NAWDEX). For details about NAWDEX see section 9 of this report. 


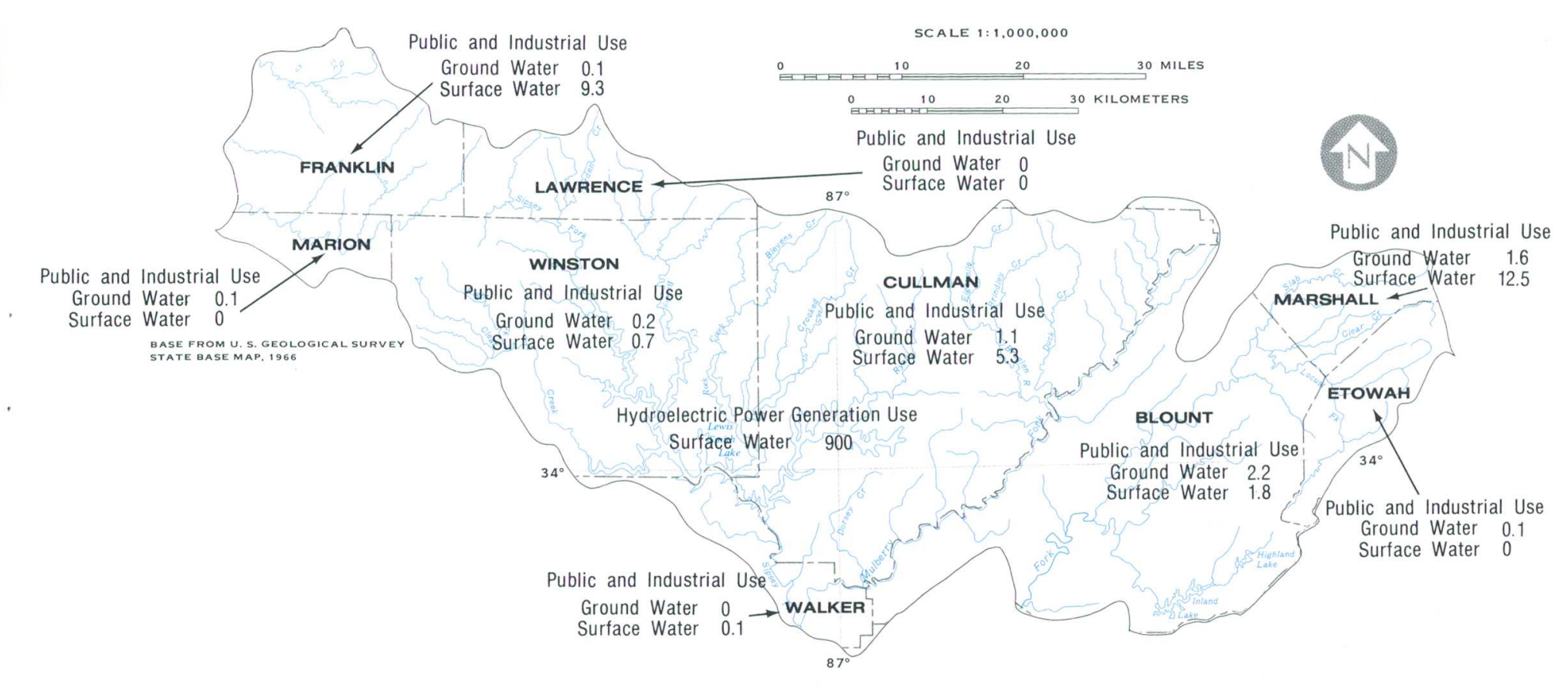

Water use values by county prorated for Area 22.

Figure 3.1-1 Water use by county, in million gallons per day.
Total water use - 943.1 million gallons per day

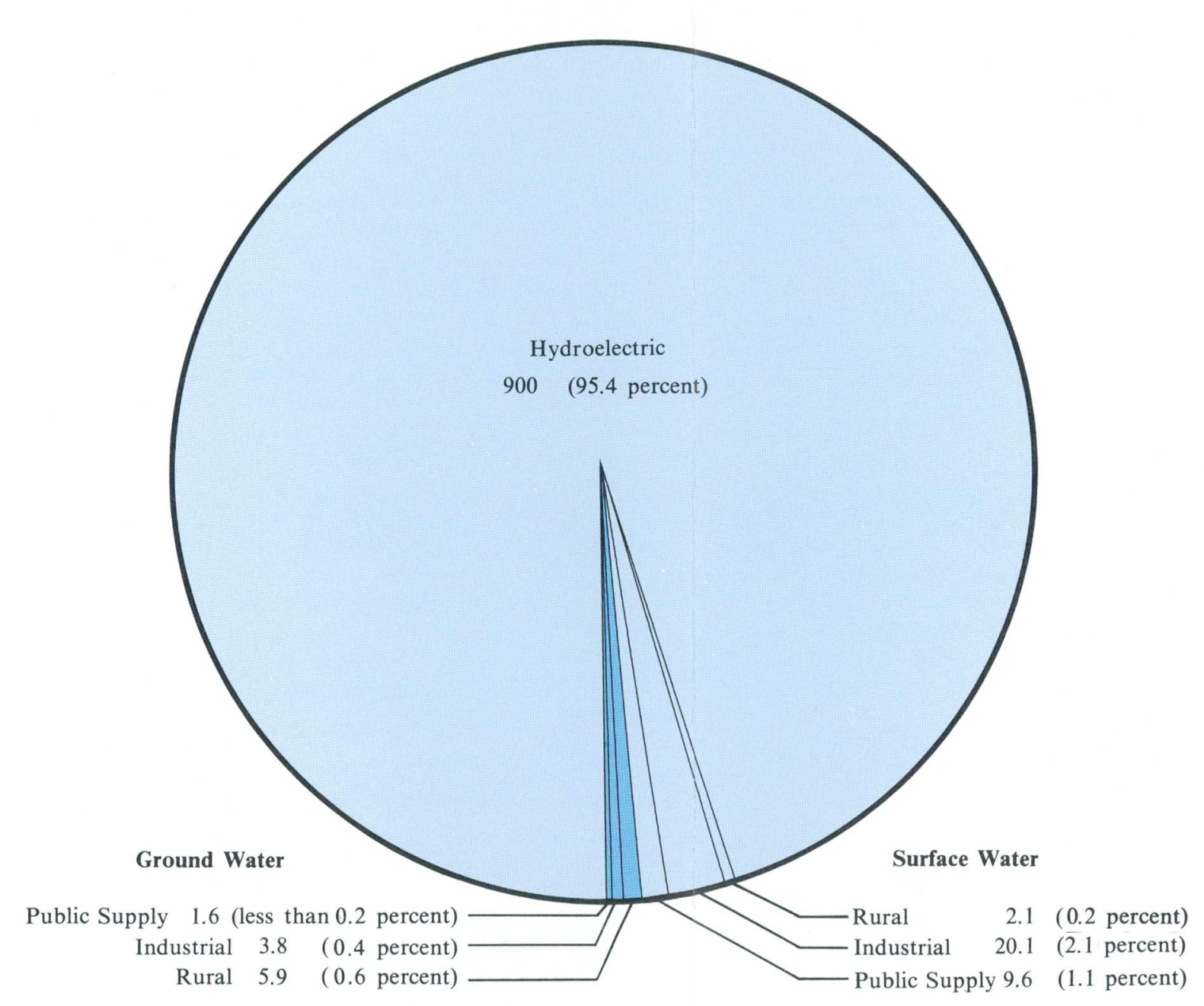

Figure 3.1-2 Water use, in million gallons per day. 


\subsection{WATER USE (Continued) \\ 3.2 USE CLASSIFICATION OF STREAMS}

\section{Most Streams in Area 22 Have Fish And Wildlife or Better-Use Classification}

\section{The Alabama Water Improvement Commission has classified most streams in Area 22 as Fish and Wildlife or better use.}

Use classification of stream reaches is shown in figure 3.2-1. The reaches as classified in March 1979 for Area 22 by the Alabama Water Improvement Commission, also given in Appendix 1, show most streams are classified as "Fish and Wildlife" or better (E. John Williford, written comm.).

All major streams and stream segments that to the Commission's knowledge are currently recipients of point-source discharges are included in the classification. In every instance where a segment is not included by name, the Commission has no information to assign a particular classification. However, the assumption was made by the Commission that these unnamed segments are classified as "Fish and Wildlife" and will remain so unless it is demonstrated that they are improperly classified.

Although not explicitly stated in the classifications, that with the exception of those segments in the "Public Water Supply" classification, every stream segment in addition to being considered acceptable for its designated use is also considered acceptable for any other use with a less stringent associated criteria. 


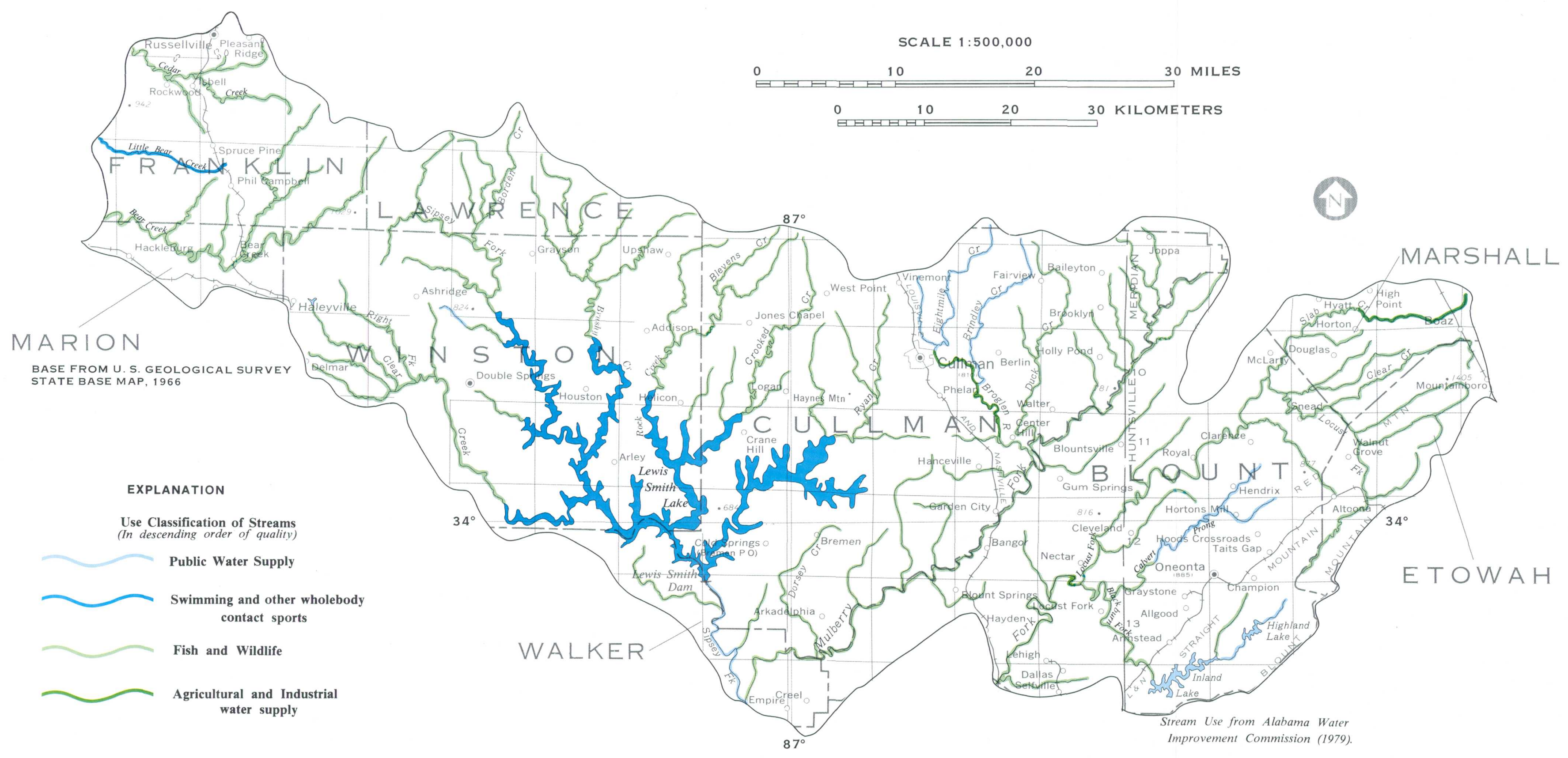

Figure 3.2-1 Use classification of Streams. 


\title{
4.0 HYDROLOGIC NETWORKS \\ 4.I SURFACE WATER
}

\section{Information on Surface Water is Available for 74 Locations}

\author{
The U.S. Geological Survey surface-water data-collection network \\ for Area 22 was extended in response to the Surface Mining \\ Control and Reclamation Act of 1977 (Public Law 95-87), \\ and information on surface water is now available for \\ 74 locations.
}

Streamflow and water-quality information is available for 74 sites in Area 22; these surface-water sites are shown on figure 4.1-1, and details for the period of record and type of data available are given in Appendix 2. Before the passage of Public Law 95-87 the network consisted of six active stations. The active network has been increased to 25 sites by the Survey to obtain data needed to assess the hydrology of the general area and as an aid to mine owners and operators, consulting engineers, and the Regulatory Authority in evaluating the hydrologic consequences of mining.
Water-quality data are obtained at all of the surfacewater stations. Several types of data may be collected at a particular site, but all types of data are not necessarily collected at each site. Details about period of operation and type of data as well as the actual data are available from computer storage through National Water Data Exchange (NAWDEX) and in published annual U.S. Geological Survey reports, "Water Resources Data for Alabama." 


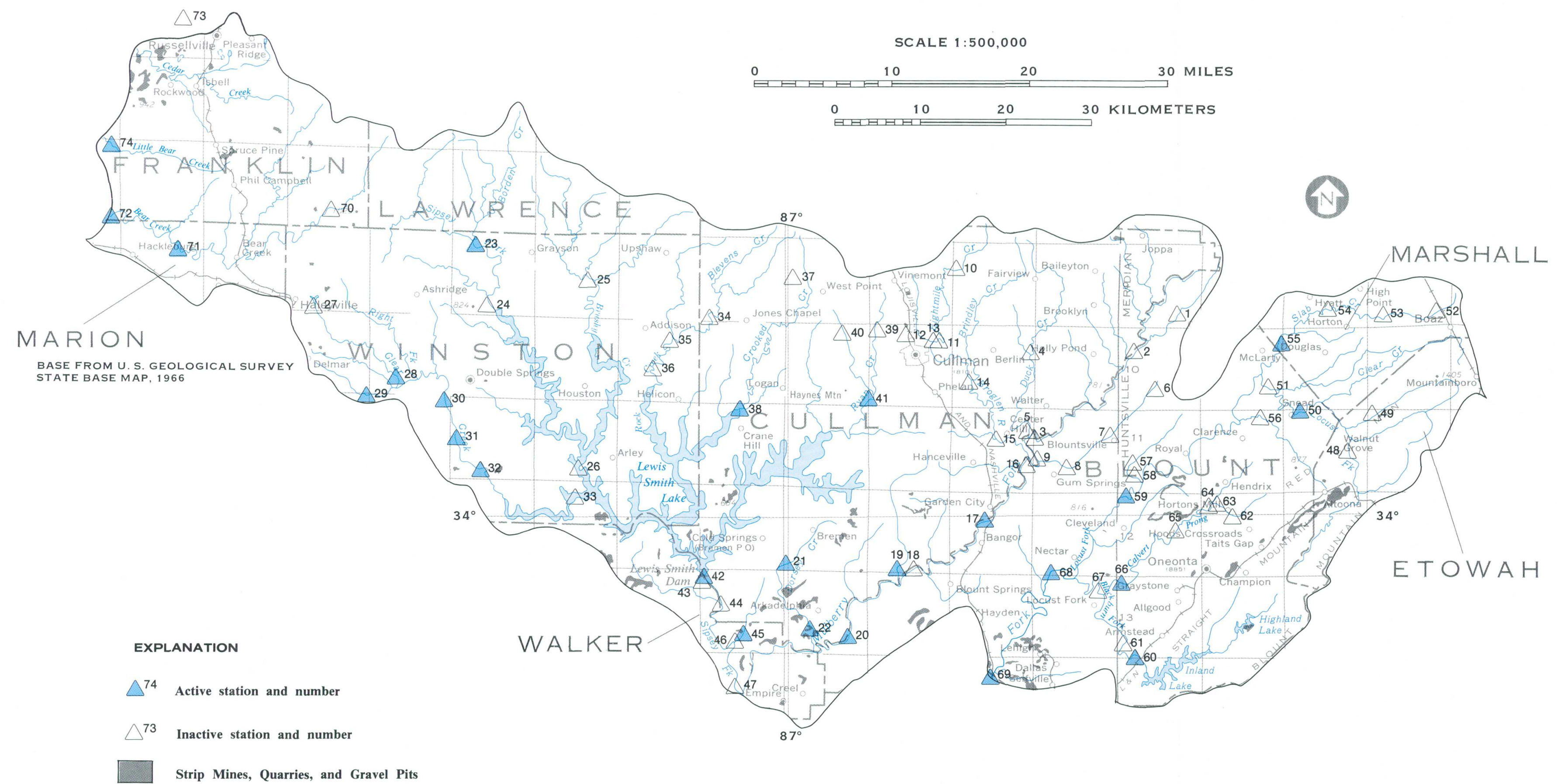

See Appendix 2 for detailed station description.

Figure 4.1-1 Surface-water network 


\subsection{HYDROLOGIC NETWORKS (Continued) \\ 4.2 GROUND WATER}

\section{Information on Ground-Water Levels and Spring Discharge is Available for 17 Locations}

\section{The U.S. Geological Survey ground-water network includes 13 monitoring wells and 4 springs in Area 22.}

The ground-water network in Area 22 provides water-level and spring-discharge data, which combined with water-quality data, will aid applicants for coalmining permits, mine owners and operators, consulting engineers, and regulatory agencies in determining the impact of coal mining on the ground-water resources of the permit area.

Water-level data for 13 wells and discharge data for 4 springs are available, including continuous records for 3 wells and 2 springs. The remaining wells and springs have been measured periodically. Locations of the network stations are shown on figure 4.2-1. Information including identification numbers, county, aquifer, and period of record for each station is given in Appendix 3. Additional information about the type of data, including the actual data, is available from (1) the National Water Data Exchange (NAWDEX), (2) the National Water Data Storage and Retrieval System (WATSTORE), (3) published annual U.S. Geological Survey reports, "Water Resorces Data for Alabama", and (4) reports on water availability for individual counties published by the Geological Survey of Alabama. 


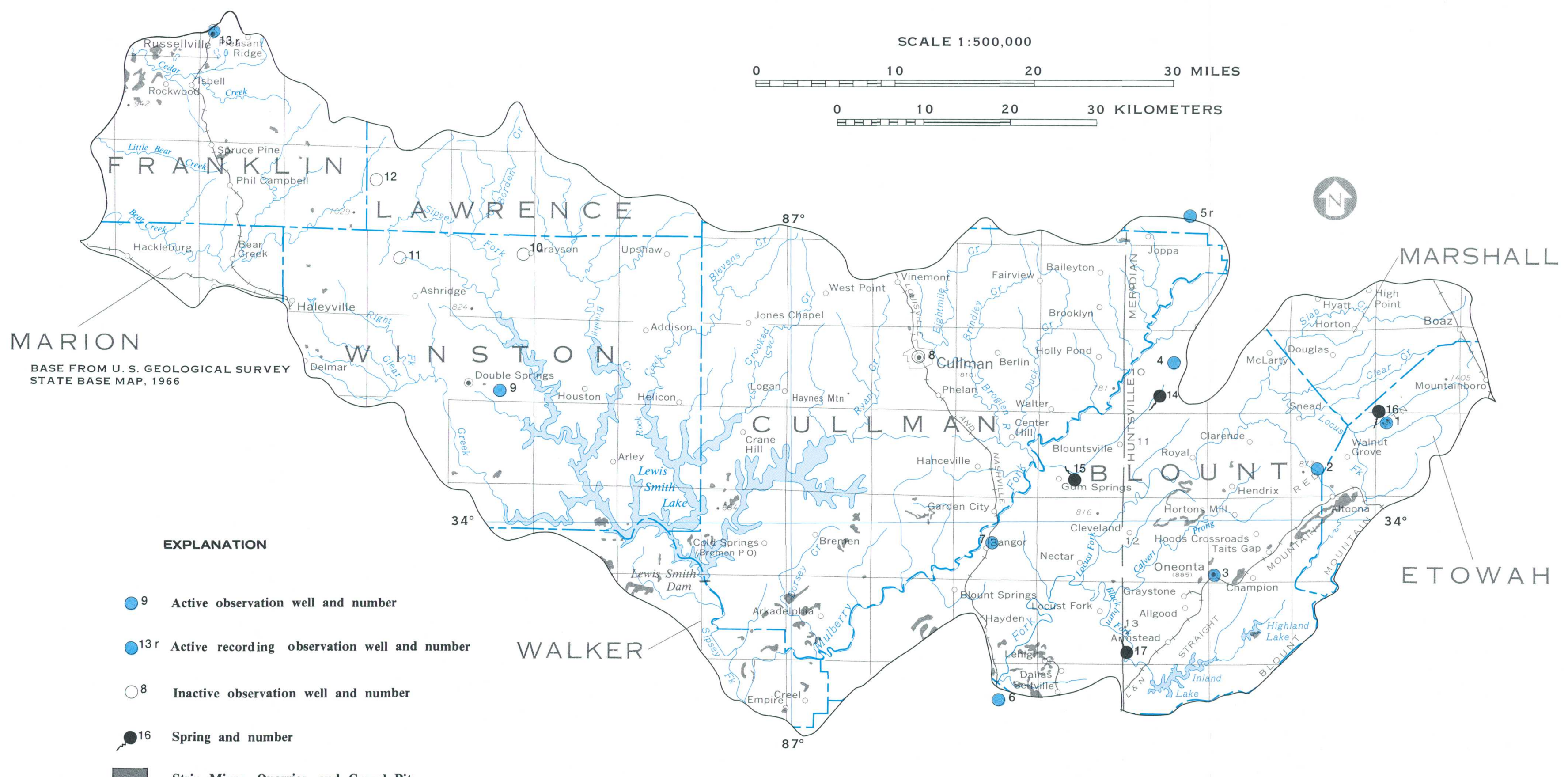

Strip Mines, Quarries, .and Gravel Pits

See Appendix 3 for detailed site description

Figure 4.2-1 Ground-water network 


\title{
5.0 SURFACE WATER \\ 5.I STREAMFLOW CHARACTERISTICS
}

\section{Streamflow Varies Seasonally With Rainfall and Evapotranspiration}

\author{
Variations in streamflow are related to the duration \\ and intensity of rainfall and the seasonal changes \\ in evapotranspiration.
}

The seasonal pattern of streamflow in Area 22 is shown by a sample hydrograph of daily discharge (fig. 5.1-1). This hydrograph was selected because it illustrates all phases of the yearly cycle of streamflow; characteristic low flow during October, the month of lowest average rainfall; increasing flow in November and December as evapotranspiration decreases and the winter rains begin; and high flows from January to April when heavy general rains fall on wet or saturated soil. Flows recede in May and June as rainfall diminishes and evapotranspiration increases; surface runoff from thunderstorm activity in July and early August; and, finally, recession of flow in August and September as rains become less frequent and ground-water outflow becomes the primary source of streamflow.

A streamflow characteristic illustrated by the hydrograph is its wide variability above and below the annual average flow (fig. 5.1-1). The variability of monthly mean streamflow is shown on figure 5.1-2.

A comparison of monthly mean rainfall and runoff is illustrated by figure 5.1-3 for the 30-year base period 1941-70. Evaporation from a free water surface, by months for 1978 is also shown. Limited data are available for evaporation and transpiration from the National Weather Service, Birmingham (see section 2.6). 

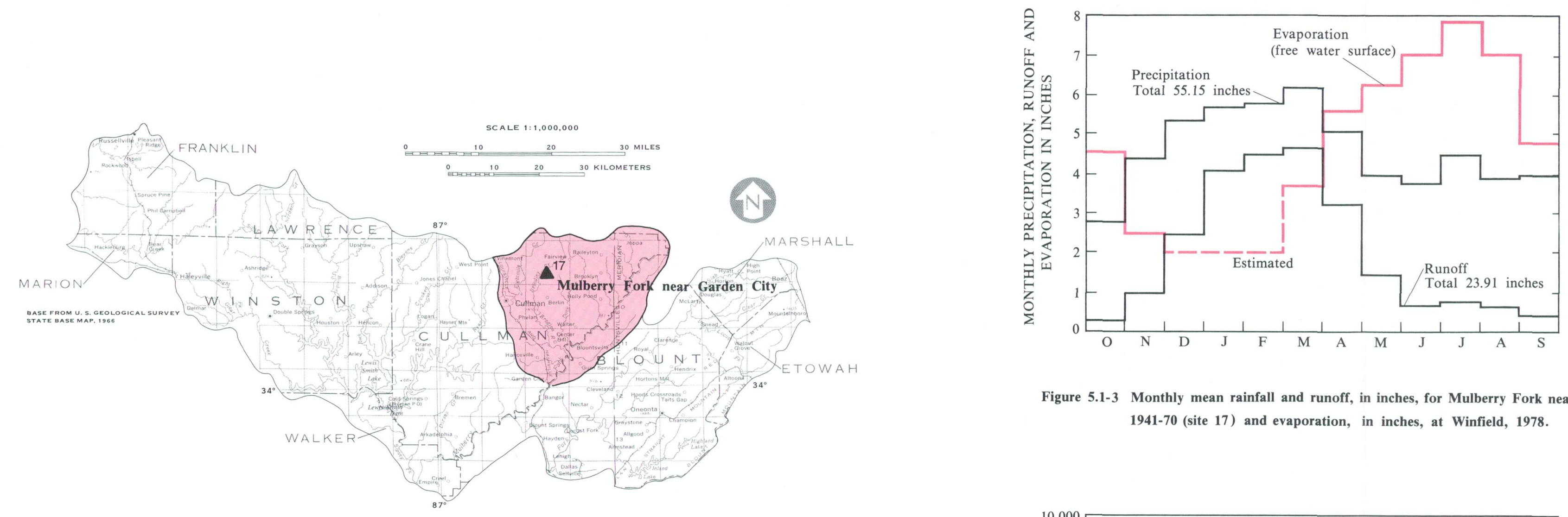

Runoff data for

Mulberry Fork near

Garden City $1941-7$

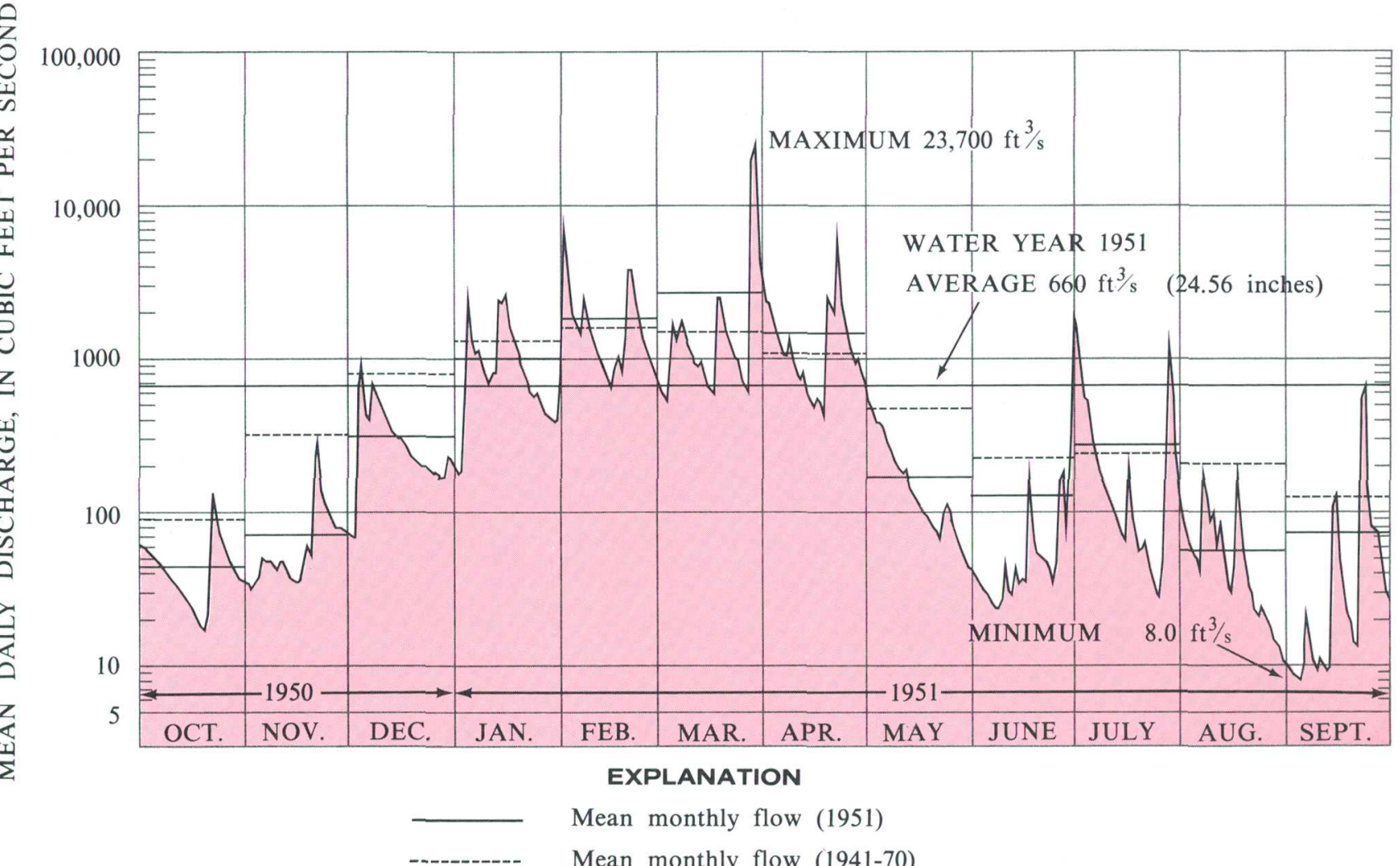

Figure 5.1-1 Daily discharge for Mulberry Fork near Garden City.
Figure 5.1-3 Monthly mean rainfall and runoff, in inches, for Mulberry Fork near Garden City, 1941-70 (site 17) and evaporation, in inches, at Winfield, 1978.

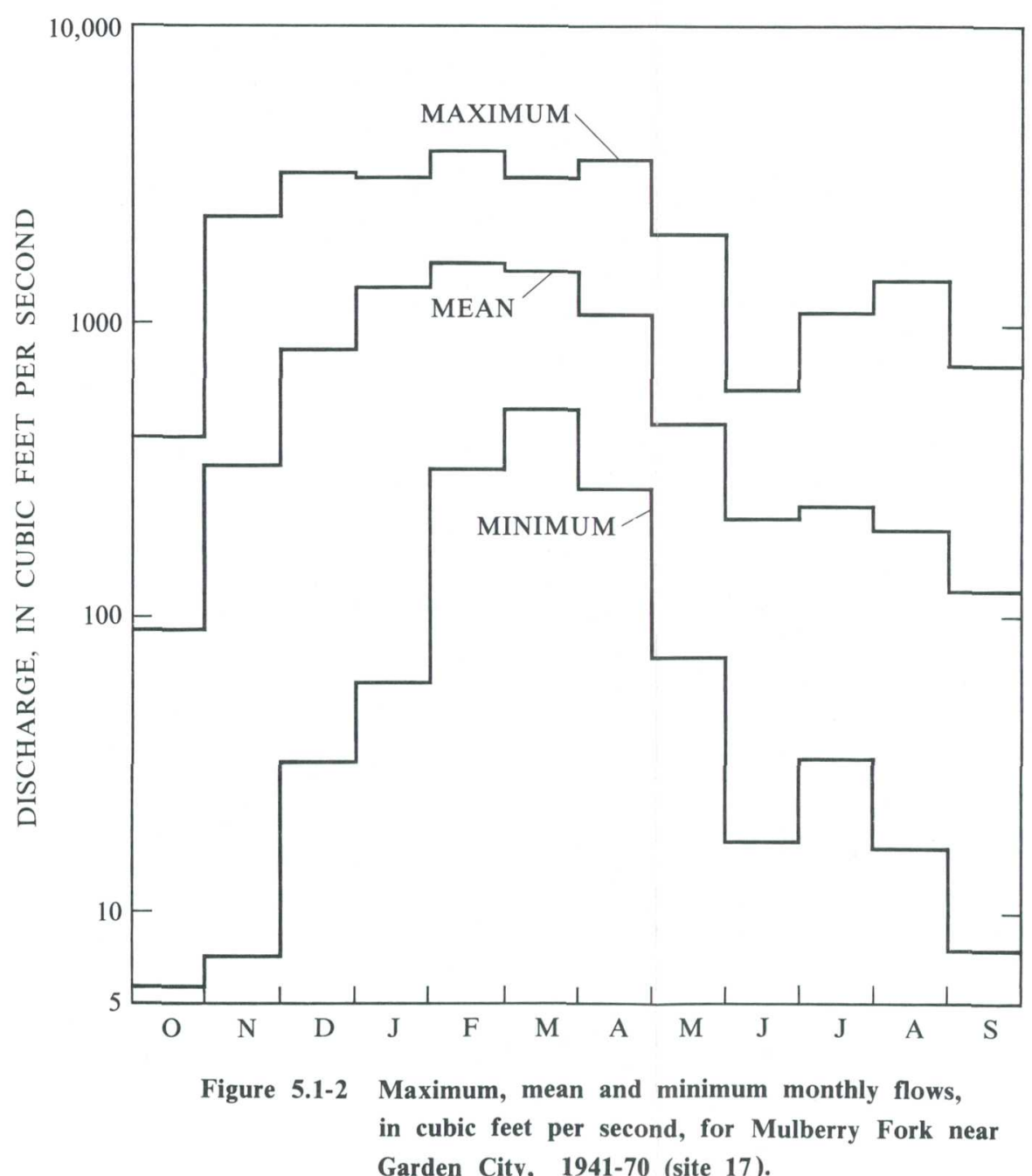

Garden City, 1941-70 (site 17) 


\title{
5.0 SURFACE WATER (Continued) 5.2 LOW FLOW
}

\section{Aquifers in Area 22 Vary Widely in Their Ability to Store and Release Water to Streams}

\author{
Aquifers in Area 22 vary widely in their ability to store water \\ and, consequently, in their ability to provide water to \\ streams during periods of no rainfall.
}

Effective ground-water storage in the Pottsville Formation is small. Thus, discharge of ground water during periods of no rainfall is not sufficient to maintain streamflow and many small streams draining the Pottsville go dry. Conversely the sand and gravel in the Tuscaloosa Group contain large quantities of water where areally extensive and thick. Streams draining small areas entirely in the Tuscaloosa Group have relatively high rates of flow during dry periods. The pre-Pennsylvanian rocks in Area 22 generally contain enough water to maintain streamflow during dry periods. The contrast in the ability of these aquifers to provide water to maintain dry-period flow in streams is illustrated in figure 5.2-1. The low-flow index number, recession index (Bingham, 1979), shown on the map is related to the rate at which streamflow declines in dry weather.

The indices of low flow commonly used in Alabama are the 7-day $\mathrm{Q}_{2}$ and 7-day $\mathrm{Q}_{10}$. The 7-day low flow is the lowest average rate of flow for 7 consecutive days in each year. It will be less than the 7-day $\mathrm{Q}_{2}$ at intervals averaging 2 years in length and less than the 7-day $Q_{10}$ at intervals averaging 10 years in length. The 7-day $Q_{2}$ and 7-day $\mathrm{Q}_{10}$ can be estimated from figure 5.2-2 for drainage basins exceeding $5 \mathrm{mi}^{2}$. The appropriate graph is selected by determining for the area of interest the low-flow index number, drainage area, and average annual precipitation. The top lines of the bars in the graphs are used to determine 7-day $Q_{2}$ or 7-day $Q_{10}$ for areas with 56 inches of annual precipitation, and the bottom lines of the bars are used for areas with 52 inches of annual precipitation. Discharge for drainage basins with intermediate values of annual precipitation can be determined by interpolating between the lines. In the example illustrated for a drainage basin with a low-flow index number of 140 , a drainage area of 23 $\mathrm{mi}^{2}$, and annual precipitation of 54 inches, the 7-day $\mathrm{Q}_{2}$ is $8.5 \mathrm{ft}^{3} / \mathrm{s}$ and the 7 -day $Q_{10}$ is $4.2 \mathrm{ft}^{3} / \mathrm{s}$.

These graphs should not be used beyond the ranges shown nor should they be used for streams where man's activities have substantially affected the flow.

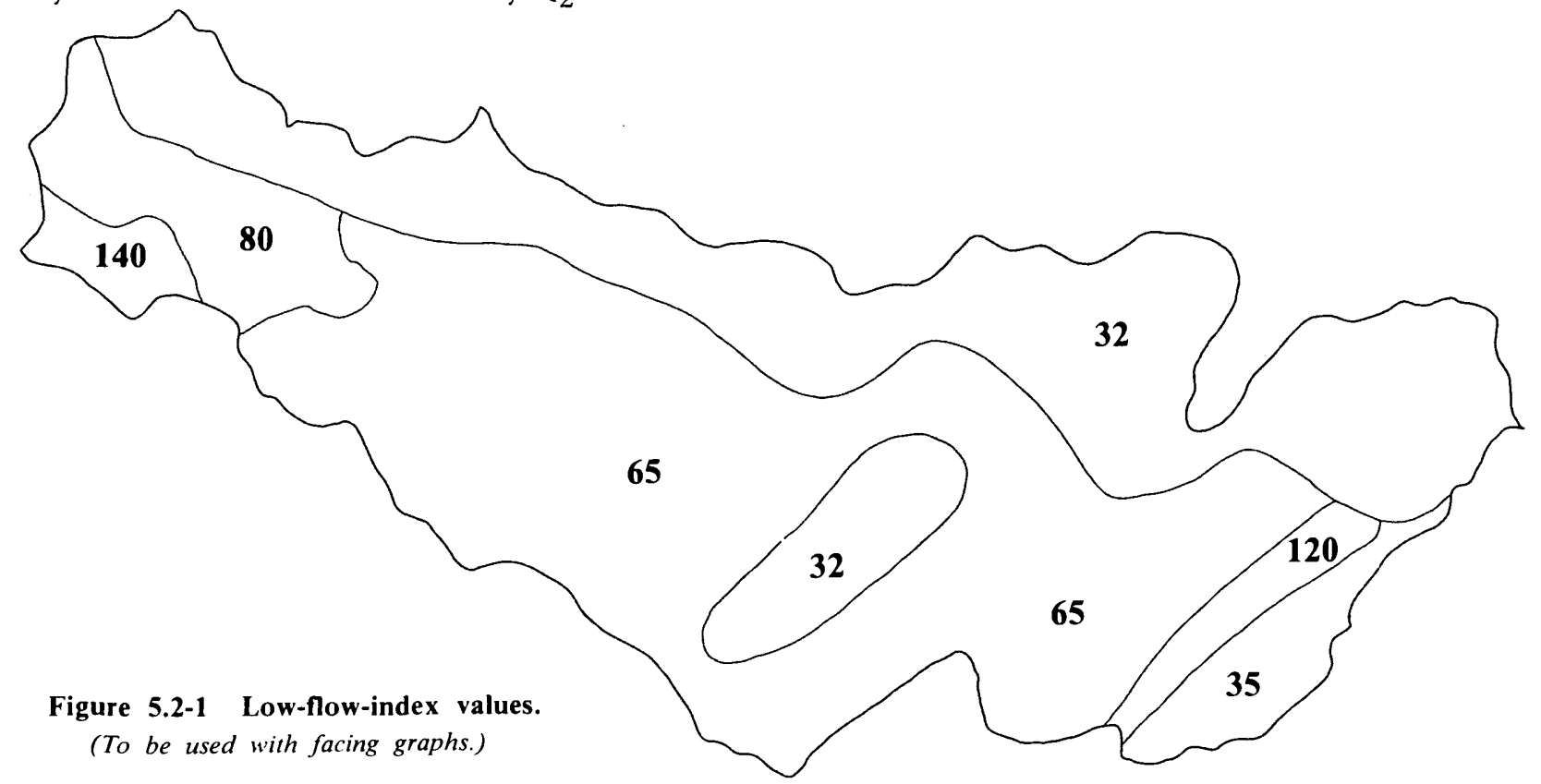




$$
\frac{1}{1}=11
$$




\subsection{SURFACE WATER (Continued) 5.3 FLOOD FLOW}

\section{Flooding Chronic in Area 22}

\section{Natural conditions and cultural activities contribute to chronic flooding in Area 22.}

Chronic flooding as the result of intensive rainfall is a natural characteristic of streams and rivers in Area 22. Floods are influenced by two factors: those relating to land and those relating to climate. Land factors include elevation, slope, soil composition, drainage pattern, and cultural influences. Narrow flood plains and steep slopes are characteristic of the Area. These factors contribute to the rapid accumulation of storm runoff. Climatic factors include seasonal distribution and intensity of storms. Examples of flood flows in response to a storm of unusual rainfall intensity which occurred during April 1979, are shown in figure 5.3-1.

Frequency and seasonal distribution of floods are generally related to climatic factors. Analyses of these characteristics for which data are applicable to Area 22 are contained in reports by Peirce (1954), Gamble (1965), Hains (1973), and Olin and Bingham (1977).
Equations for estimating flood frequency of ungaged sites on unregulated streams draining from 1 to $15 \mathrm{mi}^{2}$ are contained in "Flood Frequency of Small Streams in Alabama" HPR No. 83 (Olin and Bingham; 1977).

Most of the flood damage in Area 22 is to farmlands, roads, and bridges in rural valleys with narrow flood plains and steep slopes. Damage also occurs near cities and towns where encroachment on the flood plains by industrial, commercial, and residential development is most prevalent. Topographic maps in Area 22 for which flood-prone areas have been estimated are on figure 5.3-2. These maps are available from either the U.S. Geological Survey, P. O. Box V, University, Ala. 35486 or the Alabama Office of State Planning and Federal Programs, Alabama State Planning Division, State Capitol, Montgomery, Ala. 36130. 


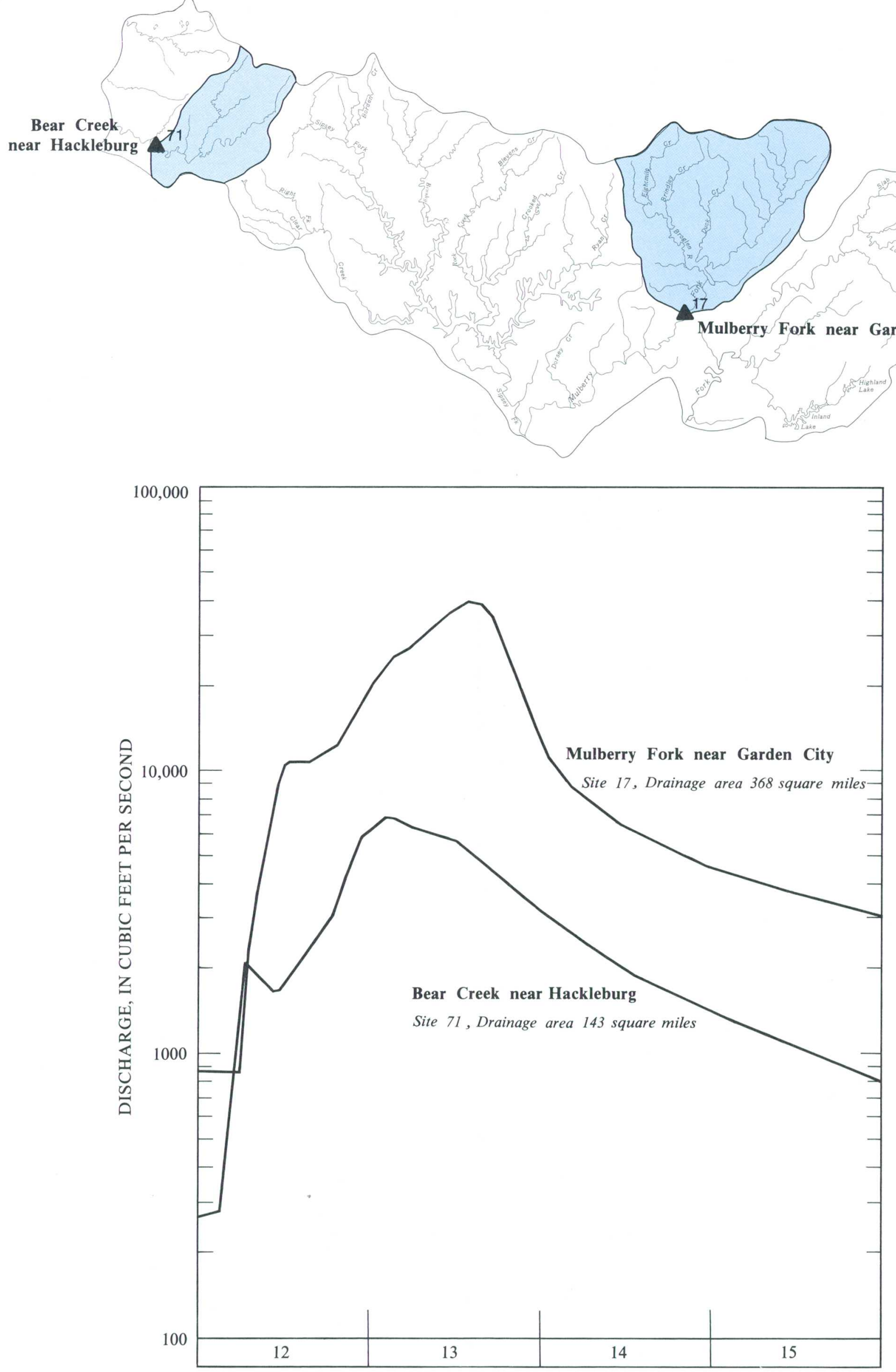

Figure 5.3-1 Flood Hydrographs, April 12 to 15, 1979.

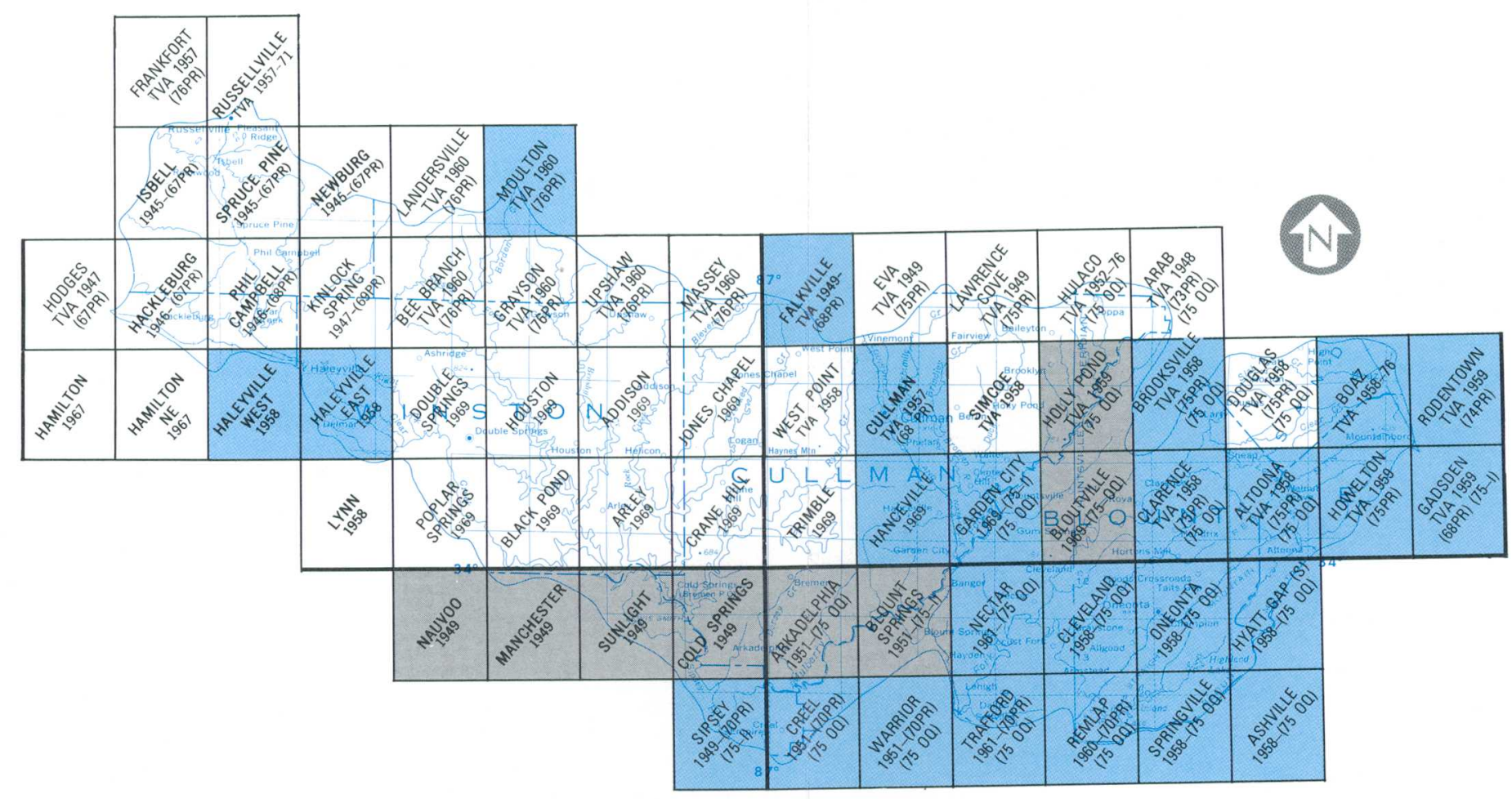

EXPLANATION

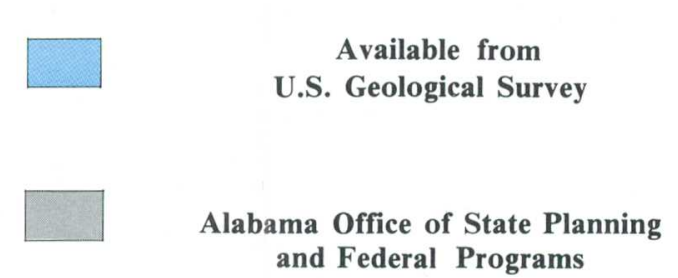

Figure 5.3-2 Maps of flood-prone areas.
5.0 SURFACE WATER (Continued) 5.3 FLOOD FLOW 


\title{
5.0 SURFACE WATER (Continued) 5.4 DURATION OF FLOW
}

\section{Most Streams Poorly Sustained}

\author{
Streams draining outcrop areas of the Pottsville Formation and \\ pre-Pennsylvanian rock in Area 22 are poorly sustained in \\ comparison with those draining areas of outcrop of the \\ Tuscaloosa Group.
}

Differences in streamflow for three gaging stations in Area 22 are illustrated by flow-duration curves (fig. 5.4-2). These curves are based on streamflow for the period 1958-79 for each station and plotted in unit runoff (cubic feet per second per square mile) for a more direct comparison. The probability scale is used for the time axis and shows the percentage of time that a specific discharge can be expected to be equaled or exceeded.

Because basin characteristics are so clearly portrayed by the flow-duration curves, the curves for three streams draining areas of varying sizes and types of geologic outcrops are used to illustrate the effects of geology on streamflow (fig. 5.4-2). Their locations are shown on figure 5.4-1.

Three major geologic units cropping out in the area Tuscaloosa Group, Pottsville Formation, and prePennsylvanian rocks (fig. 5.4-1). The Pottsville Formation consists of relatively impermeable shale, siltstone, and sandstone. In contrast, the Tuscaloosa Group contains permeable beds of sand and gravel and the pre-Pennsylvanian rocks consist of permeable limestone and dolomite.
The flow-duration curves reflect the effects of permeable or impermeable land surface and the ability of the ground-water reservoirs to release water to streamflow. In the Bear Creek basin the curve depicts the characteristics of the Tuscaloosa Group to absorb rainfall (recharge) and release water during rainless periods (low flow). The curve for Mulberry Fork depicts the impermeable effect of the Pottsville Formation. The curve for Locust Fork depicts the effect of the Pottsville Formation and the effect of the pre-Pennsylvanian rocks which readily accepts recharge and the water moves downdip (southwest) along the aquifers to areas outside the basin.

As a hydrologic tool, the flow-duration curve provides a convenient means of appraising the discharge characteristics of a stream. The slope of the flowduration curve is a measure of the variability of flow-the steeper the slope, the greater the variability. A flat slope usually indicates the presence of storage, which tends to minimize the range of flow. This storage may be either on the surface in lakes, ponds, swamps, or in the ground as ground-water storage. 


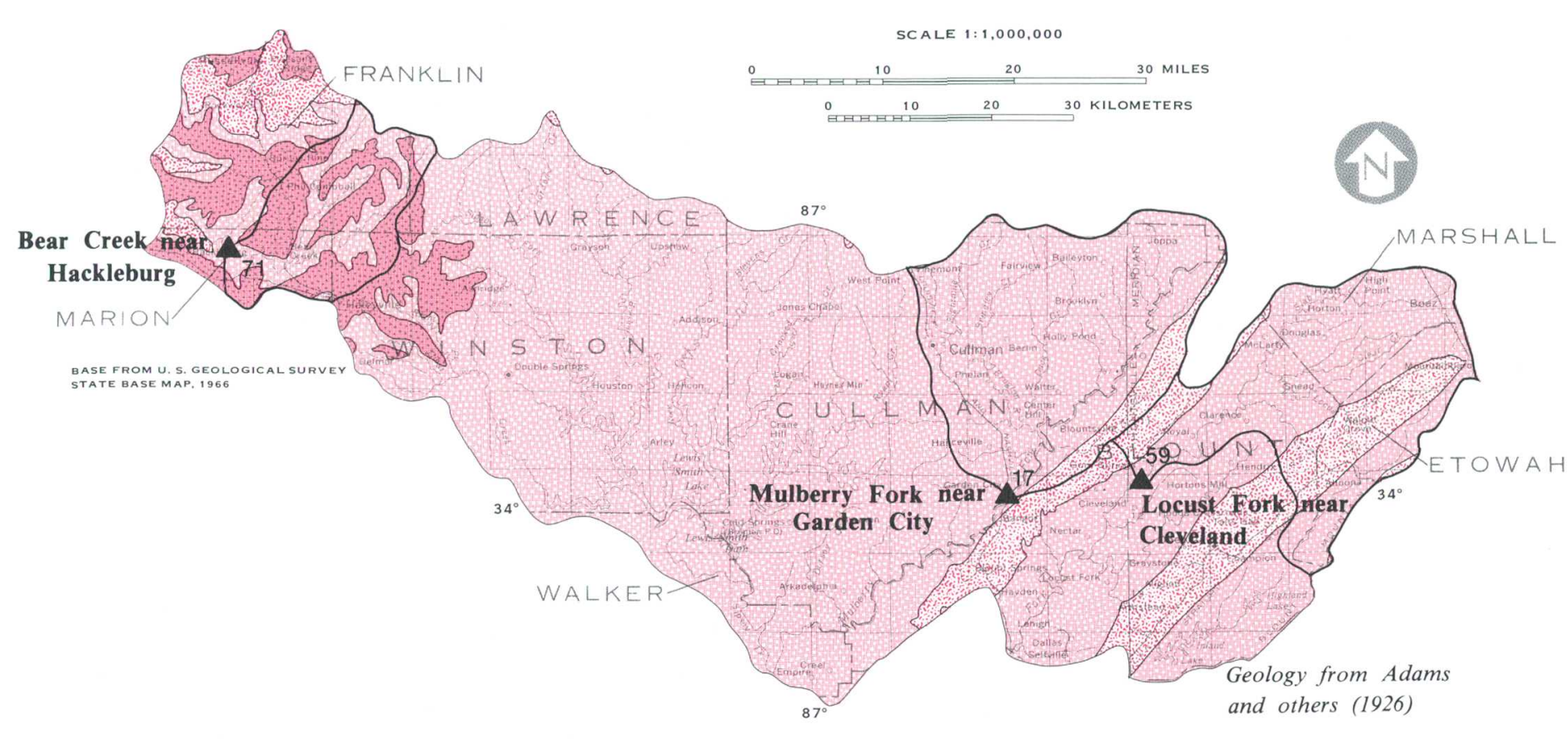

EXPLANATION

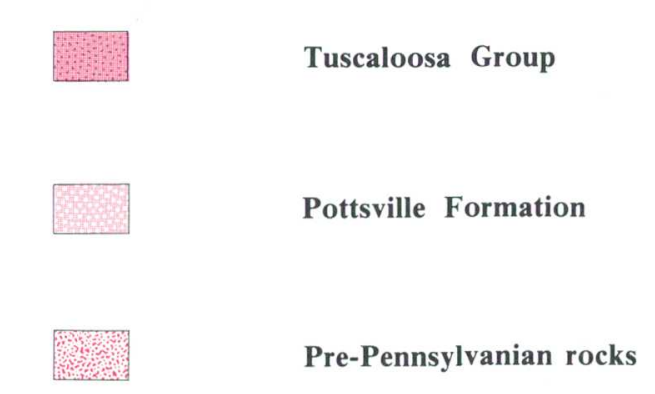

Figure 5.4-1 Geologic map showing drainage areas for selected gaging stations.

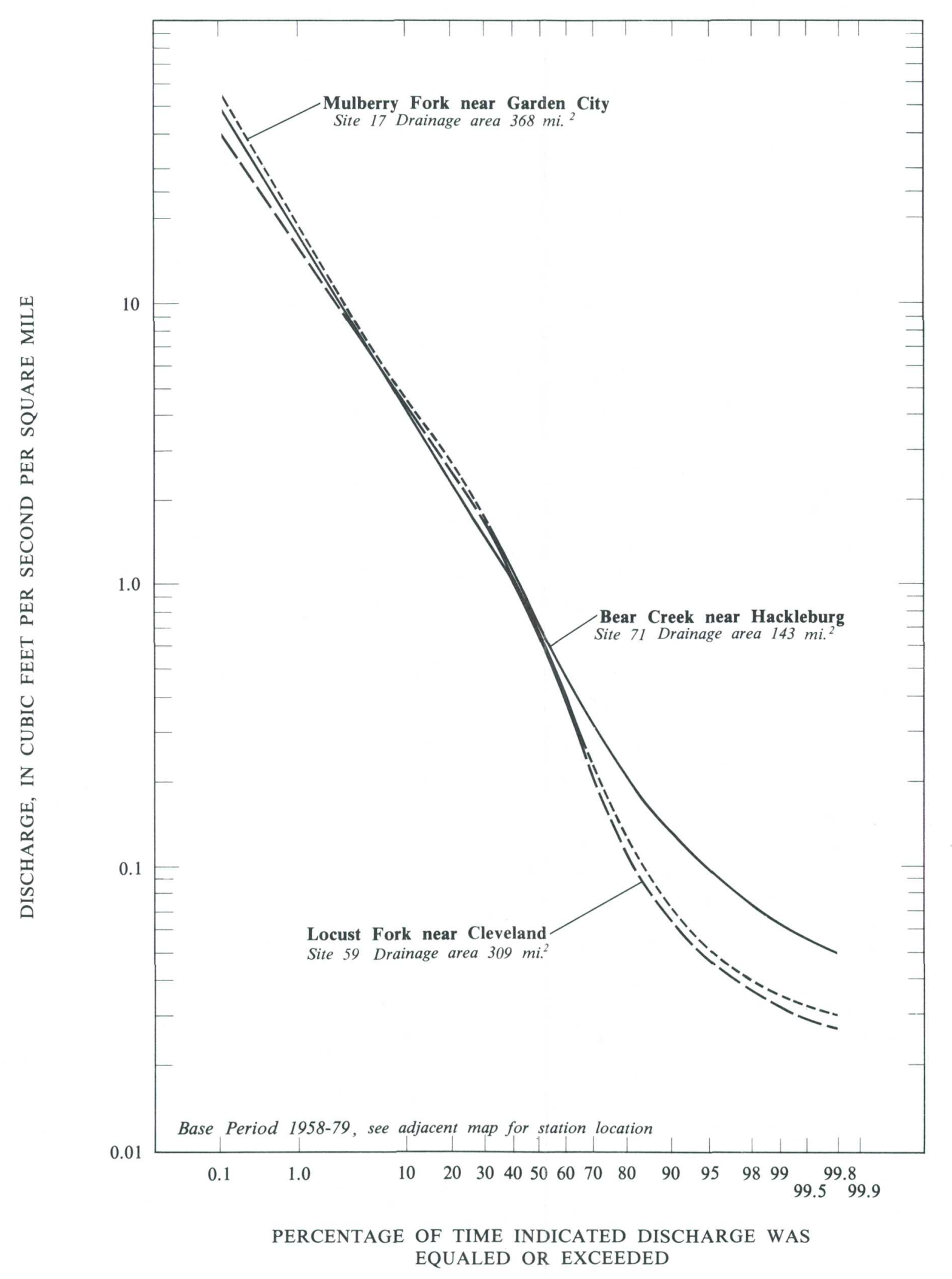

Figure 5.4-2 Representative flow-duration curves.

5.0 SURFACE WATER (Continued) 


\title{
Specific Conductance and Dissolved-Solids of Water are Low Except in Coal-Mine and Industrial Areas
}

\author{
Mineralization of surface water resulting from coal-mining and \\ industrial activity is reflected by an increase in specific \\ conductance and dissolved solids.
}

\begin{abstract}
Specific conductance of water is a measure of the ability of water to conduct an electric current. Because it is directly related to dissolved-solids content, it serves as an indicator of the degree of mineralization in water and commonly is used to estimate specific ion concentrations.
\end{abstract}

Specific conductance of surface water in Area 22 usually is low (fig. 6.1-1), except locally in areas of industrialization and coal mining. Streams in and near the city of Cullman and surrounding communities typically have higher specific conductances that reflect industrial-waste discharges. In other areas, higher specific conductance generally indicates coal-mine drainage.

Dissolved-solids content of water in streams usually is derived from soluble minerals in soil and geologic strata underlying the basin. The range of specific conductance generally observed in streams draining relatively undisturbed basins in the area are shown in figure 6.1-1. Factors are also shown that, when multiplied by specific conductance, provide an estimate of the dissolved-solids concentration (Cherry, 1963). Water in streams draining the Tuscaloosa Group and the Pottsville Formation (fig. 6.1-1) are very low in mineral content, reflecting the relatively insoluble strata (unconsolidated sand and gravel and indurated sandstone and shale) of the formations. Greater mineral content of water in streams draining the pre-Pennsylvanian rocks is due to the higher solubility of the carbonate strata (limestone and dolomite).

Relations between specific conductance and stream discharge draining undisturbed basins in each of the three geologic units in the area are illustrated in figure
6.1-2. Knowing the stream discharge this graph may be used to estimate specific conductance in streams draining unmined basins in Area 22. Specific conductance is generally higher during low-flow periods because of prolonged contact of water with soluble minerals in soils and rocks and less water available for dilution. During high-flow periods specific conductance is generally lower because of dilution by surface run off.

Accelerated weathering of pyritic and other minerals present in coal-mine spoils results in the dissolution of large quantities of minerals and the production of sulfuric acid. These are contributed to streamflow draining mined areas. The acidic water reacts with other minerals increasing the dissolved-solids concentrations as well as specific conductance. Increases in specific conductance in streams draining mined areas are shown in figure 6.1-3. The specific conductance of water in Dorsey Creek at a discharge of $1.0 \mathrm{ft}^{3} / \mathrm{s}$ at site 22 (downstream from mined areas), is approximately six times greater than at site 21 (upstream from mined areas).

Specific conductance observed in streams draining mined areas in Area 22 generally ranges from 30 to 800 umhos $/ \mathrm{cm}$. In and immediately downstream from mined areas, the specific conductance of mine drainage can be as high as 3,000 umhos $/ \mathrm{cm}$. In general, specific conductance of water draining mined areas is highly variable and depends on such factors as: (1) the presence of pyritic and other minerals in spoil material, (2) the length of time of exposure of these minerals to weathering by air and water, and (3) the quantity of water leaving the mined area. Highly mineralized water draining mined areas is usually local and generally decreases in downstream areas because of dilution. 


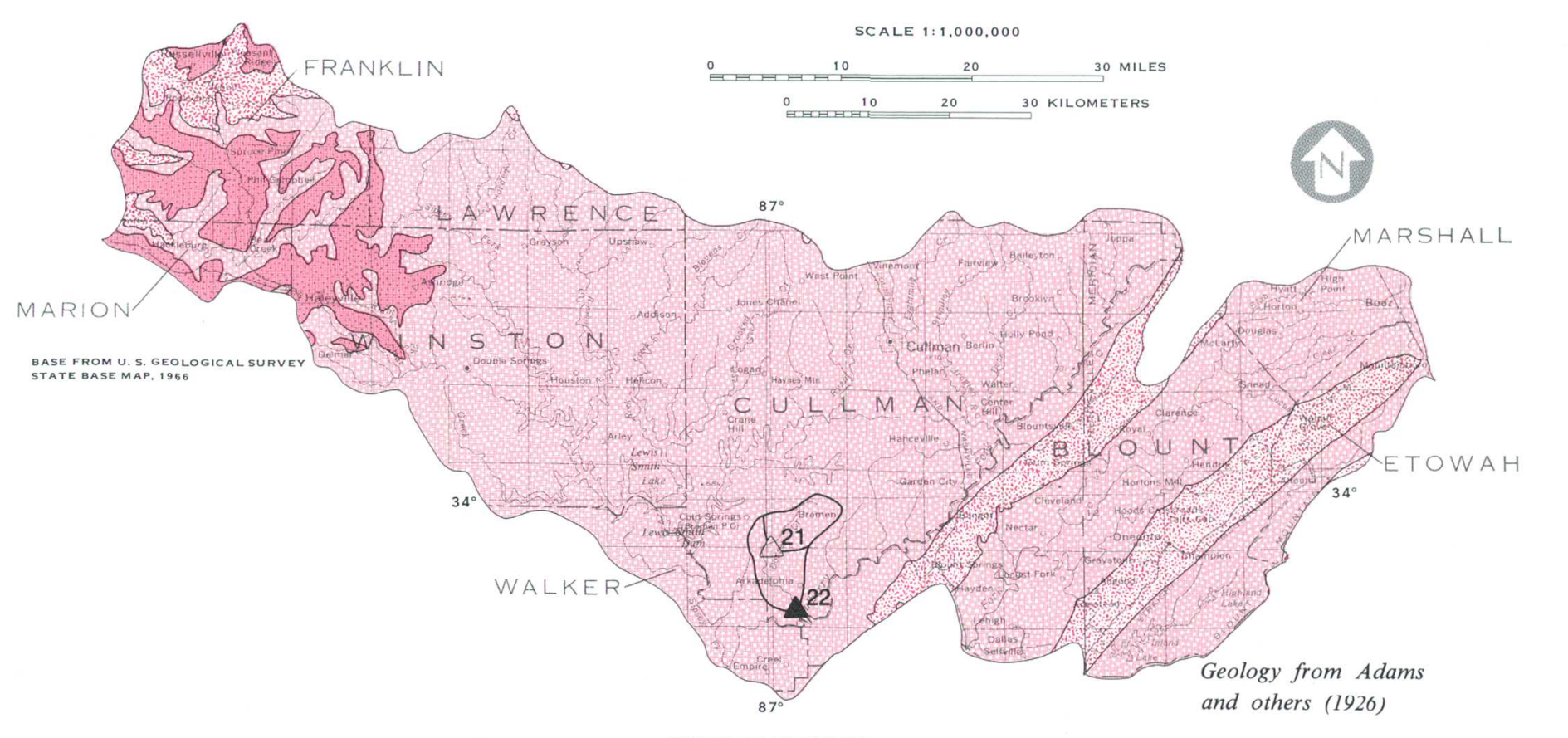

EXPLANATION

Specific Conductance
In micromhos per centimeter micromhos per cen
at 25 celsius

Geologic Formation

25 celsis

10-30

20-120

$80-350$

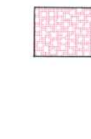

-

Factors applied to specific conductance for$$
\text { In milligrams per liter }
$$
(issolved-solids concentration

$$
\begin{aligned}
& 0.90 \\
& 0.68 \\
& 0.60
\end{aligned}
$$

$\Lambda^{22}$ Mined site and number

$\triangle^{21} \quad$ Unmined site and number

Figure 6.1-1 Specific conductance in streams draining undisturbed areas.

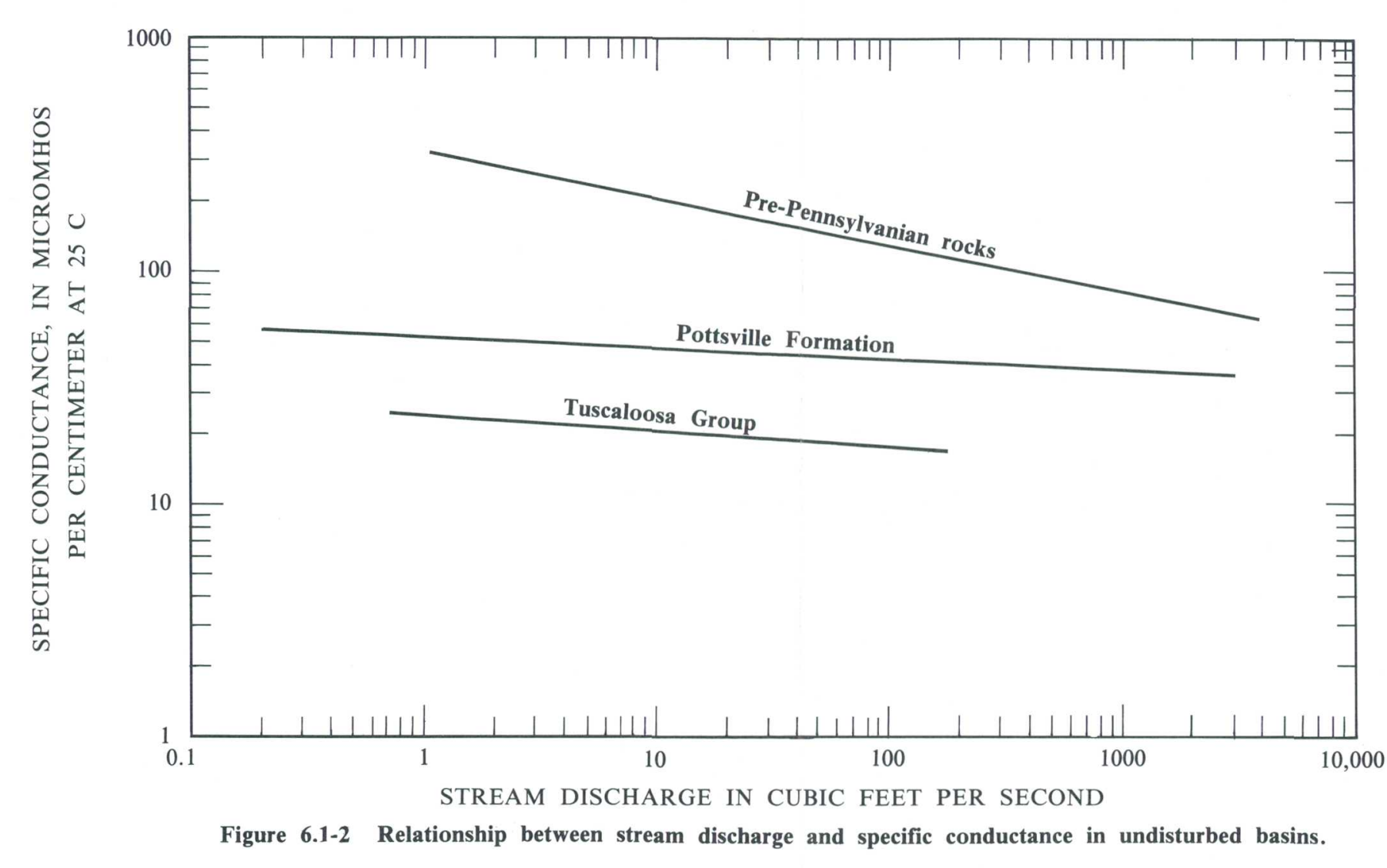

Figure 6.1-2 Relationship between stream discharge and specific conductance in undisturbed basins.

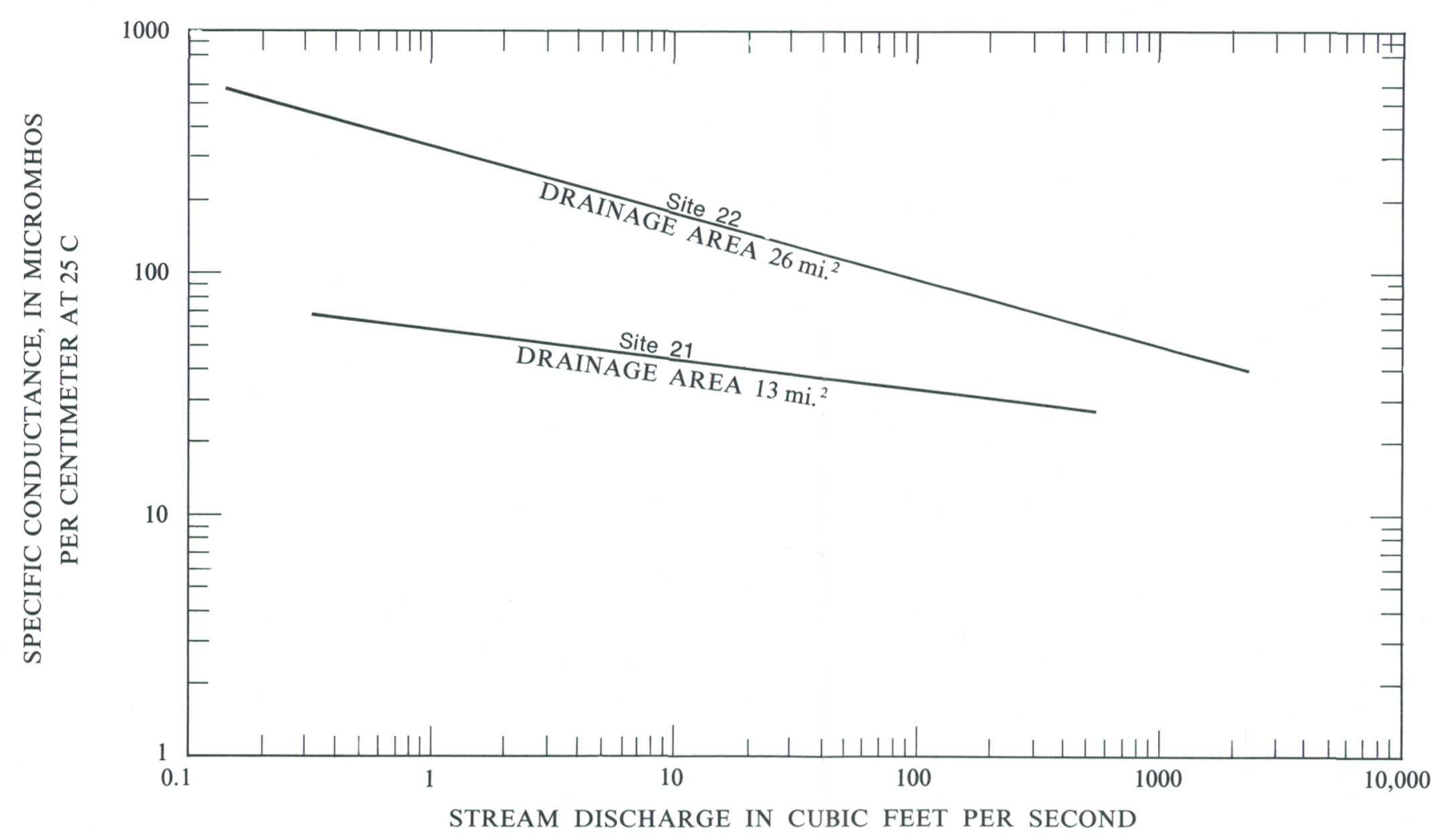

Figure 6.1-3 Relationship between stream discharge and specific conductance in Dorsey Creek. 


\subsection{QUALITY OF SURFACE WATER (Continued) $6.2 \mathrm{pH}$}

\section{pH of Streamflow Usually Fluctuates in Near Neutral Range}

\section{The $\mathrm{pH}$ of water in streams usually fluctuates in the near neutral range (6.0-8.0 units) and generally is not lowered by mine drainage.}

\begin{abstract}
A $\mathrm{pH}$ value of 7.0 represents neutral water. Values less than 7.0 denote acidic water and values greater than 7.0 denote alkaline water. The $\mathrm{pH}$ of water exerts a strong influence on the suitability of water for industrial, municipal, and recreation purposes. Prolonged extreme $\mathrm{pH}$ levels ( $\mathrm{pH}$ less than 5.5 and greater than 9.0) can significantly affect aquatic productivity, corrosivity, and the toxicity, mobility, and solubility of many chemical compounds.
\end{abstract}

In unmined areas, the $\mathrm{pH}$ of water is primarily controlled by the presence of dissolved carbon dioxide and/or the hydrolysis of salts of weak acids and strong bases. Sources of these substances generally include rainfall, weathered geologic strata, and decomposition of organic matter in soils. The range of $\mathrm{pH}$ values generally observed in streams draining undisturbed basins is shown on figure 6.2-1. The $\mathrm{pH}$ of water in streams varies widely, but usually is in the near neutral range (6.08.0 units). Fluctuation of $\mathrm{pH}$ is generally related to one or more environmental factors such as geology, streamflow, and land use (Kaufman, 1970). The influence of geology on the $\mathrm{pH}$ of water in streams draining the area is shown in figure 6.2-1. The highest $\mathrm{pH}$ values generally occur in streams primarily underlain by carbonate strata such as limestone and dolomite of the pre-Pennsylvanian rocks; water in these streams is alkaline with a high neutralization capacity. The lowest $\mathrm{pH}$ values generally occur in streams underlain by unconsolidated sand and gravel of the Tuscaloosa Group; water in these streams usually is acidic with low neutralization capacity. Near neutral $\mathrm{pH}$ values generally occur in streams in the Pottsville Formation, an area primarily underlain by sandstone and shale.

$\mathrm{pH}$ values generally decrease with increased streamflow. During low flow the $\mathrm{pH}$ values in streams approach that of water in aquifers underlying the basin, while during high flow the $\mathrm{pH}$ values approach those of overland runoff. Overland runoff, in Area 22, is generally acidic because of acidic precipitation and a carbon dioxide and organic-rich soil environment.

In coal mine areas the $\mathrm{pH}$ of mine effluent is determined by the chemical character of spoil. In some areas, weathering of pyrite and other sulfate-bearing minerals results in the production of sulfuric acid. Acid-mine drainage may have $\mathrm{pH}$ values that range from 2.0 to 5.0 units. In many areas, calcareous minerals such as siderite, calcite, and ankarite commonly occur in large quantities in spoil. In these areas, acidic mine drainage is rapidly neutralized. 


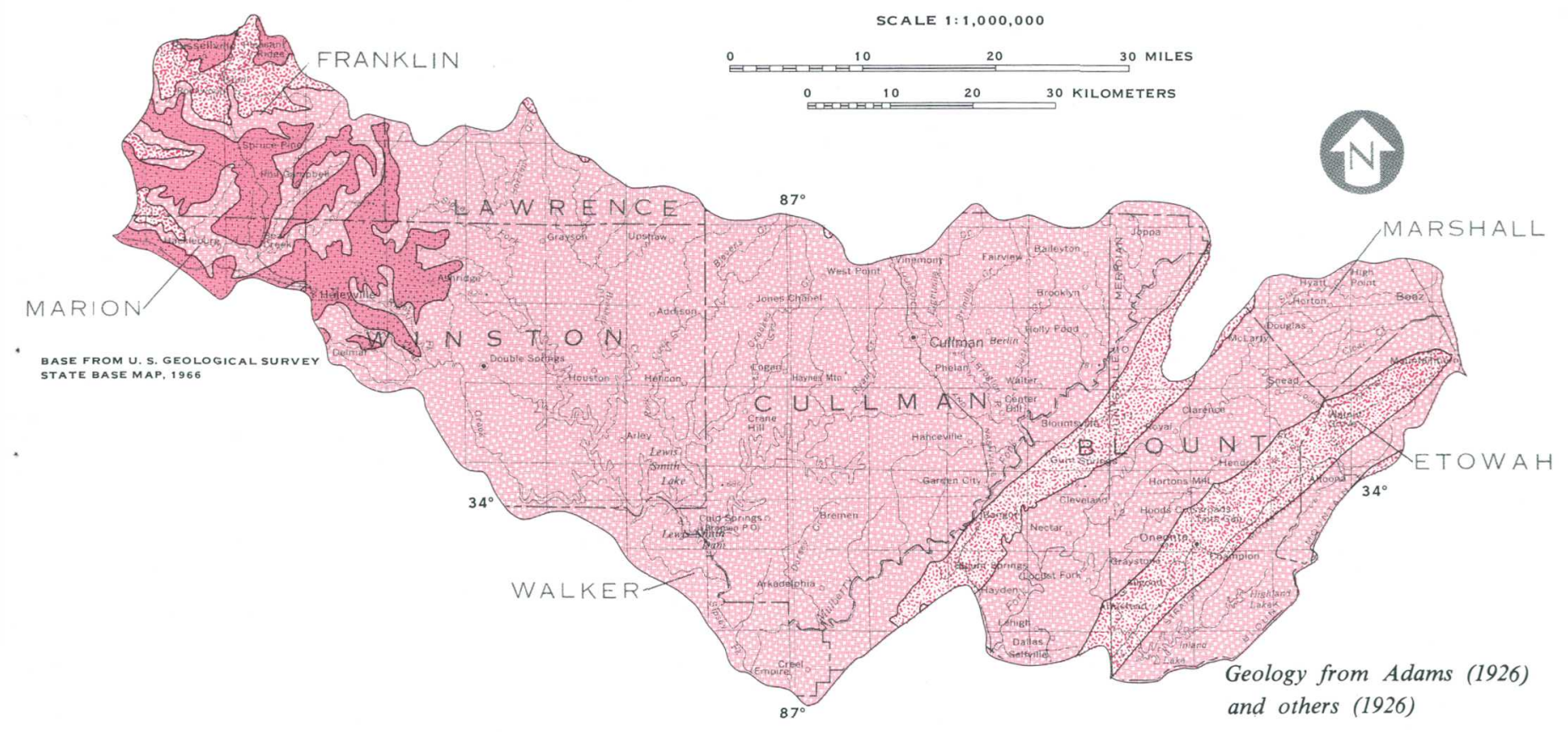

EXPLANATION

\section{General pH range}

\section{5-7.5 Tuscaloosa Group}

6.0-8.0 Pottsville Formation

6.5-8.5 Pre-Pennsylvanian rocks

Figure 6.2-1 $\mathrm{pH}$ in streams draining undisturbed basins. 


\title{
6.0 QUALITY OF SURFACE WATER (Continued) 6.3 SEDIMENT
}

\section{Surface Mining Drastically Alters Natural Sediment Yield}

\author{
Sediment yields from undisturbed basins generally range \\ from 20 to 800 (tons $/ \mathrm{mi}^{2}$ ) $/ \mathrm{yr}$ while those from mined \\ basins can be as high as 300,000 (tons $/ \mathrm{mi}^{2}$ )/yr.
}

\begin{abstract}
Annual sediment yields of streams draining relatively undisturbed basins in Area 22 are usually low and may range from 20 to 800 (tons $/ \mathrm{mi}^{2}$ )/ yr. Land-use activities such as forest clearing, cultivation, road construction, and surface mining drastically alter natural erosion and sediment yields. During surface mining, large volumes of exposed unconsolidated spoil may be a major source of sediment. In heavily mined but unreclaimed areas, sediment yields can be as high as 300,000 (tons/mi $\left.{ }^{2}\right) / \mathrm{yr}$ (Hubbard, 1976). Although sediment yields associated with surface mining can be high, they can be reduced by effective reclamation.

Basins in most of Area 22 are underlain by geologic formations (Pottsville and Tuscaloosa Group) characterized by hilly terrains with moderate to steep slopes and easily erodible soils. These characteristics tend to produce rapid runoff with high erosion potential. Most of the area, however, has a dense forest cover which lowers runoff velocities and decreases the influence of topography on erosion and sediment yields.
\end{abstract}

Suspended-sediment concentration ranges, estimated annual sediment yields, and drainage areas for sites 22 and 23 are shown in figure 6.3-1. The sites are located in an area of similar climate and topography and are underlain by the Pottsville Formation, but drain areas of different land use. Site 23 drains a relatively undisturbed basin; site 22 drains a basin with considerable active surface mining and areas under cultivation. The difference in land use in the basins is reflected by the relative positions of their respective sediment yield curves (fig. 6.3-2). During 1979 the annual sediment yield at site 22 was about seven times greater than at site 23. Most of the sediment loads were transported during high flow periods. In general, the highest suspendedsediment concentrations occur during high flow and the lowest during low flow.

Particle-size distribution of suspended sediment transported during high flows occurring on April 11-13, 1979 at site 22 was about 40 percent clay and silt (finer than $0.062 \mathrm{~mm}$ ) and 60 percent sand $(0.06-2.0 \mathrm{~mm})$. This particle-size distribution reflects the lithologic character (fine-grained sandstone) of the Pottsville Formation in the basin.

Bed-material size composition at site 22 averaged 0 percent for clay and silt, 90 percent for sand, and 10 percent for gravel $(2.0-6.4 \mathrm{~mm})$.

Bedload, the sediment transported along and immediately adjacent to the streambed, is unmeasured at sites 22 and 23 and is not included in reported sediment yields. 

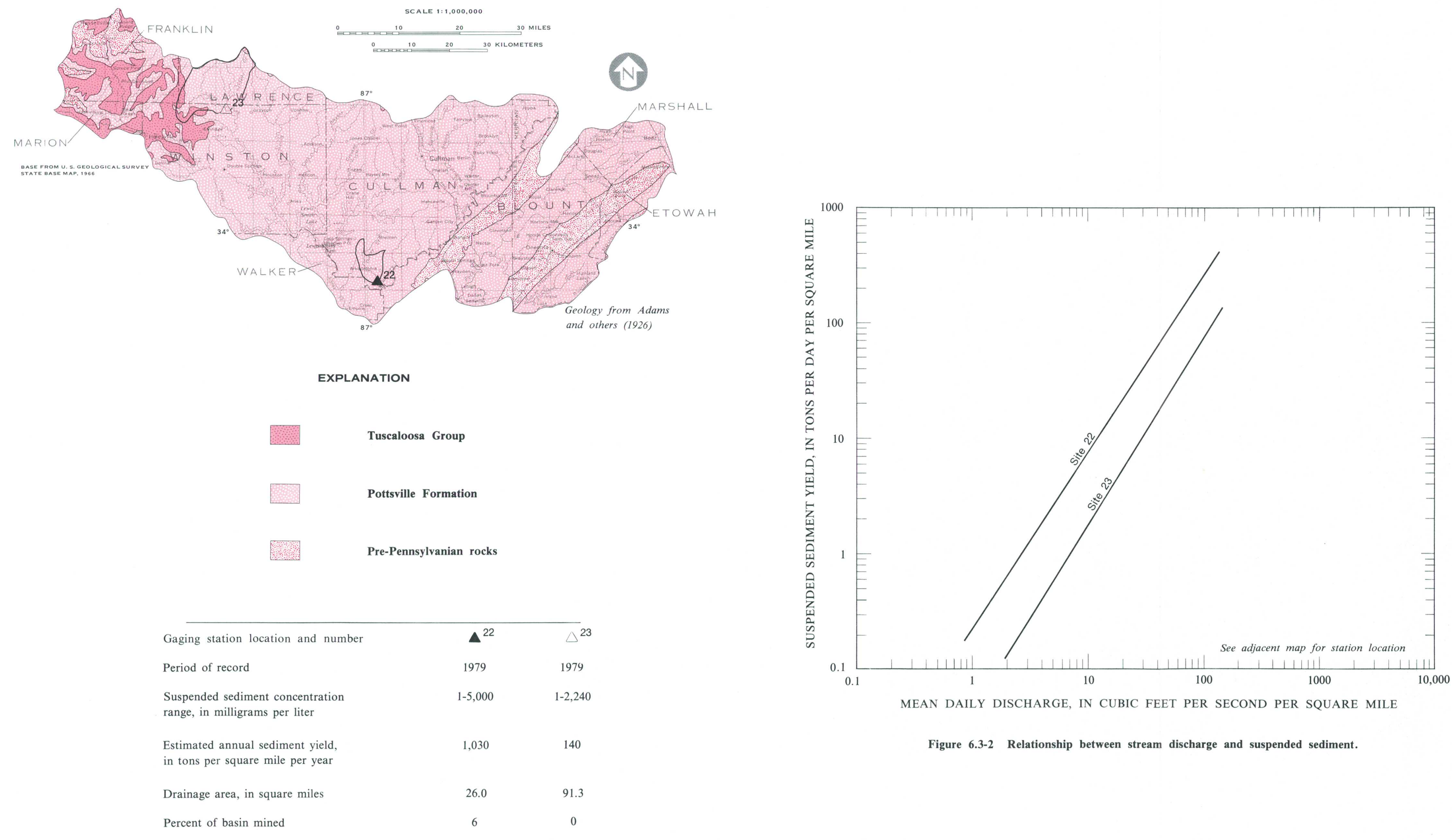

MEAN DAILY DISCHARGE, IN CUBIC FEET PER SECOND PER SQUARE MILE

Figure 6.3-2 Relationship between stream discharge and suspended sediment. 


\title{
Dissolved Iron Concentrations of Streams Draining Mined and Unmined Basins are Similar, but Total Recoverable Iron Concentrations are Markedly Different
}

\author{
The similarity of dissolved iron in streams draining mined and unmined basins \\ is due to aeration of the otherwise high dissolved iron content of mine \\ effluent forming an insoluble precipitate that results in a reduction in \\ dissolved iron but does not change the total recoverable iron \\ concentration.
}

Dissolved-iron concentrations in streams draining mined areas are generally similar to those in streams draining unmined areas in Area 22. Ranges and mean values of observed dissolved-iron concentrations in streams draining mined and unmined basins are shown in figures 6.4-1 and 6.4-2. Dissolved-iron concentrations in streams draining relatively undisturbed basins in Area 22 are generally less than $300 \mu \mathrm{g} / \mathrm{L}$ (micro-grams per liter). Dissolved-iron concentrations exceeding $300 \mu \mathrm{g} / \mathrm{L}$ impart an objectionable taste to water, cause staining, and generally limit the water's use for many domestic and industrial purposes. Sources of iron in water generally include soils rich in organic material and ironbearing minerals in geologic strata underlying the basins. Large quantities of soluble iron salts can be contributed to streamflow from coal-mine spoils as a result of accelerated weathering of iron-bearing minerals such as pyrite and marcasite.

Although dissolved-iron concentrations are generally high in mine effluent, aeration and dilution rapidly decrease the high dissolved iron. Hence, in nearby downstream areas, dissolved-iron concentrations are generally similar to or even less than those in streams draining unmined areas. In contrast, total recoverableiron concentrations are higher in streams draining mined areas and increase with increases in suspended-sediment concentrations.

Aeration of mine drainage with high dissolved-iron concentrations results in the formation of insoluble iron precipitates ("Yellow Boy") that can be observed coating stream bottoms and banks in many mined areas. Sorption of these precipitates on stream sediments results in high total recoverable-iron concentrations (dissolved and suspended in a water-suspended sediment solution). Relations between total recoverableiron concentrations and suspended-sediment concentrations in streams draining mined and unmined basins are shown in figure 6.4-3. These relations may be used for estimating iron loads from mined and unmined basins in the area. High suspended-sediment concentrations generally occur during high streamflow periods and low concentrations occur during low flow. During low flow, total recoverable-iron concentrations are nearly the same as dissolved concentrations. 


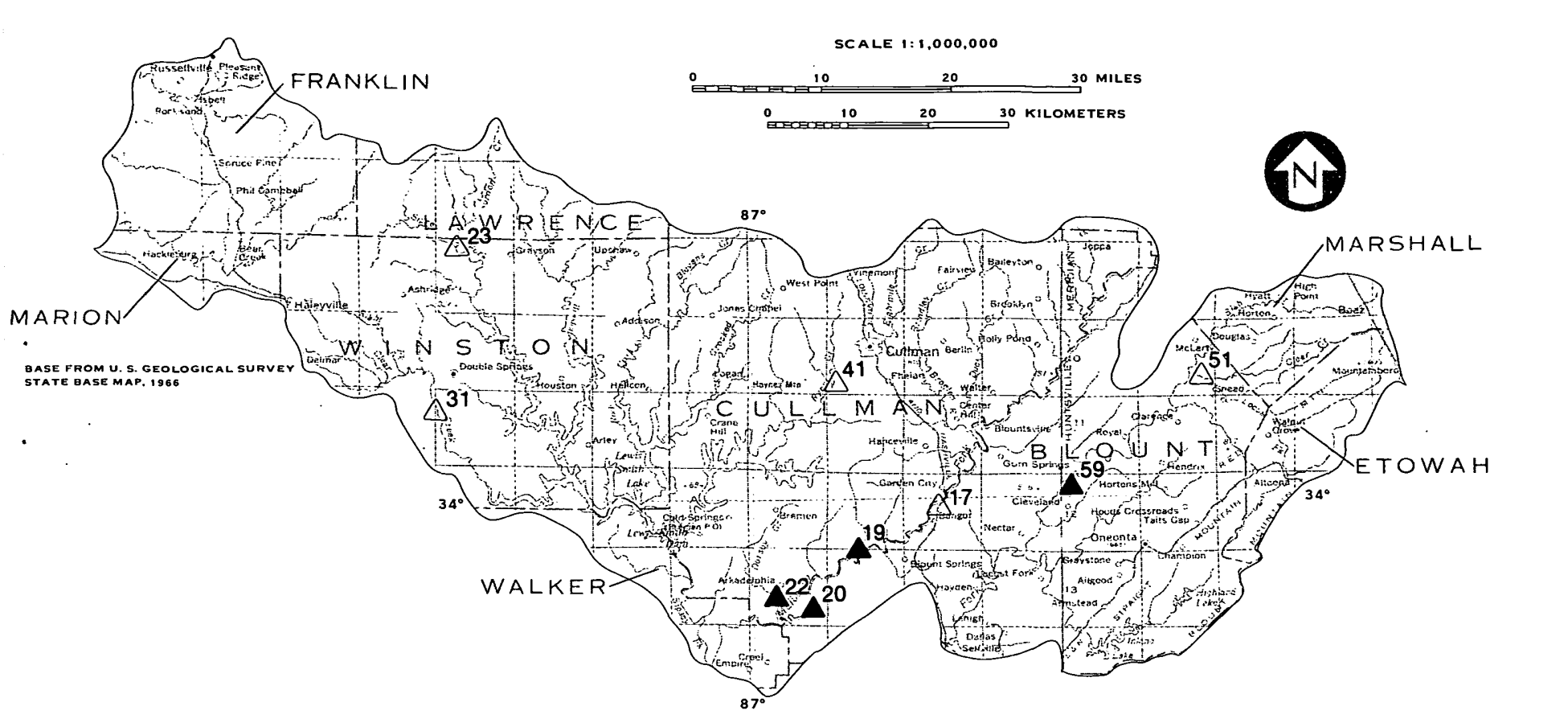

EXPLANATION

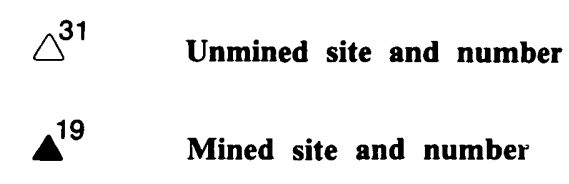

Figure 6.4-1 Location of selected sites for iron concentrations.

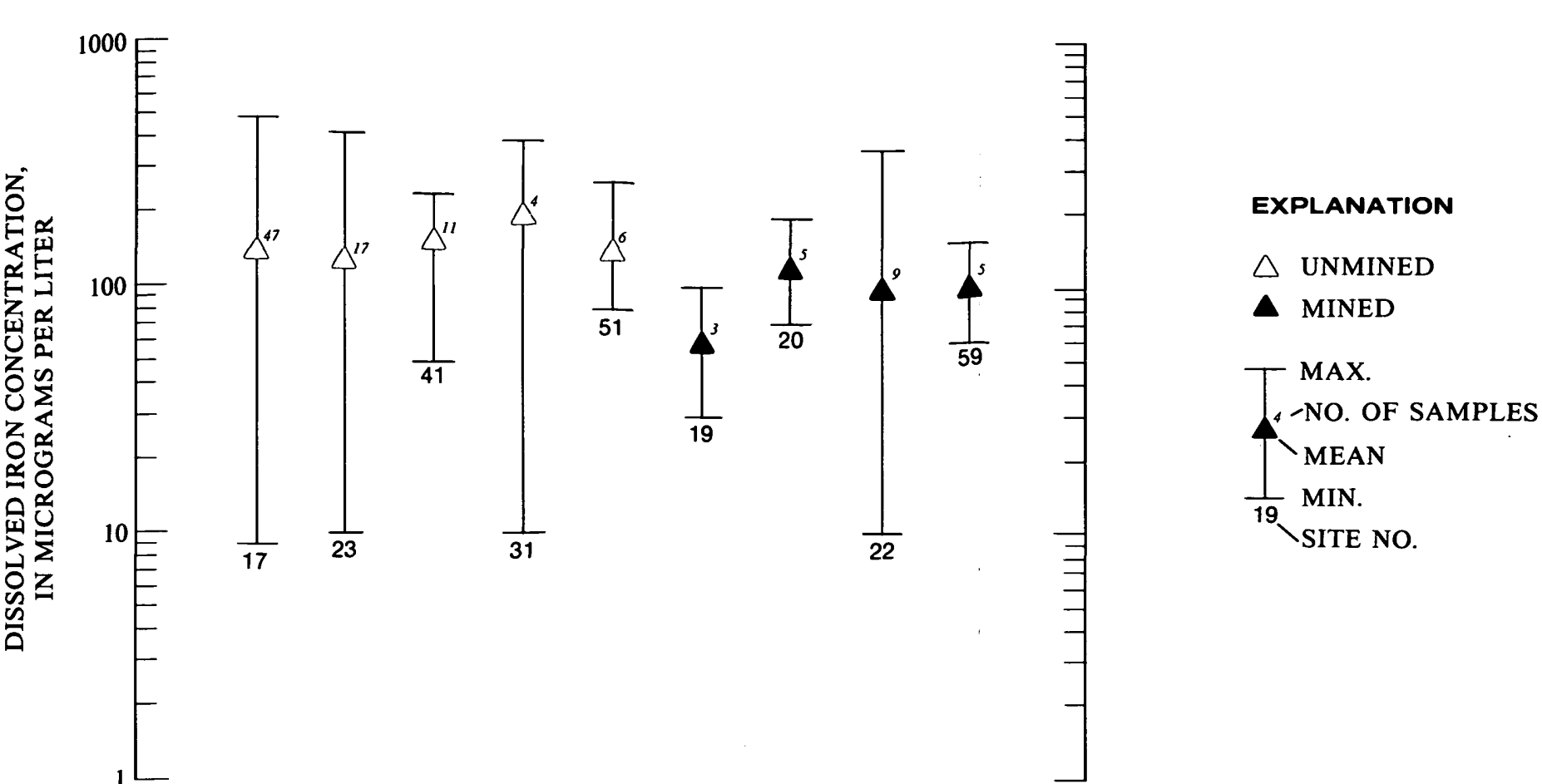

Figure 6.4-2 Mean and range of dissolved-iron concentrations

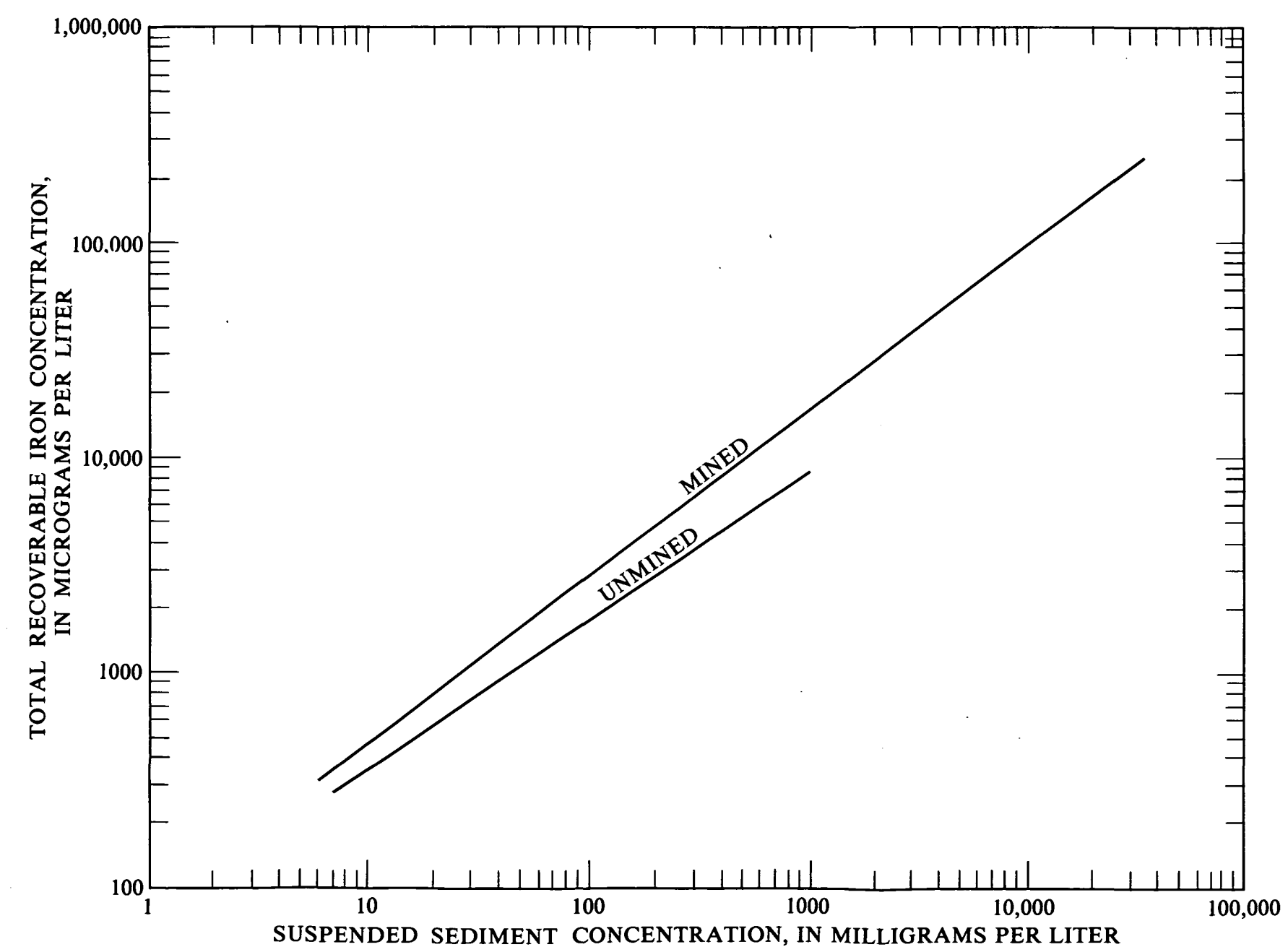

Figure 6.4-3 Relationship between total recoverable iron 


\title{
6.0 QUALITY OF SURFACE WATER (Continued) \\ 6.5 MANGANESE
}

\section{Manganese Concentrations are High in Streams Draining Mined Areas}

\author{
Dissolved-manganese concentrations from unmined basins range from \\ less than 2 to $200 \mu \mathrm{g} / \mathrm{L}$, while from mined basins range from 30 to \\ $1000 \mu \mathrm{g} / \mathrm{L}$. Total recoverable manganese ranges from about 25 to \\ $200 \mu \mathrm{g} / \mathrm{L}$ in unmined basins and from 150 to $6000 \mu \mathrm{g} / \mathrm{L}$ in \\ mined basins.
}

\begin{abstract}
Dissolved-manganese concentrations exceeding 50 $\mu \mathrm{g} / \mathrm{L}$ impart an objectional taste to water, cause staining, and limit the water's use for many domestic and industrial purposes. Manganese normally occurs in small quantities in water and generally is derived from soils rich in organic material and the geologic strata underlying the basins.
\end{abstract}

Dissolved concentrations in streams draining relatively undisturbed basins are generally less than $50 \mu \mathrm{g} / \mathrm{L}$ (figs. 6.5-1 and 6.5-2). In contrast, dissolved-manganese concentrations in streams draining mined areas are high and commonly exceed $100 \mu \mathrm{g} / \mathrm{L}$. Accelerated weathering of manganese minerals present in coal-mine spoils produces large quantities of soluble manganese salts that are contributed to streamflow draining mine areas. Dissolved concentration observed in mine drainage ranged from less than 10 to $1,800 \mu \mathrm{g} / \mathrm{L}$.

High dissolved-manganese concentrations observed in streams draining mined areas vary widely and contrast sharply with concentrations observed in streams draining unmined areas (fig. 6.5-2). Although dissolvedmanganese concentrations are high in and near coal-mine areas, aeration and dilution by alkaline streams $(\mathrm{pH}$ greater than 7.0 units) rapidly decrease the high concentrations. Dissolved-manganese concentrations in acidic or near neutral (6.0 to $8.0 \mathrm{pH}$ units) streams draining mined areas generally remain higher than those in streams draining unmined areas.

Aeration of alkaline mine drainage usually increases the formation of insoluble manganese precipitates. Sorption of these precipitates on stream sediments results in total recoverable manganese (dissolved and suspended) ranging as high as $200 \mu \mathrm{g} / \mathrm{L}$ in unmined areas and $6,000 \mu \mathrm{g} / \mathrm{L}$ in mined areas. Relations between total recoverable-manganese concentrations and suspendedsediment concentrations in streams draining mined and unmined basins are shown in figure 6.5-3. These relations may be used for estimating manganese loads from mined and unmined basins in the area. High suspended-sediment concentrations generally occur during high streamflow and low concentrations during low flow. During low flow, total recoverable-manganese concentrations are nearly the same as dissolved concentrations. 


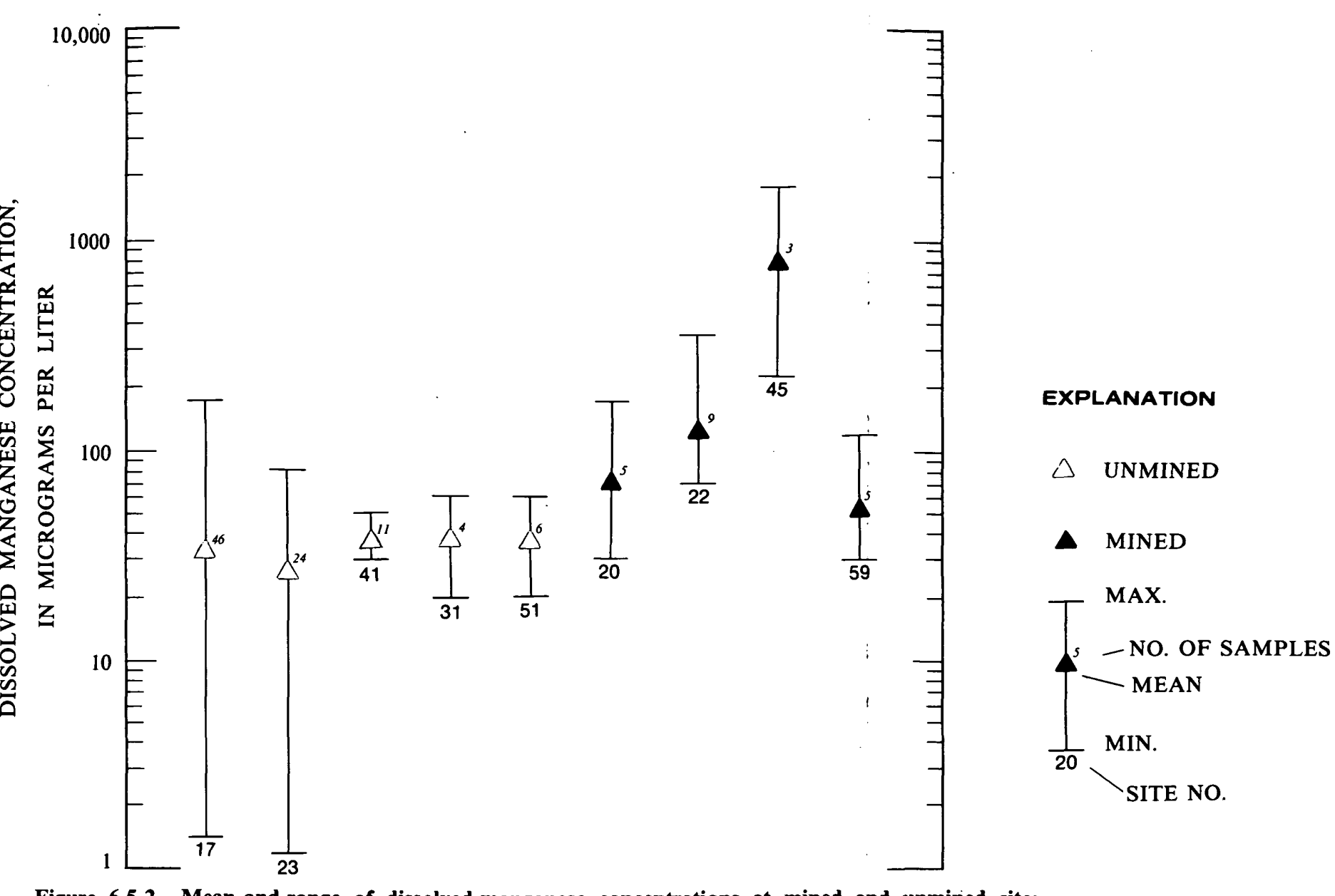

EXPLANATION

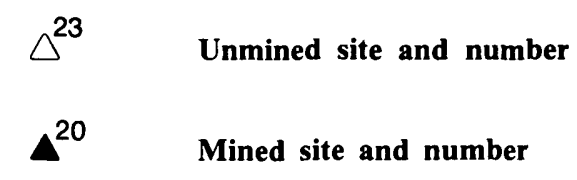

Figure 6.5-1 Location of selected sites for manganese concentrations.

Figure 6.5-2 Mean and range of dissolved-manganese concentrations at mined and unmined sites.

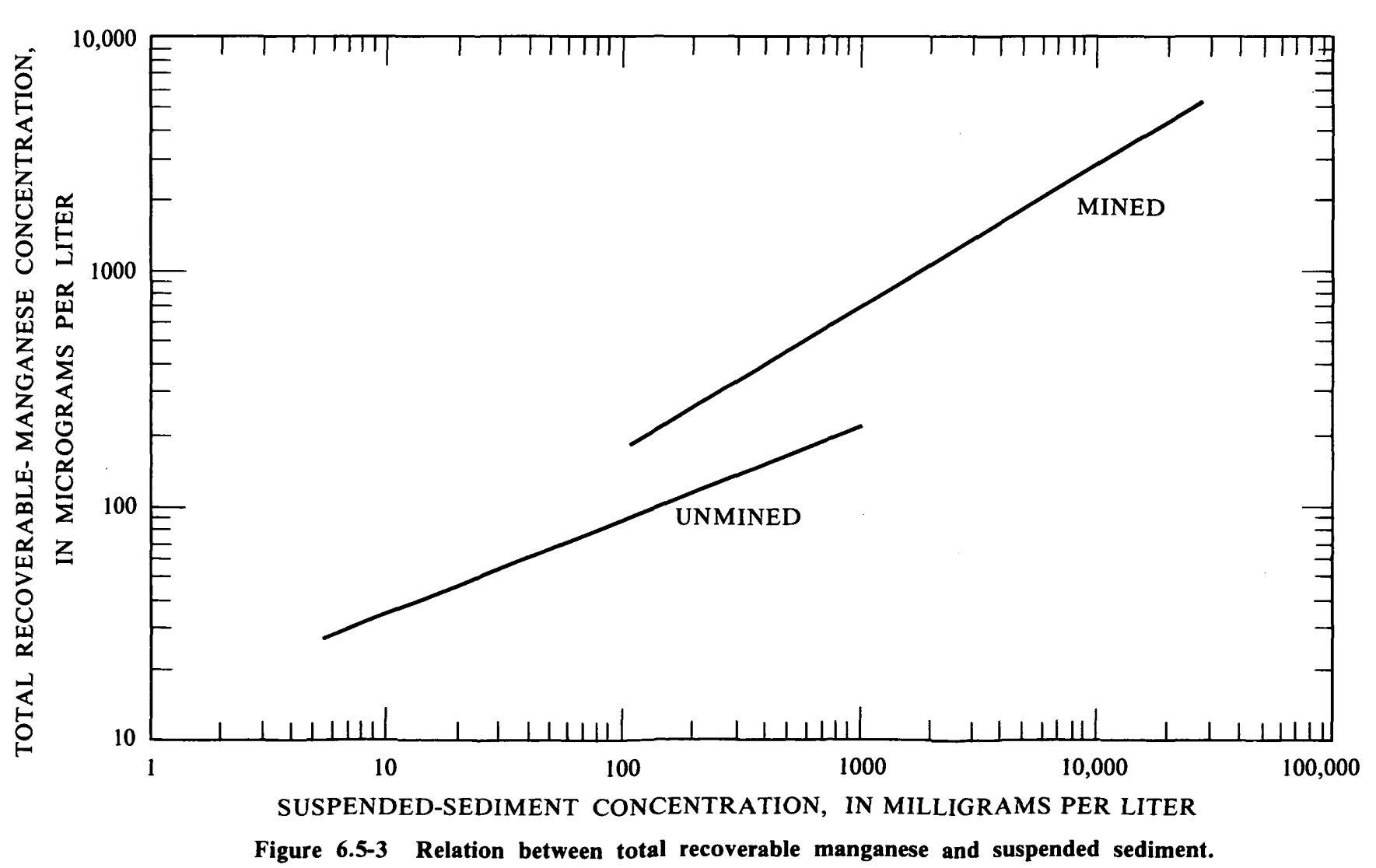

6.0 QUALITY OF SURFACE WATER (Continued) 6.5 MANGANESE 


\subsection{QUALITY OF SURFACE WATER (Continued) 6.6 SULFATE}

\section{Sulfate Concentrations Increase in Streams Draining Mined Areas}

\section{Sulfate concentrations in streams draining unmined areas generally ranged from / to $20 \mathrm{mg} / \mathrm{L}$ while those in streams draining mined areas ranged from 20 to $190 \mathrm{mg} / \mathrm{L}$.}

Sulfate concentrations in streams draining relatively undisturbed basins in Area 22 usually ranged from 1 to $20 \mathrm{mg} / \mathrm{L}$. In contrast, observed sulfate concentrations in streams draining mined areas were more variable and ranged from 20 to $190 \mathrm{mg} / \mathrm{L}$ (fig. 6.6-1). The relatively low range of sulfate concentrations in streams draining mined areas is due to dilution of the otherwise high concentrations in mine drainage. Sulfate concentrations in mine drainage may approach $2,000 \mathrm{mg} / \mathrm{L}$ as observed in adjacent Area 23, an area geologically similar to Area 22. Sulfate is usually the highest in concentration and the most persistent dissolved constituent in the water and is commonly used as an indicator of mine drainage.

Variability of sulfate concentrations in streams draining mined areas is primarily due to: (1) the presence of reactive minerals in spoil materials, (2) the length of time of exposure of these minerals to weath- ering, and (3) the quantity of water leaving the mined area. An example of the fluctuation of sulfate concentration in response to changes in streamflow at Dorsey Creek below Arkadelphia (site 22), draining a mined area, is shown in figure 6.6-2. In general, sulfate concentrations are highest during low flow, due to the presence of mine drainage and the lack of dilution by rainfall. In downstream areas sulfate concentrations usually decrease due to dilution.

Sulfate concentrations relate directly to specific conductance, which is an indicator of the degree of mineralization in water. This relation is illustrated in figure 6.6-3 and may be used to estimate the concentration of sulfate from known specific conductance in streams draining mined and unmined basins in the area. The relative positions of the lines in figure 6.6-3 indicate significant differences in sulfate concentration in water between streams draining mined and unmined areas. 
카างกร $9 \cdot 9$

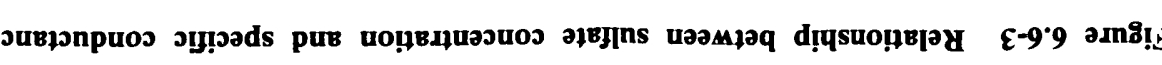

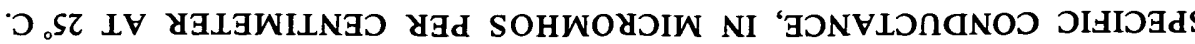

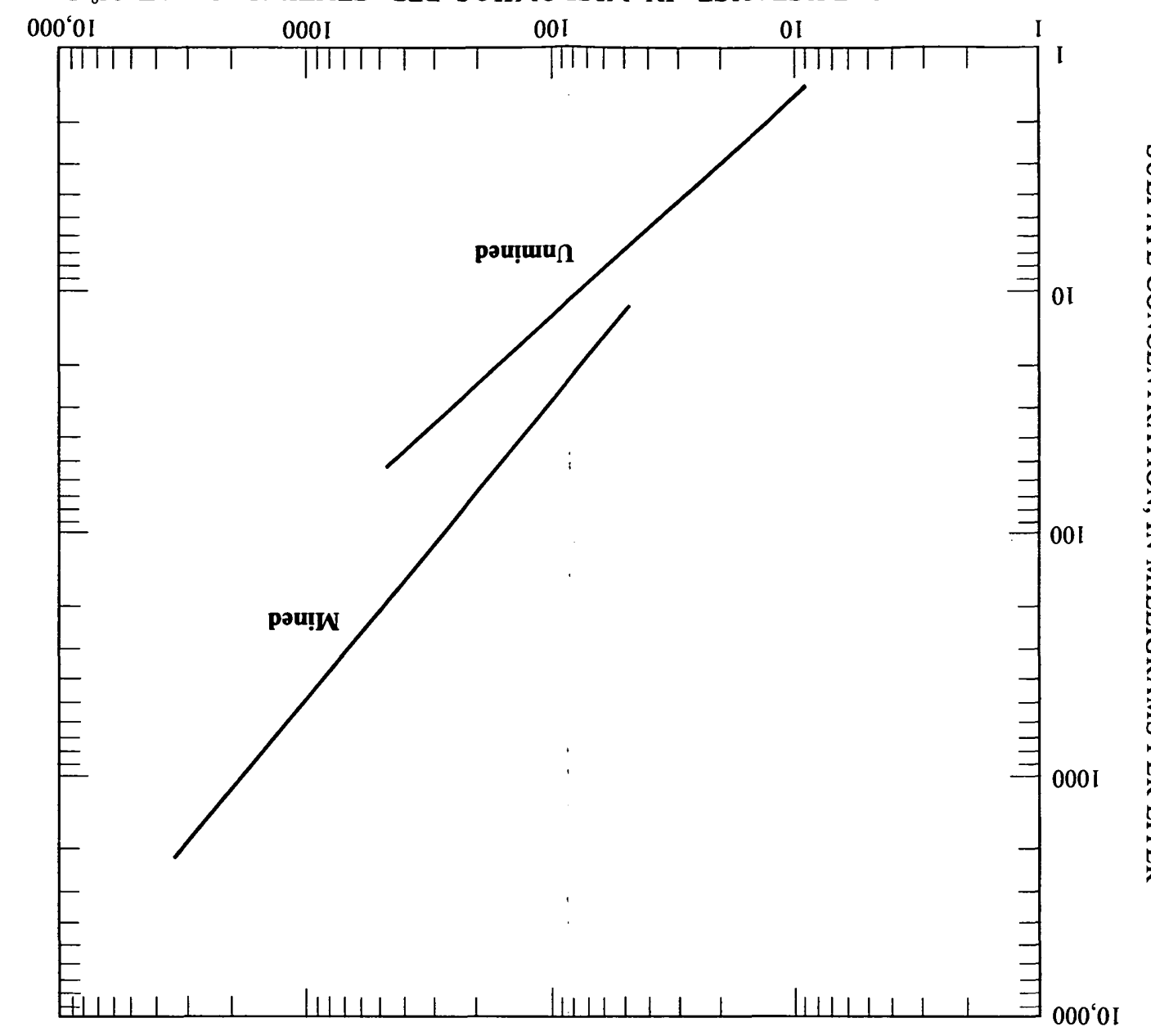

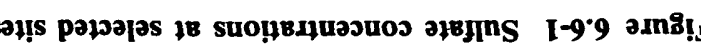

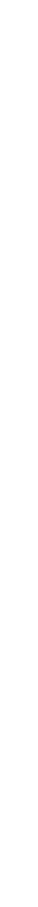

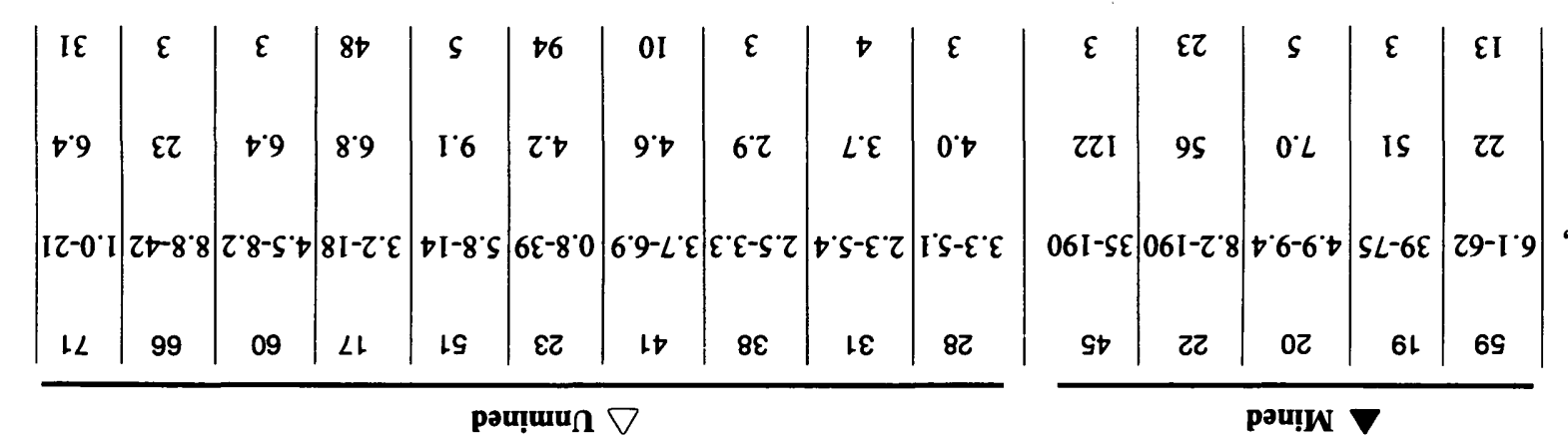

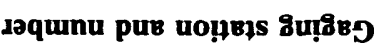

NOIL $\forall$ V7d $X \exists$

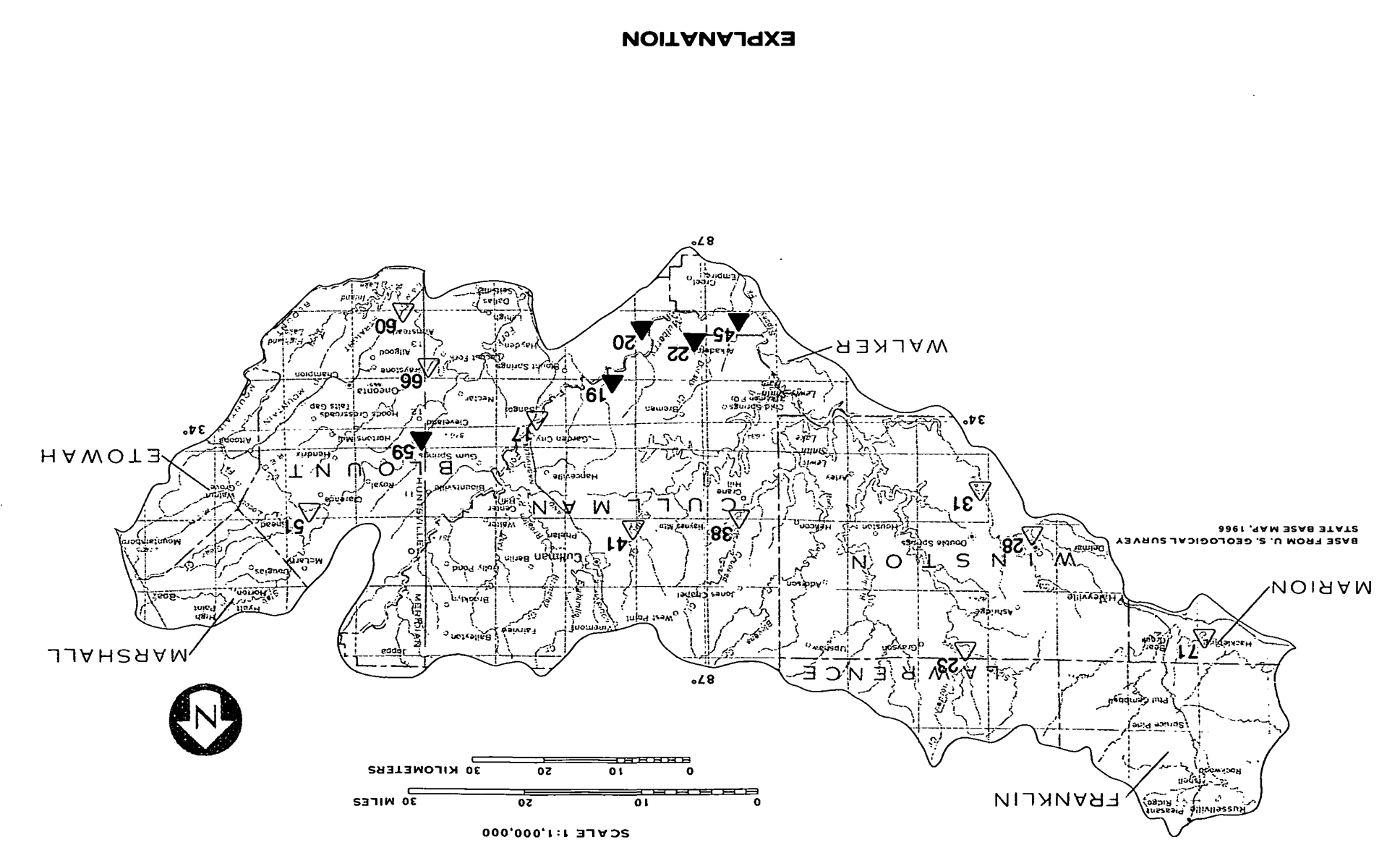

sэdures jo raquin $\mathbf{N}$

rəqunu uọ̣p!s

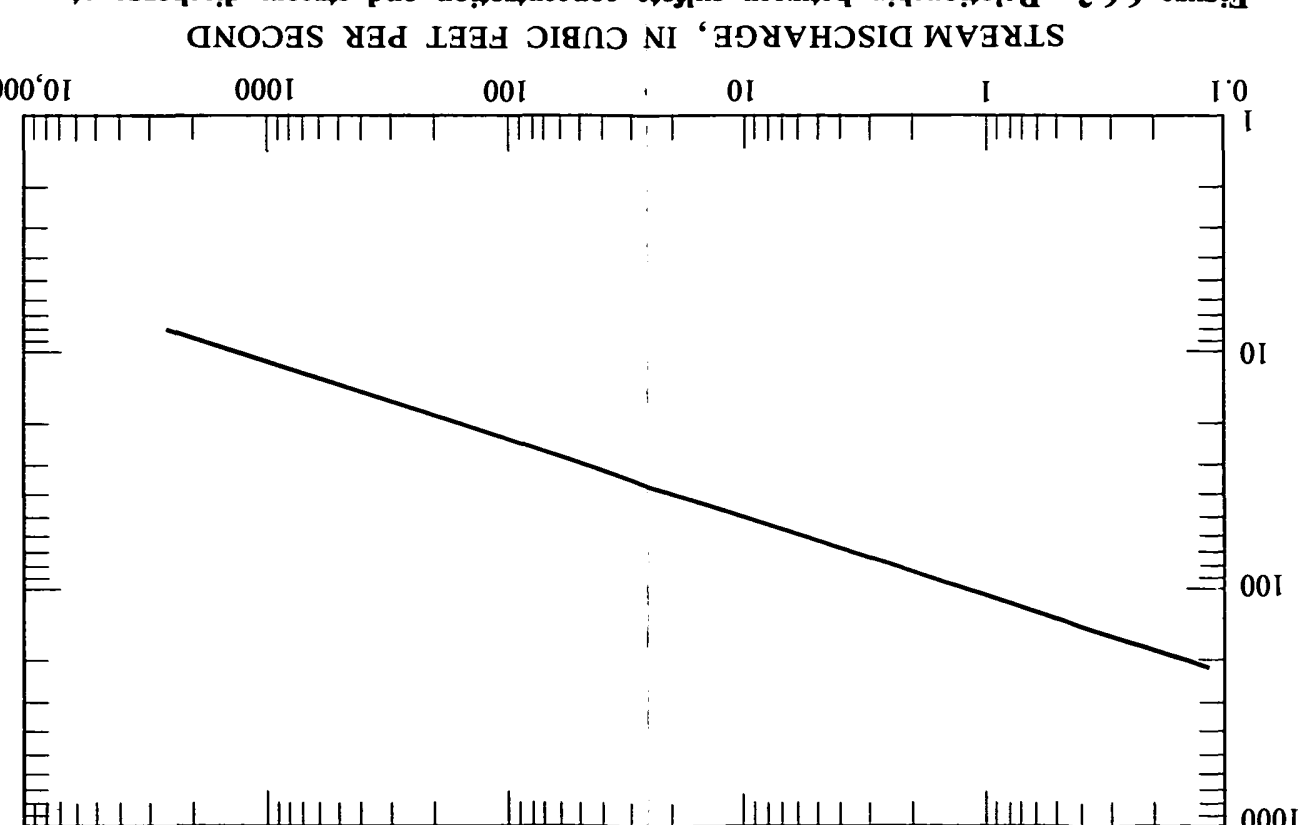




\subsection{QUALITY OF SURFACE WATER (Continued) \\ 6.7 TRACE ELEMENTS}

\section{Trace Elements Occur in Low Concentrations}

\section{Trace elements normally occur in low concentrations and generally are not a water-quality problem.}

Trace elements normally occur in small quantities in most streams. Major sources of these substances generally include soils, geologic strata underlying the basin and atmospheric fallout. In low concentrations trace elements are essential to life; in higher concentrations, some can be toxic to plants and animals. For example, selenium is considered an essential element for animals, but is toxic when ingested in concentrations as low as 700 micrograms per day. Maximum dissolved selenium concentrations in drinking water recommended by the U.S. Environmental Protection Agency (1977) is 10 $\mu \mathrm{g} / \mathrm{L}$. High concentrations in streams can occur naturally; however, most high concentrations generally are associated with municipal and industrial-waste discharges, or storm runoff from urban areas. In coal-mine areas accelerated weathering of pyritic minerals present in coal-mine spoils produces acidic mine drainage that is contributed to streamflow. The acid water reacts with other minerals and can produce adverse concentrations of trace elements in mine drainage.
In Area 22, however, concentrations of most dissolved trace elements observed in streams draining mined basins generally are low and comparable to streams draining unmined basins. Concentrations of selected elements at sites shown in figure 6.7-1 are summarized in table 6.7-1. The concentrations of all trace elements listed in the table are within maximum limits recommended by the U.S. Environmental Protection Agency (1977).

In general, dissolved trace elements that may occur in concentrations exceeding U.S. Environmental Protection Agency recommended limits (1977) in and near surface mines, usually decrease rapidly in nearby downstream reaches. The decrease generally results from chemical reactions and precipitation caused by near neutral $\mathrm{pH}$ (6.0-8.0 units) water in streams and the strong sorption attraction between trace elements and suspended sediments. 


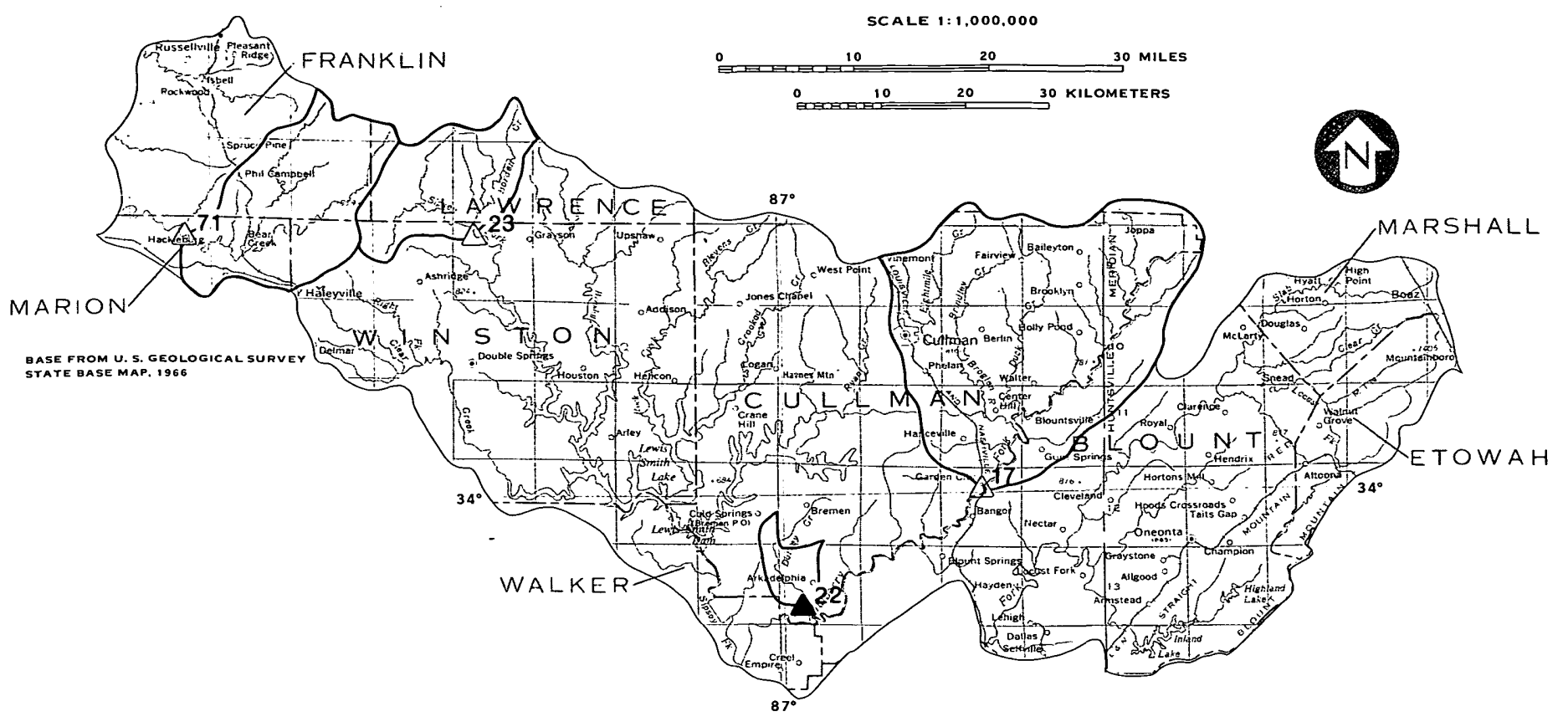

EXPLANATION

$\triangle^{22}$ Mined site and number

$\triangle^{23}$ Unmined site and number

Figure 6.7-1 Location of sampling sites for trace elements.
Table 6.7-1 Summary of selected trace element concentrations, at selected sites, in micrograms per liter.

\begin{tabular}{|c|c|c|c|c|c|c|c|c|c|c|c|c|c|c|c|c|}
\hline \multirow[t]{2}{*}{ Element } & \multicolumn{4}{|c|}{$\begin{array}{c}\text { Mulberry Fork } \\
\text { near Garden City } \\
\triangle \text { site } 17\end{array}$} & \multicolumn{4}{|c|}{$\begin{array}{l}\text { Dorsey Creek } \\
\text { below Arkadelphia } \\
\text { site } 22^{\text {site }}\end{array}$} & \multicolumn{4}{|c|}{$\begin{array}{c}\text { Sipsey Fork } \\
\text { near Grayson } \\
\triangle \text { site } 23\end{array}$} & \multicolumn{4}{|c|}{$\begin{array}{c}\text { Bear Creek } \\
\text { near Hackleberry } \\
\triangle \text { site } 71\end{array}$} \\
\hline & $\mathrm{N}$ & $\overline{\mathrm{X}}^{2}$ & MIN. & $\overline{\text { MAX }}$ & $\overline{N^{1}}$ & $\overline{\mathrm{x}}^{2}$ & MIN & MAX & $\overline{N^{1}}$ & $\overline{\bar{x}^{2}}$ & MIN & $\overline{\operatorname{MAX}}$ & $\overline{\mathbf{N}^{1}}$ & $\overline{\mathrm{X}}^{2}$ & MIN & MAX \\
\hline ALUMINUM & - & - & - & - & 9 & 70 & 10 & 400 & - & - & - & - & - & - & - & - \\
\hline ARSENIC & 41 & 1 & 0 & 3 & 2 & 0 & 0 & 0 & 5 & 2 & 0 & 10 & 27 & $<1$ & 0 & 3 \\
\hline CADMIUM & 41 & $<1$ & 0 & 1 & 2 & 2 & 0 & 4 & 6 & 1 & 0 & 5 & 27 & $<1$ & 0 & 1 \\
\hline CHROMIUM & 41 & $<1$ & 0 & 3 & 2 & 10 & 10 & 10 & 5 & 1 & 0 & 2 & 27 & $<1$ & 0 & 1 \\
\hline COBALT & 39 & 1 & 0 & 2 & 2 & $<1$ & 0 & 1 & 6 & 2 & 1 & 3 & 20 & $<1$ & 0 & 2 \\
\hline COPPER & 27 & 2 & 1 & 7 & 2 & 2 & 1 & 4 & 4 & 5 & 0 & 10 & 7 & 2 & 1 & 4 \\
\hline LEAD & 41 & 1 & 0 & 6 & 2 & 0 & 0 & 0 & 6 & 3 & 0 & 10 & 27 & 2 & 0 & 6 \\
\hline MERCURY & 41 & .3 & 0 & 1.8 & 2 & .3 & .1 & .5 & 5 & .2 & .1 & .5 . & 25 & .3 & 0 & .8 \\
\hline SELENIUM & 2 & 0 & 0 & 0 & 2 & 0 & 0 & 0 & 2 & 0 & 0 & 0 & 5 & 0 & 0 & 0 \\
\hline ZINC & 41 & 20 & 0 & 300 & 2 & 10 & 10 & 10 & 5 & 10 & 8 & 20 & 27 & 30 & 5 & 150 \\
\hline
\end{tabular}




\title{
7.0 GROUND WATER \\ 7.1 SOURCE, RECHARGE, AND MOVEMENT
}

\section{Three Aquifer Systems Underlie Area 22}

\author{
The Tuscaloosa Group, Pottsville Formation, and pre-Pennsylvanian \\ rocks outcrop and receive direct recharge in Area 22. The \\ movement of water in these aquifers is generally \\ to the southwest.
}

Ground water in Area 22 is derived from precipitation. Part of the precipitation returns to the atmosphere through evaporation and transpiration, part flows into streams and lakes as runoff, and part seeps downward through the soils and rocks to the zone of saturation.

Direct infiltration of precipitation into the aquifers is the major means of recharge, although some aquifers receive recharge indirectly by leakage from adjacent aquifers. Recharge also may result from streams flowing over the outcrops of aquifers. Where the water level in an aquifer is below that of the stream, water may percolate through the stream channel and into the aquifer.

Almost all ground water is in motion from areas of recharge to areas of discharge. The rate of movement in most aquifers is slow and depends on the size and degree of interconnection of the water-bearing openings and the hydraulic gradient. Rocks that transmit water readily are said to have high permeability or to be permeable. Among the more permeable rock units are well sorted sand and gravel, limestone with interconnected solution openings, and rocks with interconnected fracture systems. Among the least permeable units are clay, shale, and dense, consolidated rocks with no interconnecting fractures or solution openings.

Ground-water movement in Area 22 generally is to the southwest following the regional dip of the rock units. Locally, water flows toward points of discharge such as streams or wells. The path which water must take as it flows varies with the three different rock units in Area 22 (fig. 7.1-1).

Water flows freely through the sand and gravel beds of the Tuscaloosa Group, but the Tuscaloosa Group is not a major aquifer in Area 22 because of its limited thickness. Ground water in the pre-Pennsylvanian carbonate (limestone and dolomite) rocks occurs in solution openings developed along fractures and bedding planes. The interconnected solution openings in these rocks form a system of conduits that permits relatively free movement of large quantities of ground water. Beds of sandstone and conglomerate of the Pottsville Formation allow water movement but in smaller quantities because the water-bearing openings have not been enlarged by solution. Direction of water movement in the Pottsville Formation and in the pre-Pennsylvanian rocks is controlled locally by orientation of the fractures or solution openings. 


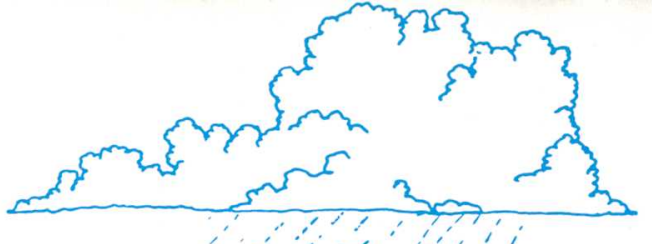

\section{TUSCALOOSA GROUP}
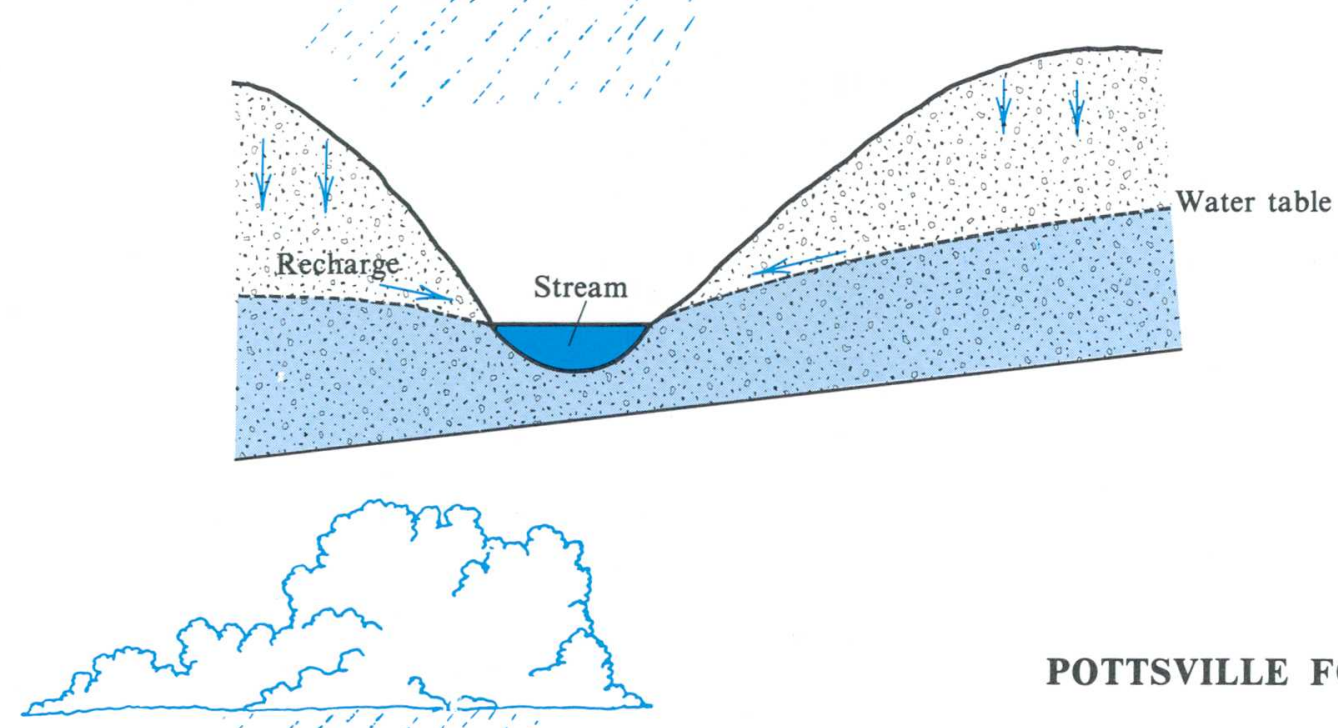

POTTSVILLE FORMATION
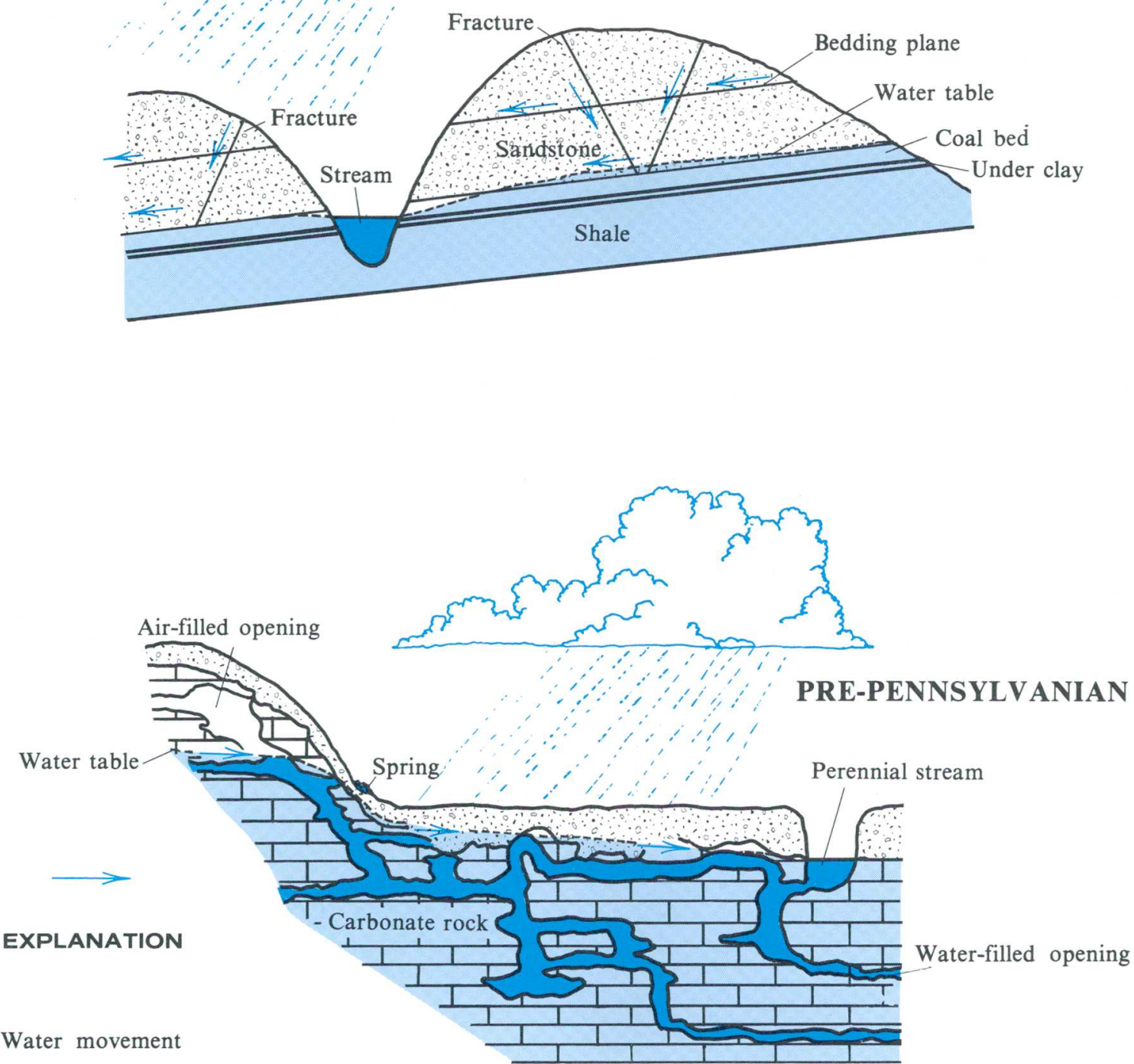

Figure 7.1-1 Water movement in aquifers. 


\title{
7.0 GROUND WATER (Continued) \\ 7.2 WATER LEVELS
}

\section{Ground-Water Levels in Area 22 Fluctuate Seasonally}

\author{
Water-level fluctuations reflect seasonal variations \\ in the rate of recharge to and discharge from the \\ ground-water reservoirs.
}

Seasonal variations in recharge produce fluctuations of water levels. Highest water levels occur in the spring prior to the onset of the growing season in response to recharge from precipitation. Lowest levels occur in the fall prior to the first killing frost when losses to evapotranspiration are reduced.

An observation well located at Cullman near the center of Area 22 taps the Pottsville Formation which underlies more than 85 percent of the area (fig. 7.2-1).
Water levels in the well were recorded continuously from March 1952 until April 1978 (fig. 7.2-2). Seasonal fluctuation was most extreme prior to 1956 , the year in which pumping in the area was discontinued. The seasonal pumping increased the normal fluctuation caused by precipitation and evapotranspiration. After 1956, a general rise in water level took place as the aquifer recovered from the effects of pumping. The recovery was most rapid during 1957 and 1958, and was not complete until about 1963. 


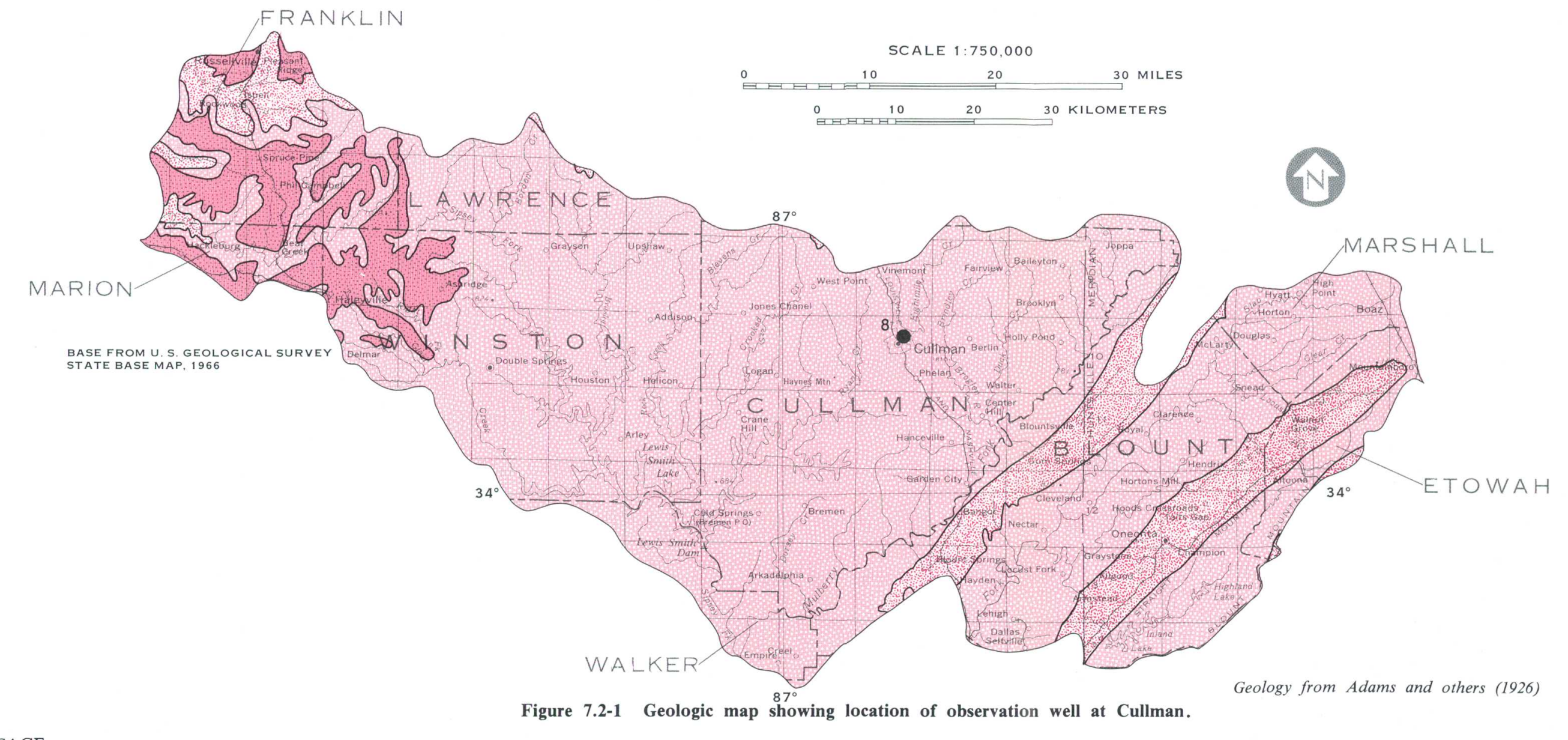

EXPLANATION

Tuscaloosa Group

Pottsville Formation

Pre-Pennsylvanian rocks

${ }^{8} \quad$ Observation well and number

Figure 7.2-1 Geologic map showing location of observation well at Cullman.

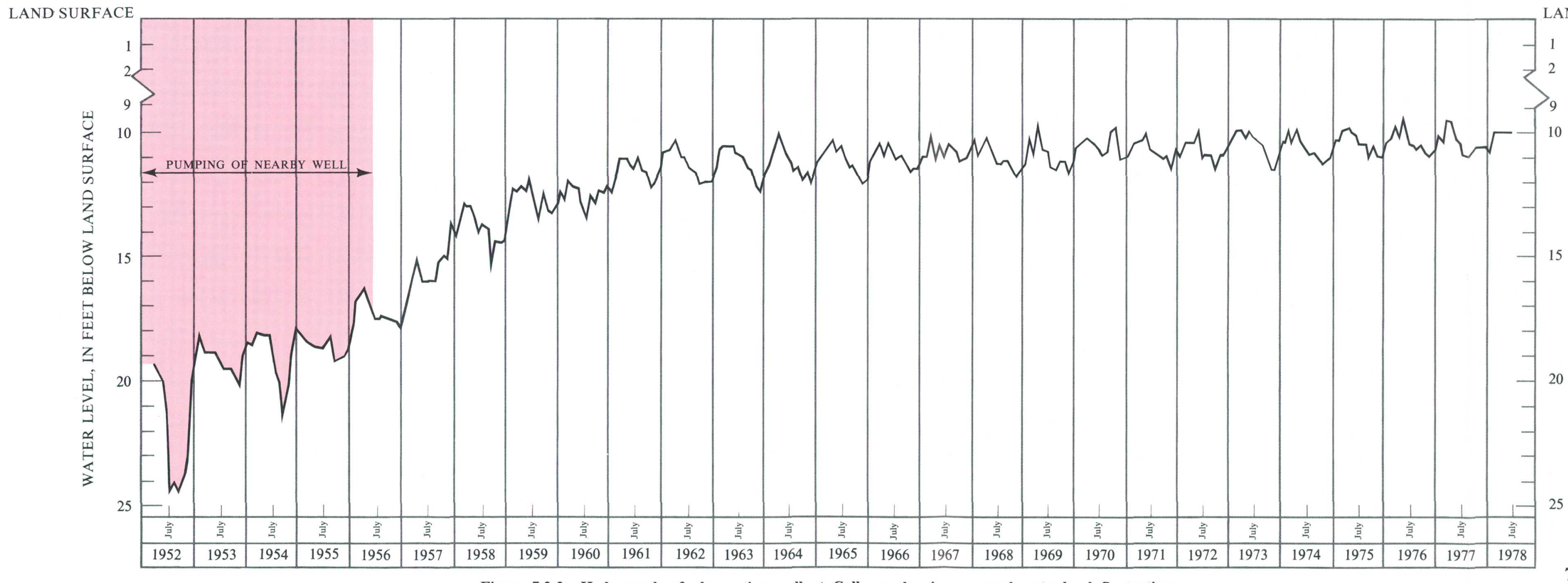

Figure 7.2-2 Hydrograph of observation well at Cullman showing seasonal water-level fluctuations. 


\title{
7.0 GROUND WATER (Continued) 7.3 WATER AVAILABILITY
}

\section{Three Major Rock Units Underlying Area 22 Have Diverse Water-Bearing Characteristics}

\author{
Expected well yields in the three major rock units in Area 22 \\ range from less than 5 to 1000 gallons per minute.
}

The principal source of ground-water supplies in most of Area 22 is the Pottsville Formation, which consists of alternating beds of sandstone and shale (fig. 7.3-1). Ground water in the Pottsville occurs in coal beds, in fractures and bedding planes, and in pore spaces in sandstone. Openings generally are small, and yields to wells range from less than $5 \mathrm{gal} / \mathrm{min}$ to as much as 50 $\mathrm{gal} / \mathrm{min}$. Depth to water generally is less than 30 feet in stream valleys and terraces and more than 50 feet on hills and ridges.

The availability of ground water in the prePennsylvanian rocks is related to topography, depth and extent of weathering and fracturing, existence of solution cavities, and rock type. The important aquifers are the carbonate rocks, such as limestone and dolomite, containing interconnected, solutionally enlarged openings. The limestone underlying Moulton Valley in the western part of Area 22 is dense and contains few fractures. Most wells in this valley yield less than 10 $\mathrm{gal} / \mathrm{min}$. In Murphrees and Sequatchie Valleys in the eastern part of Area 22, most of the pre-Pennsylvanian limestones and dolomites contain an abundance of chert which remains as the rock weathers forming a rubble zone above the bedrock. This rubble zone absorbs and stores large quantities of water to recharge the underlying limestone. Generally, the limestones in this eastern area are more fractured than those in the west. Wells constructed in valleys where the chert rubble zone is thickest may yield as much as $1000 \mathrm{gal} / \mathrm{min}$ (Faust and Harkins, 1980). Springs issuing from the limestone have measured flows of up to $3,990 \mathrm{gal} / \mathrm{min}$.

The Tuscaloosa Group is not a major source of water where it is present in Area 22 because of its limited thickness. The basal sand and gravel beds which are excellent aquifers to the south and west of Area 22 are too thin or are not areally extensive enough to retain large quantities of water. Yields to wells tapping the Tuscaloosa Group in the Area are from 5 to 10 $\mathrm{gal} / \mathrm{min}$. 


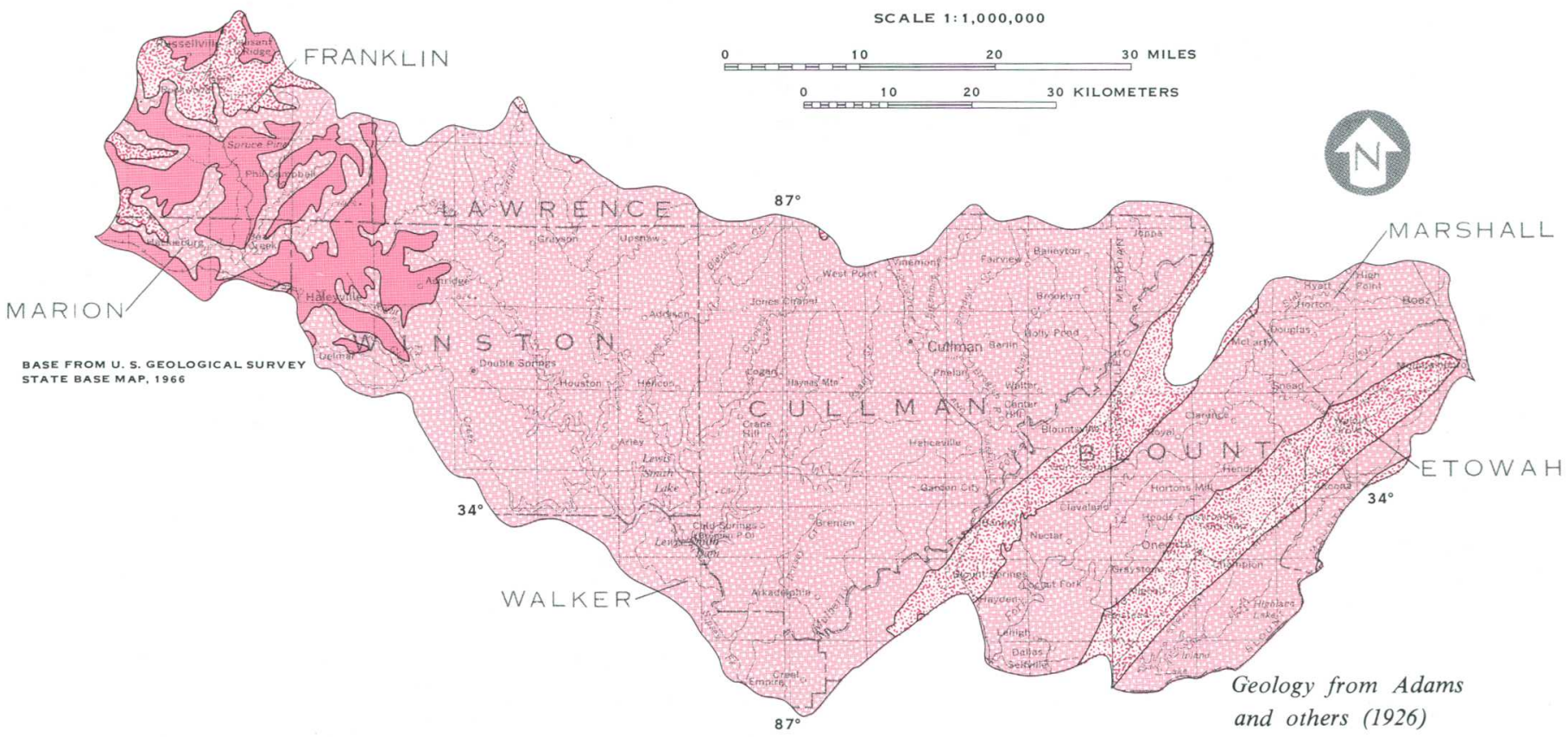

EXPLANATION

\section{YIELDS TO WELLS}

In gallons per minute

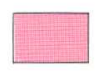

Tuscaloosa Group

From 5 to 10

\section{Pottsville Formation}

From less than 5 to 50

Pre-Pennsylvanian rocks

From less than 10 to 1,000

Figure 7.3-1 Availability of ground water. 


\subsection{QUALITY OF GROUND WATER}

\section{Chemical Quality of Ground Water is Variable, but Generally Good}

\section{Ground water is suitable for most domestic uses, except in local areas.}

Quality of ground water in Area 22 is highly variable, but is generally good and suitable for most uses. Average chemical quality by aquifer systems is shown in figure 8.0-1. Total ion concentrations (milliequivalents per liter) of water from wells in each unit are shown in the pie diagrams. Generally, the most undesirable constituent is iron, which in some localities exceeds the $0.3 \mathrm{mg} / \mathrm{L}$ (milligrams per liter) recommended limit for drinking water (U.S. Environmental Protection Agency, 1977).

Ground water in the Tuscaloosa Group has the lowest median $\mathrm{pH}$ (6.8 units) and the lowest average specific conductance (39 micromho/cm). The low specific conductance of water from the Tuscaloosa Group reflects the relative insolubility of the rocks. Ground water in the Pottsville Formation has a median $\mathrm{pH}$ value of 7.1 units, with an average specific conductance of 209 micromhos $/ \mathrm{cm}$. Ground water in prePennsylvanian rocks has a median $\mathrm{pH}$ of 7.4 units and an average specific conductance of $250 \mathrm{micromhos} / \mathrm{cm}$. Generally, water in the Pottsville Formation and prePennsylvanian rocks is more highly mineralized in the deeper wells. Soluble minerals in the Pottsville Formation and pre-Pennsylvanian rocks, with resulting increases in dissolved-solids concentration, generally does not present a water-quality problem.

The chemical character of ground water depends on several variables, such as composition of the aquifer, distance from recharge areas, residence time the water has been in contact with the rocks, and the overall pattern of ground-water circulation (Kaufman and Dion, 1967). A calcium-bicarbonate type of water is characteristic of pre-Pennsylvanian carbonate rocks (limestone and dolomite), and a calcium-magnesium-sodiumbicarbonate type of water is characteristic of the Pottsville Formation, which consists of shale, sandstone, and clay. Hardness $\left(\mathrm{CaCO}_{3}\right)$ of ground water in these geologic units varies from soft to very hard; dissolvedsolids concentrations are generally greater than 100 $\mathrm{mg} / \mathrm{L}$. A calcium-bicarbonate type water is characteristic of the Tuscaloosa Group, which consists chiefly of insoluble siliceous materials. Ground water in this formation is soft; dissolved-solids concentrations are generally less than $100 \mathrm{mg} / \mathrm{L}$. 

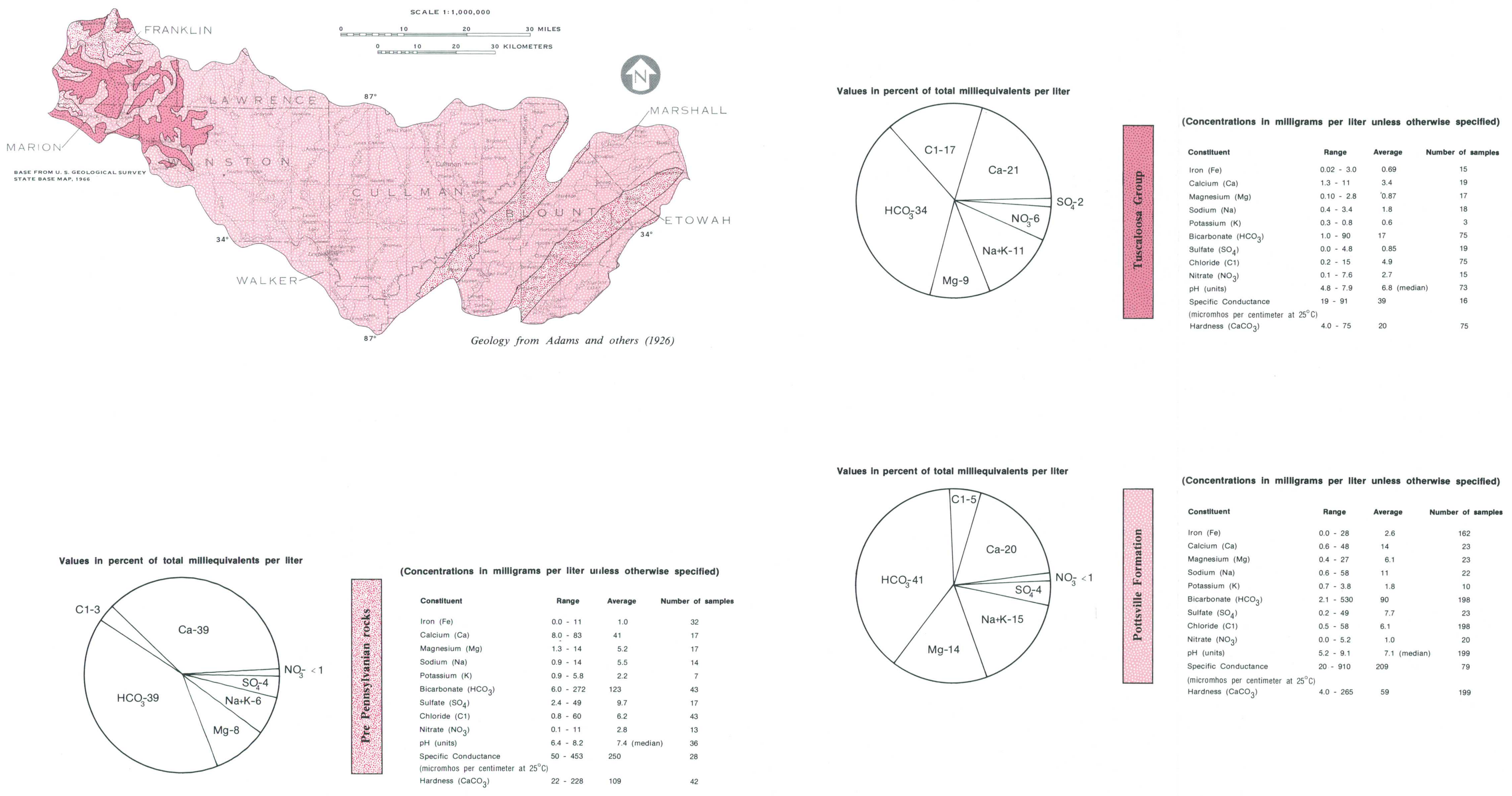

Figure 8.0-1 Chemical composition of ground water. 


\title{
NAWDEX, WATST $\emptyset$ RE, OWDC Have Water Data Information
}

\author{
Water data are collected in coal areas by large number of \\ organizations in response to a wide variety of missions and needs.
}

Within the U.S. Geological Survey there are three activities that help to identify and improve access to the vast amount of existing water data.

(1) The National Water Data Exchange(NAWDEX), which indexes the water data available from over 400 organizations and serves as a central focal point to help those in need of water data to determine what information already is available.

(2) The National Water Data Storage and Retrieval System (WATST $\emptyset \mathrm{RE}$ ), which serves as the central repository of water data collected by the U.S. Geological Survey and which contains large volumes of data on the quantity and quality of both surface and ground waters.

(3) The Office of Water Data Coordination (OWDC), which coordinates Federal water-data acquisition activities and maintains a "Catalog of Information on Water Data." To assist in identifying available water-data activities in coal provinces of the United States special indexes to the Catalog are being printed and made available to the public.

A more detailed explanation of these three activities are given in sections 9.2, 9.3, and 9.4. 


\section{NAWDEX Simplifies Access to Water Data}

\section{The National Water-Data Exchange (NAWDEX) is a nationwide program managed by the U.S. Geological Survey to assist users of water data or water-related data in identifying, locating, and acquiring needed data.}

NAWDEX is a national confederation of wateroriented organizations working together to make their data more readily accessible and to facilitate a more efficient exchange of water data.

Services are available through a Program Office located at the U.S. Geological Survey's National Center in Reston, Virginia, and a nationwide network of Assistance Centers located in 45 States and Puerto Rico, which provide local and convenient access to NAWDEX facilities (see fig. 9.2-1). A directory is available on request that provides names of organizations and persons to contact, addresses, telephone numbers, and office hours for each of these locations [ Directory of Assistance Centers of the National Water Data Exchange (NAWDEX), U.S. Geological Survey Open-File Report 79-423 (revised)].

NAWDEX can assist any organization or individual in identifying and locating needed water data and referring the requester to the organization that retains the data required. To accomplish this service, NAWDEX maintains a computerized Master Water Data Index (fig. 9.2-2), which identifies sites for which water data are available, the type of data available for each site, and the organization retaining the data. A Water Data Sources Directory (fig. 9.2-3) also is maintained that identifies organizations that are sources of water data and the locations within these organizations from which data may be obtained. In addition NAWDEX has direct access to some large water-data bases of its members and has reciprocal agreements for the exchange of services with others.

Charges for NAWDEX services are assessed at the option of the organization providing the requested data or data service. Search assistance services are provided free by NAWDEX to the greatest extent possible. Charges are assessed, however, for those requests requiring computer cost, extensive personnel time, duplicating services, or other costs encountered by NAWDEX in the course of providing services. In all cases, charges assessed by NAWDEX Assistance Centers will not exceed the direct costs incurred in responding to the data request. Estimates of cost are provided by NAWDEX upon request and in all cases where costs are anticipated to be substantial.

For additional information concerning the NAWDEX program or its services contact:

$$
\begin{gathered}
\text { Program Office } \\
\text { National Water Data Exchange (NAWDEX) } \\
\text { U.S. Geological Survey } \\
421 \text { National Center } \\
\text { 12201 Sunrise Valley Drive } \\
\text { Reston, VA 22092 } \\
\text { Telephone: (703) } 860-6031 \\
\text { FTS } 928-6031
\end{gathered}
$$

Hours: 7:45 - 4:15 Eastern Time

or

\section{NAWDEX ASSISTANCE CENTER}

\author{
ALABAMA \\ U.S. Geological Survey \\ Water Resources Division \\ Room 202, Oil \& Gas Board Bldg. \\ P. O. Box V \\ University, AL 35486 \\ Telephone: (205) 752-8104 \\ FTS 229-2957 \\ Hours: $7: 30$ to $4: 00$ Central Time
}




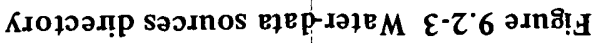

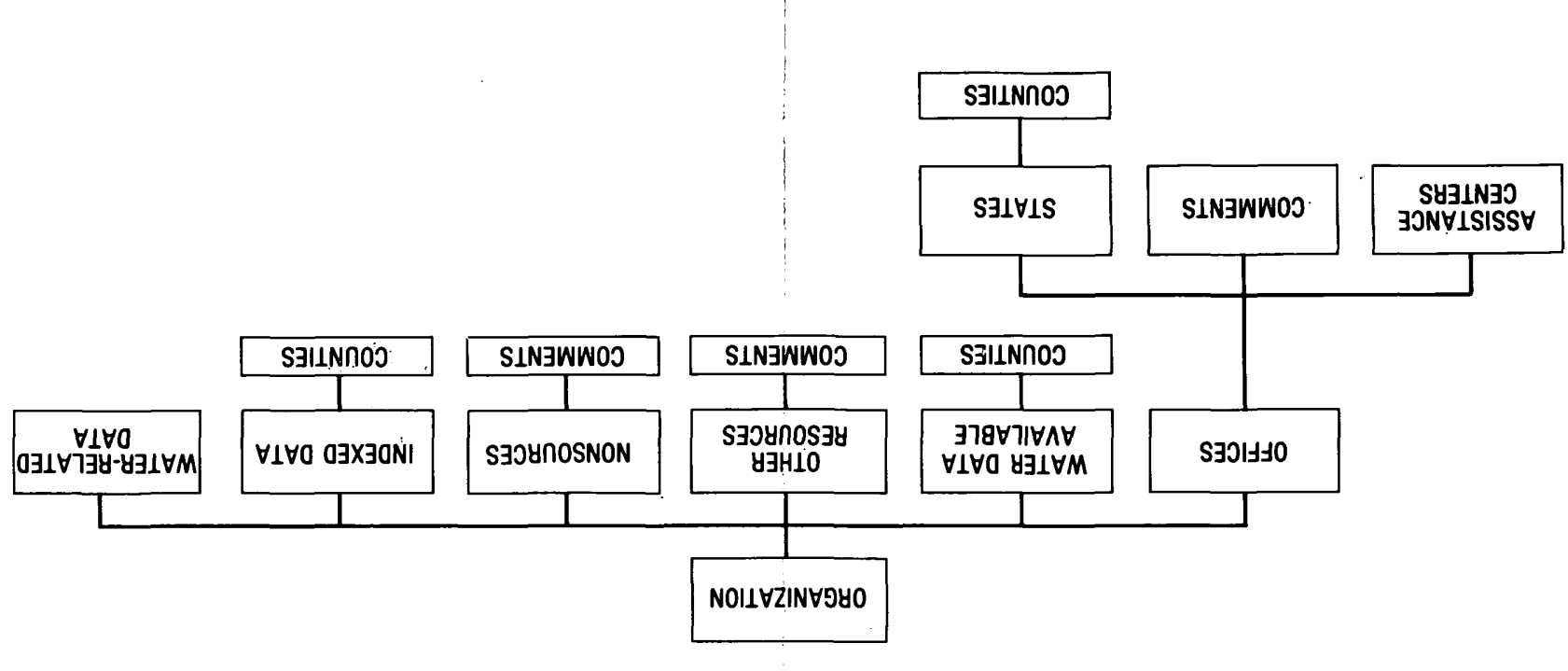

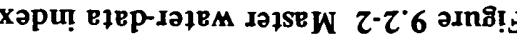

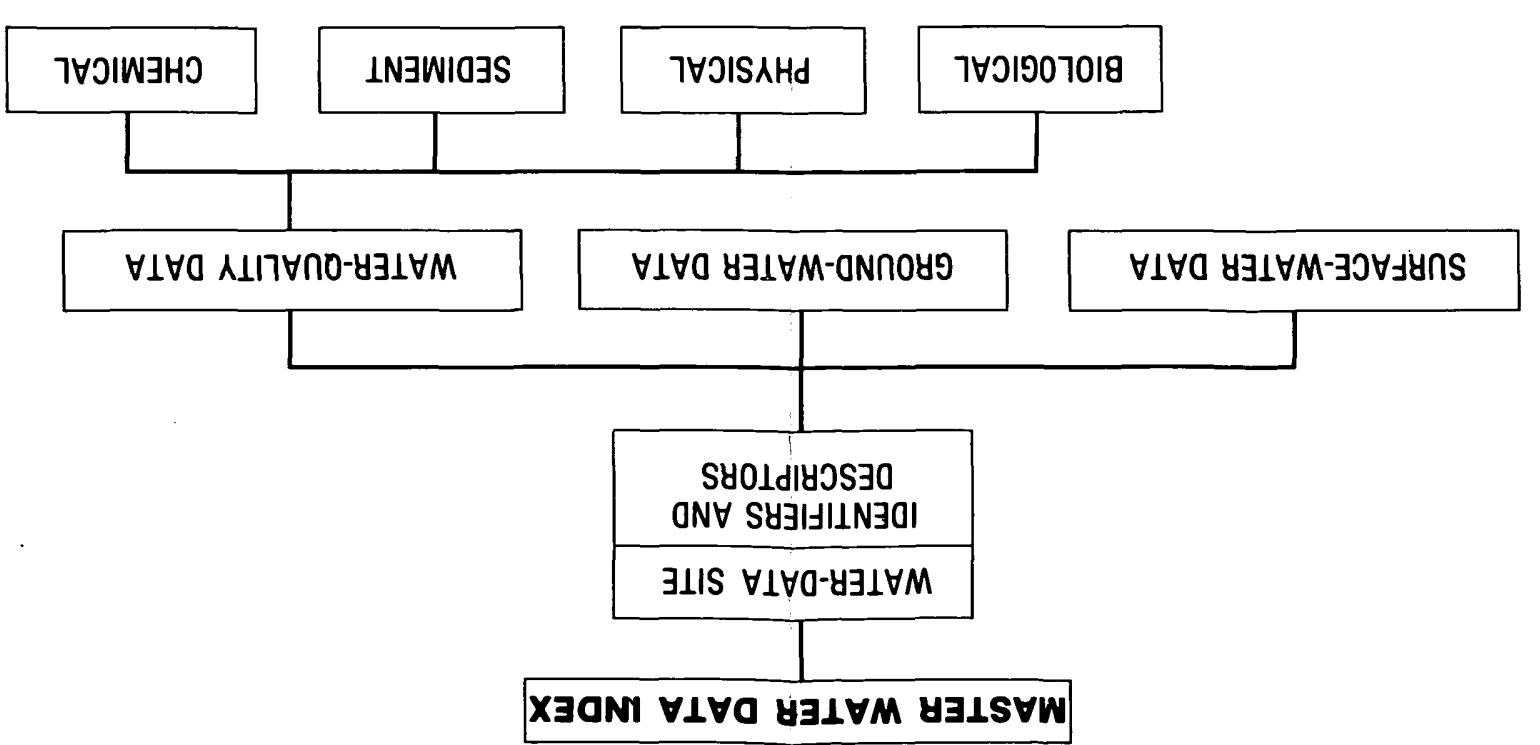

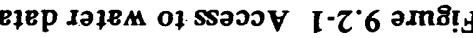

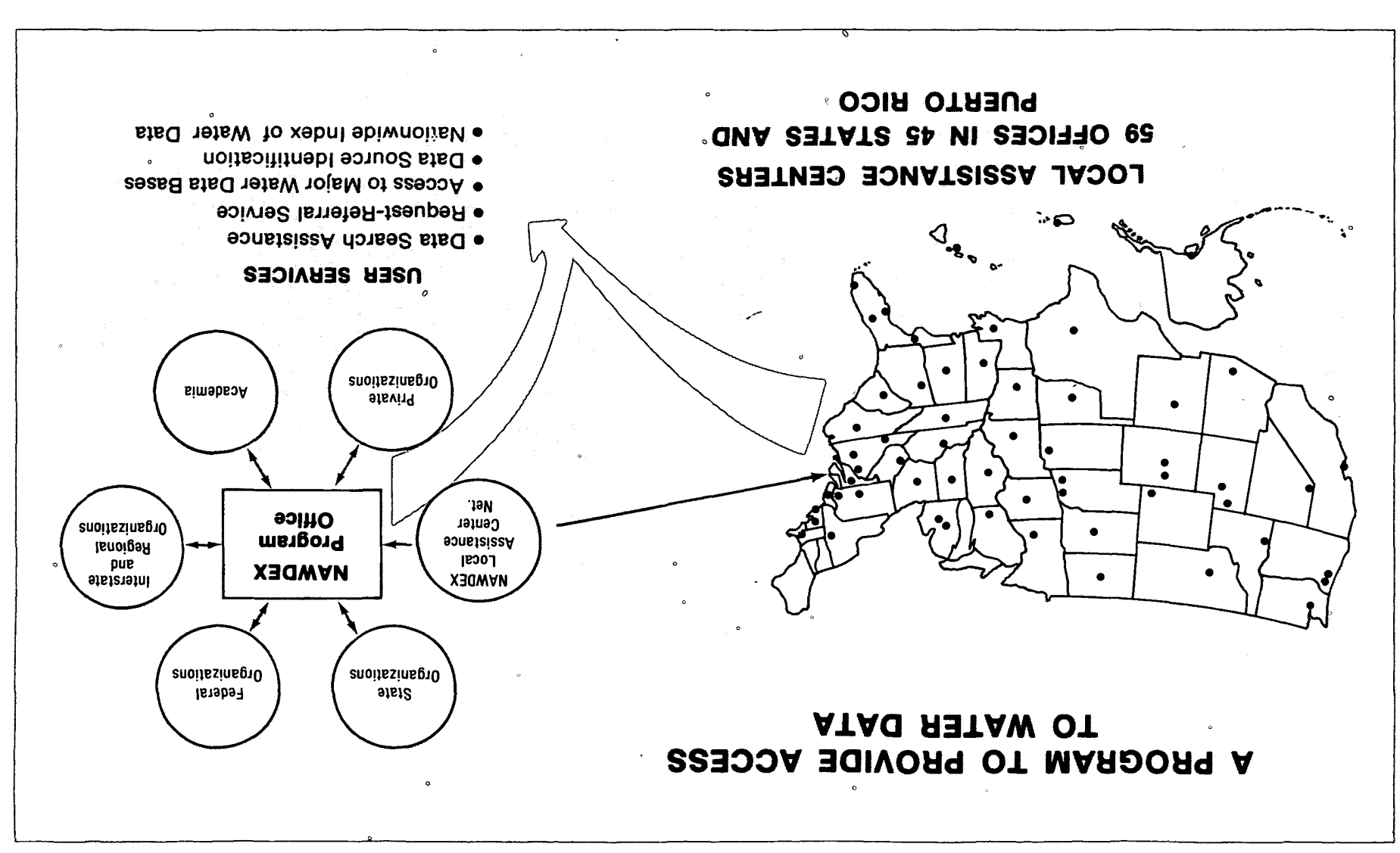




\title{
9.0 WATER-DATA SOURCES (Continued) 9.3 WATSTØRE
}

\section{WATST $\emptyset$ RE Automated Data System}

\author{
The National Water Data Storage and Retrieval System (WATSTØRE) of the \\ U.S. Geological Survey provides computerized procedures and techniques \\ for processing water data and provides effective and efficient \\ management of data-releasing activities.
}

The National Water Data Storage and Retrieval System (WATST $\varnothing \mathrm{RE}$ ) was established in November 1971 to computerize the U.S. Geological Survey's existing water-data system and to provide for more effective and efficient management of its data-releasing activities. The system is operated and maintained on the central computer facilities of the Survey at its National Center in Reston, Va. Data may be obtained from WATST $\emptyset \mathrm{RE}$ through the Water Resources Division's 46 district offices. General inquiries about WATST $\emptyset \mathrm{RE}$ may be directed to:

Chief Hydrologist

U. S. Geological Survey

437 National Center

Reston, VA 22092

or

\author{
U. S. Geological Survey \\ Water Resources Division \\ Room 202, Oil \& Gas Board Building \\ P. O. Box V \\ University, AL 35486
}

The Geological Survey currently (1980) collects data at approximately 16,000 streamgaging stations, 1,000 lakes and reservoirs, 5,200 surface-water quality stations, 1,020 sediment stations, 30,000 water-level observation wells, and 12,500 ground-water quality wells. Each year many water-data collection sites are added and others are discontinued; thus, large amounts of diversified data, both current and historical, are amassed by the Survey's data-collection activities.

The WATST $\emptyset$ RE system consists of several files in which data are grouped and stored by common characteristics and data-collection frequencies. The system also is designed to allow for the inclusion of additional data files as needed. Currently, files are maintained for the storage of: (1) surface-water, quality-of-water, and ground-water data measured on a daily or continuous basis; (2) annual peak values for streamflow stations; (3) chemical analyses for surface- and ground-water sites; (4) water parameters measured more frequently than daily; and (5) geologic and inventory data for ground-water sites. In addition, an index file of sites for which data are stored in the system is also maintained (fig. 9.3-1). A brief description of each file is as follows:

Station Header File: All sites for which data are stored in the Daily Values, Peak Flow, Water-Quality, and Unit Values files of WATST $\varnothing \mathrm{RE}$ are indexed in this file. It contains information pertinent to the identification, location, and physical description of nearly 220,000 sites.

Daily Values File: All water-data parameters measured or observed either on a daily or on a continuous basis and numerically reduced to daily values are stored in this file. Instantaneous measurements at fixed-time intervals, daily mean values, and statistics such as daily maximum and minimum values also may be stored. This file currently contains over 200 million daily values including data on streamflow, river stages, reservoir contents, water temperatures, specific-conductance, sediment concentrations, sediment discharges, and ground-water levels.

Peak Flow File: Annual maximum (peak) streamflow (discharge) and gage height (stage) values at surfacewater sites comprise this file, which currently contains over 400,000 peak observations.

Water-Quality File: Results of over 1.4 million analyses of water samples that describe the chemical, physical, biological, and radiochemical characteristics of both surface and ground waters are contained in this file. These analyses contain data for 185 different constituents.

Unit Values File: Water parameters measured on a schedule more frequent than daily are stored in this file. Rainfall, stream discharge, and temperature data are examples of the types of data stored in the Unit Values File. 
Ground-Water Site-Inventory File: This file is maintained within WATST $\varphi$ RE independent of the files discussed above, but it is cross-referenced to the WaterQuality Fle and the Dally Values Fle. It contains . identification geohydrologic characteristics, wellconstruction history, and one-time field measurements such as water temperature. The file is designed to accomodate 255 data elements and currently contains data for nearly 700,000 sites.

All data files of the WATST $\emptyset$ RE system are mainained and managed on the central computer facilities of data may be entered into or retrieved from WATST $\emptyset$ RE at a number of locations that are part of a nationwide telecommunication network.

Remote Job Entry Sites: Almost all of the Water Resources Division's district offices are equipped with hATSTORE to put data into or retrieve data from the system within several minutes to overnight, depending upon the priority placed on the request. The number of remote job entry sites is increased as the need arises.

Digital Transmission Sites: Digital recorders are used at many field locations to record values for parameters sunc as fiver stages, contion, and chlorides. Dat are recorded on 16-channel paper tape, which is removed from the recorder and transmitted over telephone lines to the receiver at Reston, Va. The data are recorded on magnetic tape for use on the central computer. Extensive testing of satellite data collection platforms indicates their feasibility for collecting real thme hydrologic data on a national scale. Battery-operated radios are 200 deta relay stations are being operated currently (1980).

Central Laboratory System: The Water Resources Division's two water-quality laboratories, located in Denver, Colo., and Atlanta, Ga., analyze more than 150,000 water samples per year. These laboratories are equipped to automatically perform chemical analyses ranging from determinations of simple inorganic compounds, such as pesticides. As each analysis is completed, the results are verified by laboratory personnel and transmitted via a computer terminal to the central computer facilities to be stored in the Water-Quality File of WATST $\emptyset$ RE.
Water data are used in many ways by decisionmakers for the management, development, and monitoring of our water resources. In addition to its dat WATSTQRE can provide a variety of useful products ranging from simple data tables to complex statistica analyses. A minimal fee, plus the actual computer cost incurred in producing a desired product, is charged to the requester.

Computer-Printed Tables: Users most often request data fromputer. These thes may contain lists of actul data or condensed indexes that indicate the availability of data stored in the files. A variety of formats is available to display the many types of data.

Computer-Printed Graphs: Computer-printed graph for the rapid analysis or display of data are another capabily to WATSTER. Conputer programs are frequency distribution curves, X-Y point plots, sitelocation map plots, and other similar items by means of line printers.

Statistical Analyses: WATST $Q$ RE interfaces with propietary statstical package (SAS) to provide extensive analyses of data such as regression analyses, the

Digital Plotting: WATSTORE also makes use of ftware systems that prepare data for digital plotting on peripheral offline plotters available at the central com puter site. Plots that can be obtained include hydrographs, frequency distribution curves, X-Y point plots, contour plots, and three-dimensional plots.

Data in Machine-Readable Form: Data stored in for use on other computers or for use as input to userwritten computer programs. These data are available in the standard storage format of the WATST or in the form of punched cards or card images on magnetic tape.
NATIONAL WATER DATA STORAGE AND RETRIEVAL SYSTEM STATION-HEADER FILE

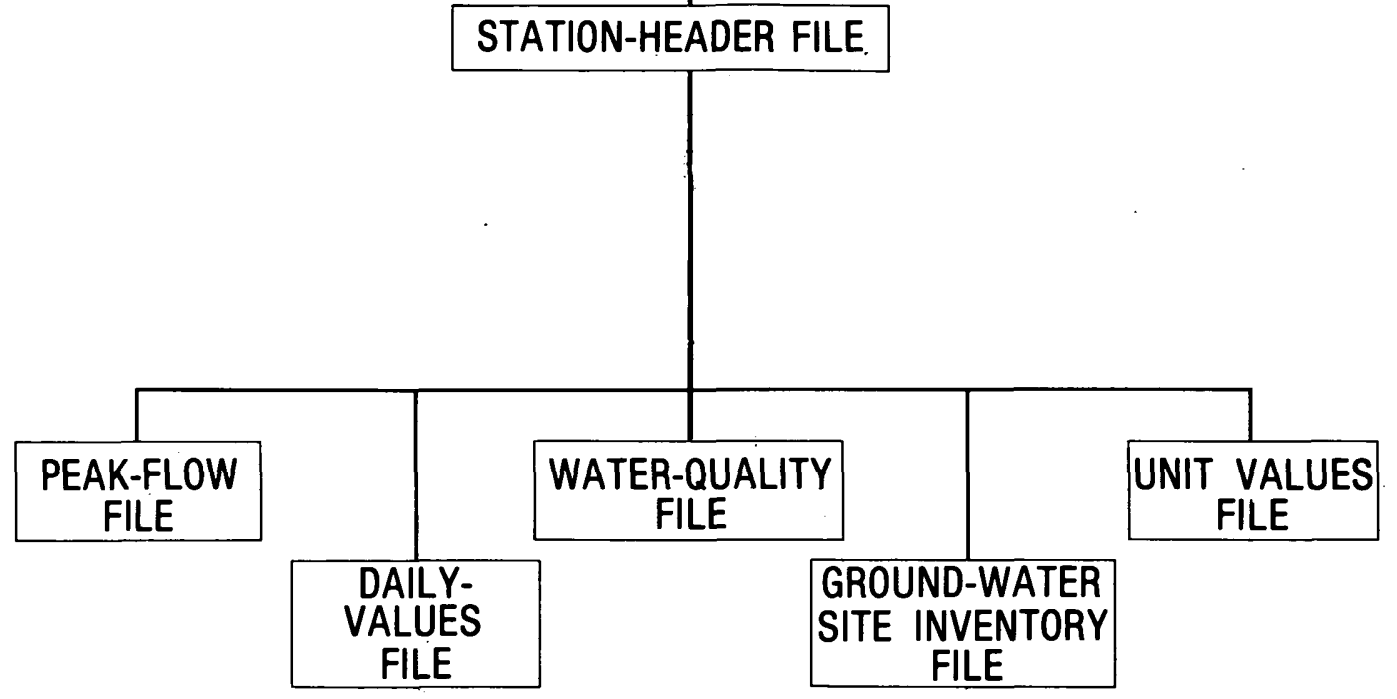

Figure 9.3-1 Index file.stored data 


\subsection{WATER-DATA SOURCES (Continued) 9.4 INDEX TO WATER-DATA ACTIVITIES IN COAL PROVINCES}

\section{Water Data Indexed for Coal Provinces}

\section{A special index, "Index to Water-Data Activities in Coal Provinces of the United States," has been published by the U.S. Geological Survey's Office of Water Data Coordination (OWDC).}

The "Index to Water-Data Activities in Coal Provinces of the United States" was prepared to assist those involved in developing, managing, and regulating the Nation's coal resources by providing information on the availability of water-resources data in the major coal provinces of the United States. It is derived from the "Catalog of Information on Water Data," which is a computerized information file about water-data acquisition activities in the United States, and its territories and possessions, with some international activities included.

This special index consists of five volumes (fig. 9.4-1): volume I, Eastern Coal province; volume II, Interior Coal province; volume III, Northern Great Plains and Rocky Mountain Coal provinces; volume IV, Gulf Coast Coal province; and volume V, Pacific Coast and Alaska Coal provinces. The information presented will aid the user in obtaining data for evaluating the effects of coal mining on water resources and in developing plans for meeting additional water-data needs. The report does not contain the actual data; rather, it provides information that will enable the user to determine if needed data are available.

Each volume of this special index consists of four parts: Part A, Streamflow and Stage Stations; Part B, Quality of Surface-Water Stations; Part C, Quality of Ground-Water Stations; and Part D, Areal Investigations and Miscellaneous Activities. Information given for each activity in Parts A-C includes: (1) the identification and location of the station, (2) the major types of data collected, (3) the frequency of data collection, (4) the form in which the data are stored, and (5) the agency or organization reporting the activity. Part D summarizes areal hydrologic investigations and water-data activities not included in the other parts of the index. The agencies that submitted the information, agency codes, and the number of activities reported by type are shown in a table.

Those who need additional information from the Catalog file or who need assistance in obtaining water data should contact the National Water Data Exchange (NAWDEX) (See section 9.2).

Further information on the index volumes and their availability may be obtained from:

\author{
U. S. Geological Survey \\ Water Resources Division \\ Room 202, Oil \& Gas Board Bldg. \\ P. O. Box V \\ University, AL 35486 \\ Telephone: (205) 752-8104 \\ FTS 229-2957 \\ or \\ Office of Surface Mining \\ U. S. Department of the Interior \\ 530 Gay St., Suite 500 \\ Knoxville, TN 37902 \\ Telephone: (615) 637-8060 \\ FTS 852-0060
}




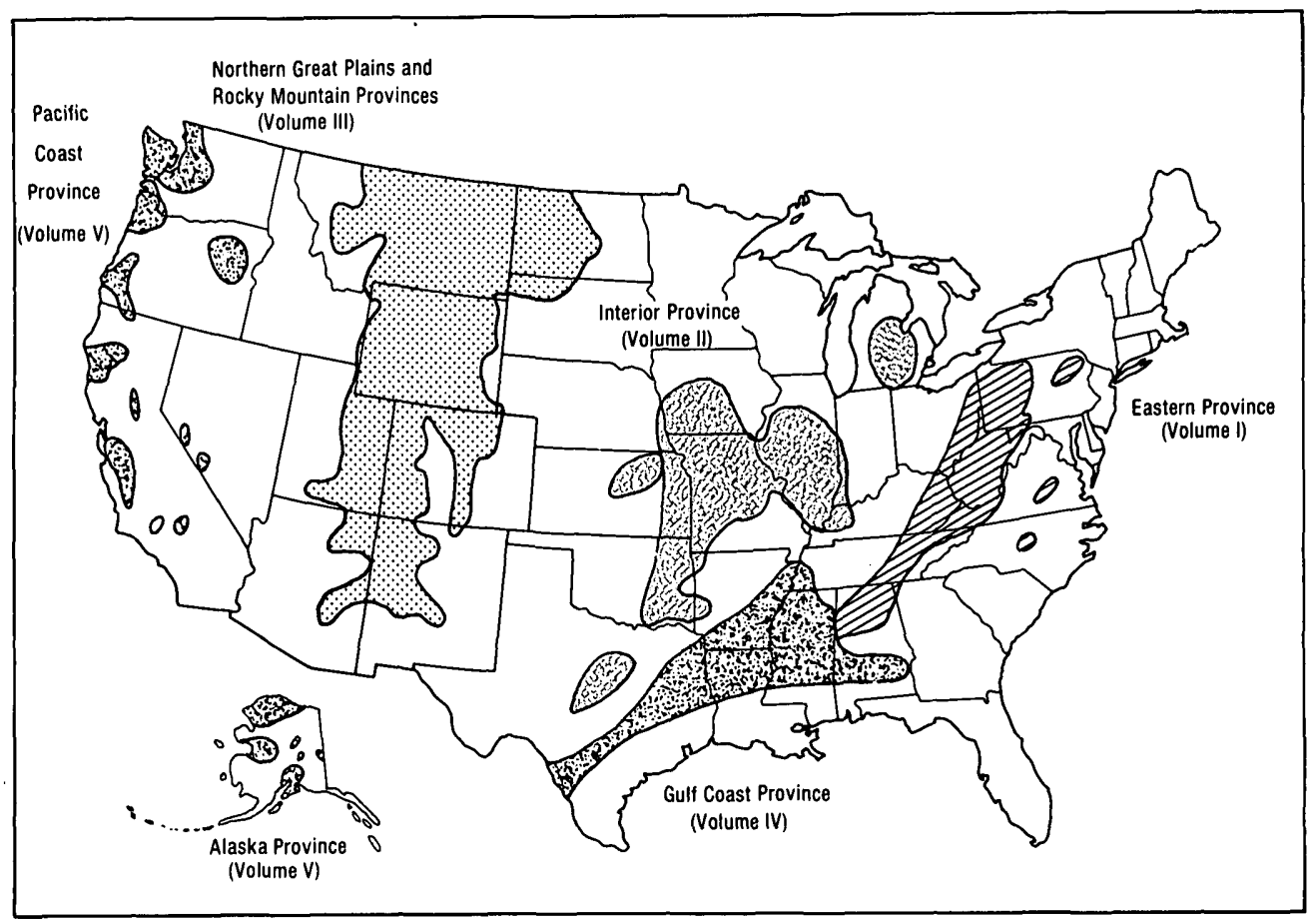

Figure 9.4-1 Index volumes and related provinces 
Adams, G. I., Butts, Charles, Stephenson, L. W., and Cooke, C. W., 1926, Geology of Alabama: Alabama Geological Survey Special Report 14, 312 p.

Bingham, R. H. 1979, Low-flow characteristics of Alabama streams: Alabama Geological Survey Bulletin 117, $39 \mathrm{p}$.

Buckman, H. O., and Brady, N. C., 1969, The nature and properties of soils ( $7 \mathrm{th}$ ed.): New York, MacMillan Company, $653 \mathrm{p}$.

Causey, L.V., Wahl, K.D., Jefferson, P.O., and Harris, W. F., Jr., 1972, Water availability and geology in Marion County, Alabama: Alabama Geological Survey Map 105, 31 p.

Cherry, Rodney N., 1963, Chemical quality of Alabama streams, 1960, a reconnaissance study: Alabama Geological Survey Information Series 27, 95 p.

Culbertson, W. C., 1964, Geology and coal resources of the coal-bearing rocks of Alabama: U.S. Geological Survey Bulletin 1182-B, 79 p.

Faust, R. J., and Harkins, J. R., 1980, Water availability of Blount County, Alabama: Alabama Geological Survey Map 141, 19 p.

Faust, R. J., and Jefferson, P. O., 1980, Geology and water availability of Cullman County, Alabama: Alabama Geological Survey Map 145, 30 p.

Fenneman, N. M., 1938, Physiography of eastern United States: New York, McGraw-Hill, 724 p.

Gamble, C. R., 1965, Magnitude and frequency of floods in Alabama: Alabama Highway Department, HPR 5, $42 \mathrm{p}$.

Hains, C. F., 1973, Floods in Alabama; magnitude and frequency: Alabama Highway Department, 39 p.

Hubbard, E. F., 1976, Sedimentation in Lake Tuscaloosa, Alabama: U.S. Geological Survey OpenFile Report 76-158, 35 p.

Johnston, W. D., Jr., 1930, Physical divisions of northern Alabama: Alabama Geological Survey Bulletin $38,48 \mathrm{p}$.

- - - - 1932, A revision of physical divisions of northern Alabama: Journal of the Washington Academy of Sciences, v. 22, no. 8 , p. 220-223.

-1933, Ground water in the Paleozoic rocks of northern Alabama: Alabama Geological Survey Special Report 16, pt. 1, 414 p.
Kaufman, M. I., and Dion, N. P., 1967, Chemical character of water in the Floridan aquifer in southern Peace River basin, Florida: Florida Board of Conservation, Division of Geology, and Southwest Florida Water Management District, Tallahassee, Map Series No. 27.

Kaufman, Matthew I., 1970, the pH of water in Florida streams and canals: Florida Department of Natural Resources, Bureau of Geology, Tallahassee, Map Series No. 37.

Kidd, J. T., 1976, Configuration of the top of the Pottsville Formation in west-central Alabama: Alabama Oil and Gas Board, Oil and Gas Map 1, 1 plate.

Knight, A. L., and Newton, J. G., 1977, Water and related problems in coal-mine areas of Alabama: U.S. Geological Survey Water-Resources Investigations 76-130, 51 p.

Mellen, F. F., 1947, Black Warrior basin, Alabama and Mississippi: American Association of Petroleum Geologists Bulletin, v. 31, no. 10, p. 1801-1816.

Mettee, M. F., Moser, P. H., and Dean, Lewis, 1978, Use of water in Alabama 1975, with projections to 2020: Alabama Geological Survey Information Series 48, 45 p.

McCalley, Henry, 1891, Report on the Coal Measures of the Plateau region of Alabama: Alabama Geological Survey Special Report 3, 238 p.

McGlamery, Winifred, 1955, Subsurface stratigraphy of northwest Alabama: Alabama Geological Survey Bulletin 64, 503 p.

Mining Information Series, 1978, Keystone coal industry manual: New York, 1265 p.

Murray, C. R., and Reeves, E. B., 1977, Estimated use of water in the United States in 1975: U.S. Geological Survey Circular 765, 39 p.

Olin, D. A., and Bingham, R. H., 1977, Flood frequency of small streams in Alabama: Alabama Highway Department, HPR 83, 44 p.

O'Rear, D. M., 1957, Water levels and artesian pressures in Alabama, 1955: Alabama Geological Survey Information Series 5, 49 p.

- 1960, Ground-water levels in Alabama in 1957 and 1958: Alabama Geological Survey Information Series 19, 81 p. 
O'Rear, D. M., and Knowles, D. B., 1955, Water levels and artesian pressures in Alabama, 1954: Alabama Geological Survey Information Series 2, 49 p.

--_-1957, Ground-water levels in Alabama in 1956: Alabama Geological Survey Information Series $11,46 \mathrm{p}$.

Peace, R. R., Jr., 1963, Geology and ground-water resources of Franklin County, Alabama, a reconnaissance: Alabama Geological Survey Bulletin 72, 55 p.

Peirce, L. B., 1954, Floods in Alabama, magnitude and frequency: U.S. Geological Survey Circular 342, $105 \mathrm{p}$.

Sapp, C. D., and Emplaincourt, Jaques, 1975, Physiographic regions of Alabama: Alabama Geological Survey Map 168.

Searcy, J. K., 1959, Flow-duration curves, manual of hydrology; Part 2, Low-flow techniques: U.S. Geological Survey Water-Supply Paper 1542-A, 33 p.

Semmes, D. R., 1929, Oil and gas in Alabama: Alabama Geological Survey Special Report 15, 408 p.

Scott, J. C., 1978, Drainage areas for the upper Black Warrior River basin, Alabama: Alabama Geological Survey Atlas Series 12, 157 p.

Shotts, R. Q., 1954, The identity and equivalency of persistent coal zones, sandstone beds and conglomerates of southern Tennessee and the Plateau region of Alabama, based upon a study of the literature: Alabama Academy of Science Journal, v. 26, p. $37-46$.
Stearns, R. G., and Mitchum, R. M., Jr., 1962, Pennsylvanian rocks of southern Appalachians in Pennsylvanian System in the United States-A symposium: Tulsa, Oklahoma, American Association of Petroleum Geologists, p. 74-96.

U.S. Army Corps of Engineers, 1972, Stream mileage tables with drainage areas: $165 \mathrm{p}$.

U.S. Department of Agriculture, 1974, General soil map, State of Alabama: Auburn, Alabama, Soil Conservation Service.

_-_-_1975, Soil associations of Alabama: Soil Conservation Service, Series No. 24.

U.S. Department of Commerce, 1961, Rainfall frequency atlas of the United States: Weather Bureau, Technical Paper No. 40, 115 p.

U.S. Department of the Interior, 1977, Guidelines for reclamation study areas: Bureau of Land Management, EMRIA Handbook, 1977, 83 p.

U.S. Environmental Protection Agency, 1977, National interim primary drinking water regulations: Environmental Protection Agency Report 570/9-76-003, $159 \mathrm{p}$.

Vestal, F. E., and Mellen, F. F., 1936, The coal of northern Alabama, report on a survey made for the Tennessee Valley Authority: Tennessee Valley Authority unpublished report, $90 \mathrm{p}$.

Wanless, H. R., 1946, Pennsylvanian geology of a part of the southern Appalachian coal field: Geological Society of America Memoir 13, 162 p. 


\section{Appendix 1. Stream Classification Alabama Intrastate Waters}

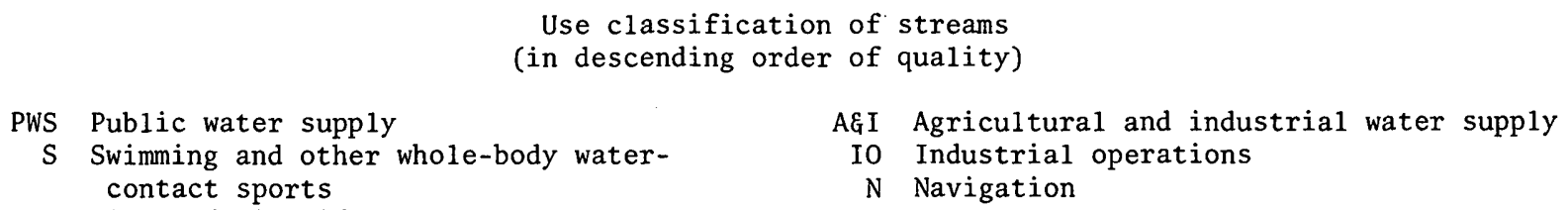

THE WATER RIVER BASIN

\begin{tabular}{|c|c|c|c|}
\hline$\underline{\text { Stream }}$ & From & To & Classification(s) \\
\hline Locust Fork & $\begin{array}{l}\text { County road between Hayden } \\
\text { and county line }\end{array}$ & $\begin{array}{l}\text { Junction of Slab and } \\
\text { Clear Creeks }\end{array}$ & F\&W \\
\hline Sipsey Fork & $\begin{array}{l}\text { Junction of Mulberry and } \\
\text { Sipsey Forks }\end{array}$ & Lewis Smith Dam & FWS/FEW \\
\hline Lake Lewis Smith on S & sey Fork & & $\mathrm{S} / \mathrm{F} \& W$ \\
\hline Sipsey Fork & Lake Lewis Smith & its source & FEW \\
\hline Little Warrior River & Locust Fork & $\begin{array}{l}\text { Junction of Blackburn } \\
\text { Fork and Calvert Prong }\end{array}$ & FE्षW \\
\hline Calvert Prong & Little Warrior River & $\begin{array}{l}\text { City of Oneonta's water } \\
\text { supply intake }\end{array}$ & F\&W \\
\hline Calvert Prong & $\begin{array}{l}\text { City of Oneonta's water } \\
\text { supply intake }\end{array}$ & its source & PWS \\
\hline B1ackburn Fork & Little Warrior River & Inland Lake Dam & F\&W \\
\hline Blackburn Fork & Inland Lake Dam & its source & PWS/S \\
\hline Chitwood Creek & Calvert Prong & $\begin{array}{l}\text { its source (jct. with } \\
\text { Mil1 \& Cheney Branch) }\end{array}$ & $\mathrm{F} \& W$ \\
\hline Mill Creek & Chitwood Creek & its source & $\mathrm{AE} \mathrm{I}$ \\
\hline Graves Creek & Locust Fork & its source & FEW \\
\hline Whippoorwill Creek & Locust Fork & its source & F\&W \\
\hline Clear Creek & Locust Fork & its source & F\&W \\
\hline Slab Creek & Locust Fork & Alabama Highway 75 & FEW \\
\hline Slab Creek & Alabama Highway 75 & its source & $A \& I$ \\
\hline Brogden River & Mulberry Fork & $\begin{array}{l}\text { Junction of Eightmile and } \\
\text { Brindley Creeks }\end{array}$ & $A E I$ \\
\hline Brindley Creek & Brogden River & its source & PWS \\
\hline Eightmile Creek & Brogden River & $\begin{array}{l}\text { Cullman water supply } \\
\text { reservoir dam }\end{array}$ & AEI \\
\hline
\end{tabular}


Appendix 1. Stream Classification Alabama Intrastate Waters (continued)

THE WARRIOR RIVER BÁSIN--Continued

Stream

Eightmile Creek

Pope Creek

Copeland Creek

Ryan Creek

Crooked Creek

Brushy Fork

Clear Creek

Clear Creek

Clifty Fork

Cane Creek

Cane Creek

Stream

Bear Creek

Cedar Creek

Little Bear Creek

(Franklin County)
From

Cullman water supply reservoir dam

Cullman water supply dam

Mulberry Fork

Lake Lewis Smith

Lake Lewis Smith

Lake Lewis Smith

Lake Lewis Smith

City of Haleyville water supply reservoir dam

Lake Lewis Smith

Sipsey Fork

Town of Double Springs water supply reservoir

dam
To

its source

its source

PWS

its source

F\&W

its source

F\&W

its source

its source

City of Haleyville water supply reservoir dam

its source

PWS

its source

F\&W

Town of Double Springs

water supply reservoir dam

its source

PWS

THE TENNESSEE RIVER BASIN

From

To
Alabama-Mississippi State line
Alabama-Mississippi State
line

its source*

its source*

Cedar Creek
F\&W

Classification(s)

F\&W

S/F\&W

* Reservoirs being constructed or planned for construction by the Tennessee Valley Authority (TVA) on Bear Creek, Cedar Creek, and Little Bear Creek are to be suitable for swimming and other whole-body water-contact sports or as future sources of public water supply. 


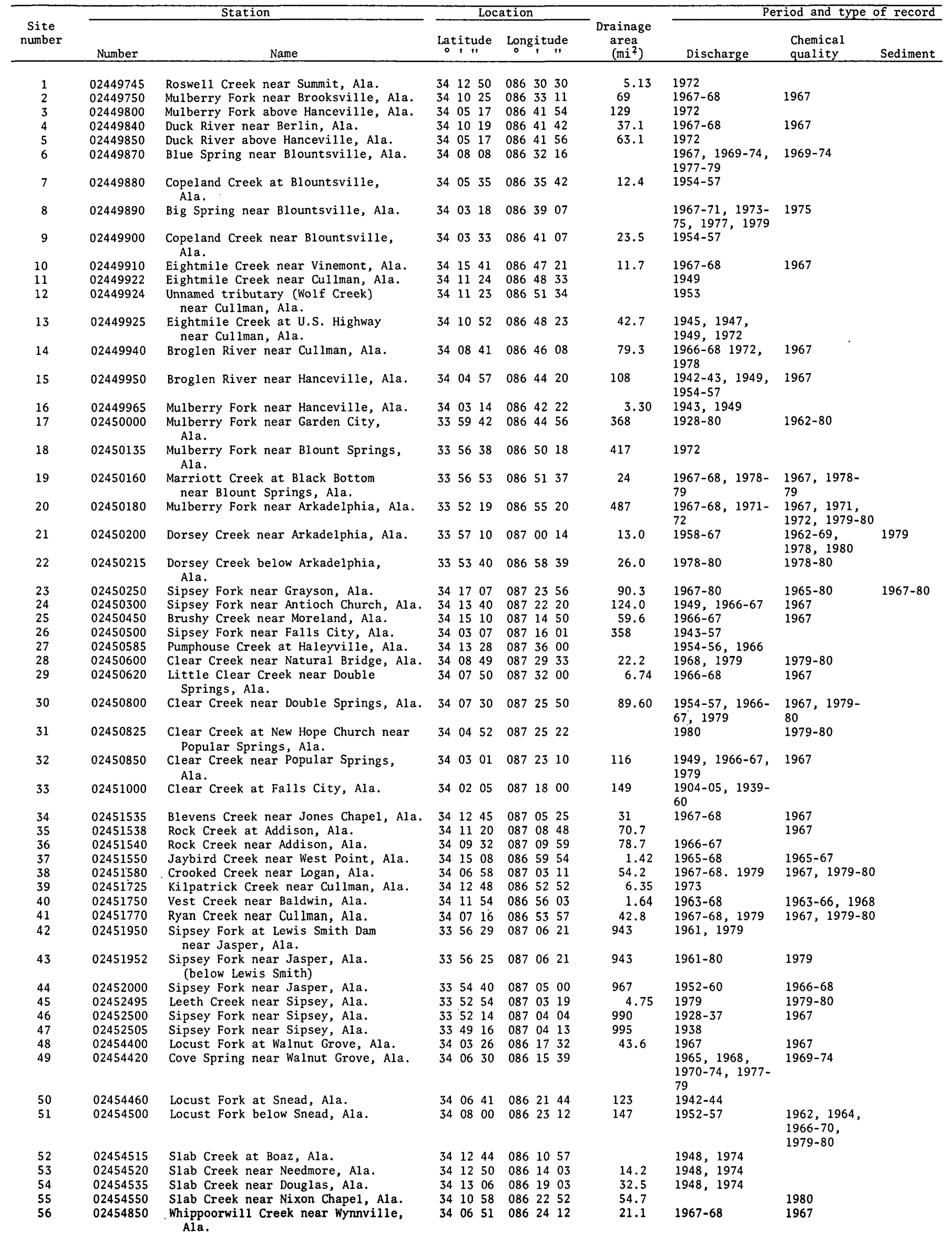


Appendix 2. Surface-water stations (continued)

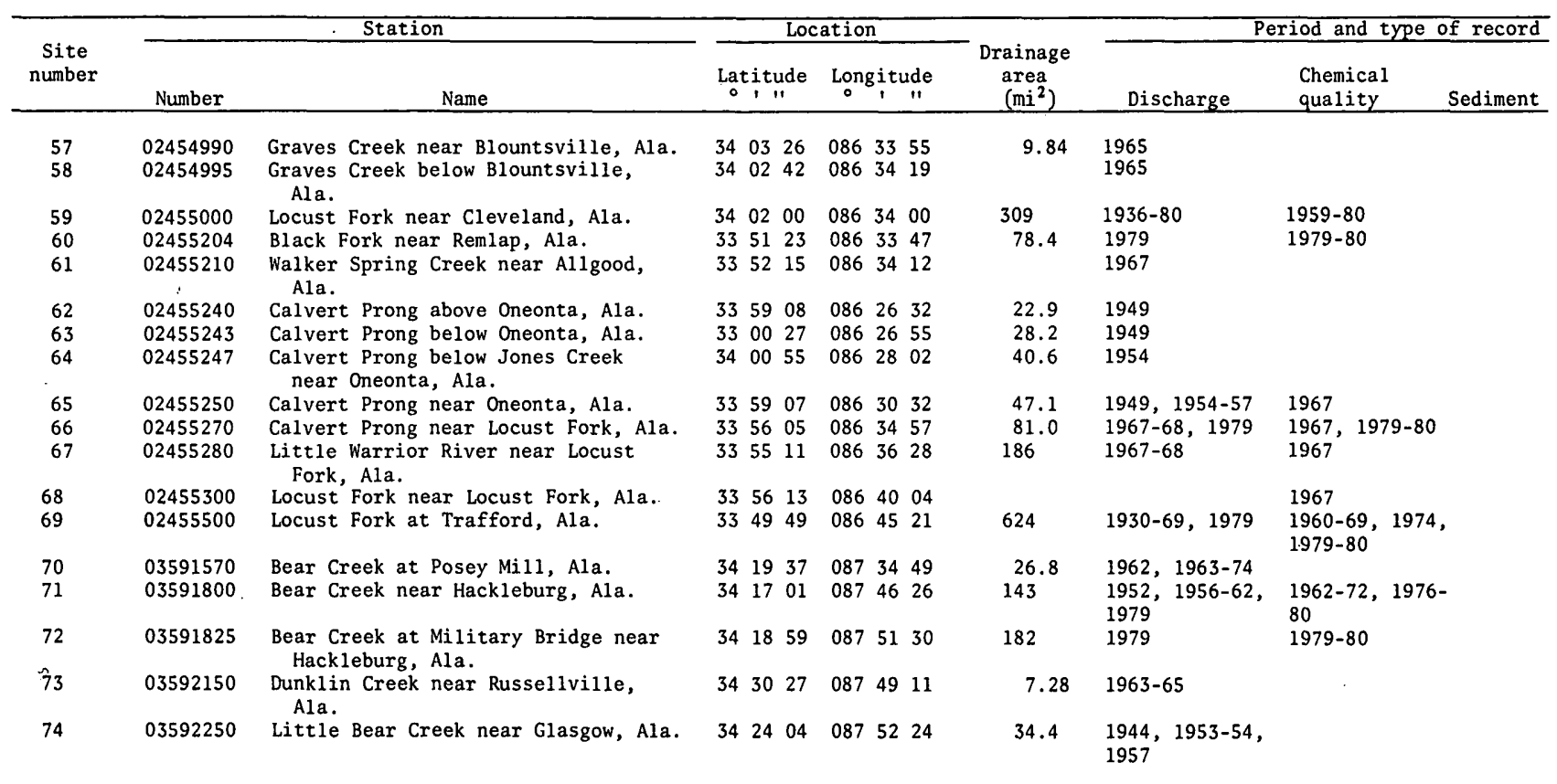


Appendix 3. Ground-water stations

Wells

\begin{tabular}{|c|c|c|c|c|c|}
\hline $\begin{array}{c}\text { Site } \\
\text { number } \\
\text { (fig. } 4 \cdot 2-1) \\
\end{array}$ & $\begin{array}{c}\text { Site } \\
\text { identification } \\
\text { number }\end{array}$ & County & $\begin{array}{l}\text { Local } \\
\text { number }\end{array}$ & Aquifer & Period of record \\
\hline 1 & 340628086151401 & Etowah & $\mathrm{H}-3$ & $\begin{array}{l}\text { Fort Payne Chert and } \\
\text { Maury Formation }\end{array}$ & $1960,1968-71,1973-80$ \\
\hline 2 & 340239086200401 & Blount & $G-3$ & $\begin{array}{l}\text { Copper Ridge Dolomite } \\
\text { and Chepultepec } \\
\text { Dolomite }\end{array}$ & $1968-69,1973-74,1976-78$ \\
\hline 3 & 335647086282101 & Blount & $\mathrm{P}-5$ & $\begin{array}{l}\text { Copper Ridge Dolomite } \\
\text { and Chepultepec } \\
\text { Dolomite }\end{array}$ & $1968-71,1973-80$ \\
\hline 4 & 340959086305901 & Blount & D-2 & $\begin{array}{l}\text { Fort Payne Chert, Tus- } \\
\text { cumbia Limestone, and } \\
\text { Maury Formation }\end{array}$ & $1966,1968-71,1973-80$ \\
\hline 5 & 341837086294301 & Marsha1l & Ma1-4 & $\begin{array}{l}\text { Sandstone of Potts- } \\
\text { ville Formation }\end{array}$ & \\
\hline 6 & 334914086443201 & Jefferson & B-1 & $\begin{array}{l}\text { Pottsville Forma- } \\
\text { tion }\end{array}$ & $1968-80$ \\
\hline 7 & 335823086453201 & Blount & $M-3$ & Bangor Limestone & $1966,1968-71,1973-80$ \\
\hline 8 & 341031086504301 & Cullman & Cul-1 & $\begin{array}{l}\text { Sandstone of Potts- } \\
\text { ville Formation }\end{array}$ & $1952-78^{*}$ \\
\hline 9 & 340821087214601 & Winston & $\mathrm{H}-9$ & $\begin{array}{l}\text { Sandstone of Potts- } \\
\text { ville Formation }\end{array}$ & $1965,1968-71,1973-80$ \\
\hline 10 & 341702087244001 & Winston & $\mathrm{C}-1$ & $\begin{array}{l}\text { Sand of Pottsville } \\
\text { Formation }\end{array}$ & $1965,1967-75$ \\
\hline 11 & 341644087294001 & Winston & D-1 & $\begin{array}{l}\text { Sand of Pottsville } \\
\text { Formation }\end{array}$ & $1965,1967-74$ \\
\hline 12 & 342137087311401 & Lawrence & $\mathrm{U}-2$ & $\begin{array}{l}\text { Sand of Pottsville } \\
\text { Formation }\end{array}$ & $1961,1967-74$ \\
\hline 13 & 343131087442801 & Franklin & Fra-1 & $\begin{array}{l}\text { Bangor Limestone and } \\
\text { sand and gravel of } \\
\text { Tuscaloosa Group }\end{array}$ & $1962-78 *$ \\
\hline
\end{tabular}

\begin{tabular}{|c|c|c|c|c|c|c|c|}
\hline $\begin{array}{c}\text { Site } \\
\text { number } \\
\text { (fig. } 4.2-1 \text { ) } \\
\end{array}$ & $\begin{array}{c}\text { Ground-water site } \\
\text { identification } \\
\text { number }\end{array}$ & $\begin{array}{c}\text { Surface water site } \\
\text { identification } \\
\text { number }\end{array}$ & County & $\begin{array}{l}\text { Local } \\
\text { number }\end{array}$ & Name of spring & Aquifer & Period of record \\
\hline 14 & 340808086321601 & 02449870 & Blount & D-5 & $\begin{array}{l}\text { Blue Spring near } \\
\text { Blountsville }\end{array}$ & Bangor Limestone & $1967,1969-74^{* *}, 1977-79$ \\
\hline 15 & 340318086385601 & 02449890 & Blount & $\mathrm{J}-4$ & $\begin{array}{l}\text { Big Spring near } \\
\text { Blountsville }\end{array}$ & Tuscumbia Limestone & $1967-71,1973-80$ \\
\hline 16 & 340630086153901 & 02454420 & Etowah & $\mathrm{H}-25$ & $\begin{array}{l}\text { Cove Spring near } \\
\text { Walnut Grove }\end{array}$ & Bangor Limestone & $\begin{array}{l}1964,1968,1969-74 * * \text {, } \\
1976-80\end{array}$ \\
\hline 17 & 335215086341201 & 02455210 & Blount & $\mathrm{T}-2$ & $\begin{array}{l}\text { Walker Spring near } \\
\text { Allgood }\end{array}$ & $\begin{array}{l}\text { Chepultepec Dolomite } \\
\text { Copper Ridge Dolomite }\end{array}$ & $1966-67$ \\
\hline
\end{tabular}

* Continuous recording of water-level for period of record.

* * Continuous record of discharge. 